Министерство образования и науки Российской Федерации Северо-Восточный федеральный университет имени М.К. Аммосова

\author{
П.В. Максимова, Л.П. Григорьева
}

\title{
КОМПОЗИЦИОННЫЙ АНАЛИЗ ПОЭМЫ (на материале якутской литературы)
}

\author{
Учебное пособие \\ 2-е издание, дополненное
}

\begin{abstract}
Рекомендовано ГОУ ВПО «Московский педагогический
государственный университет» в качестве учебного пособия для студентов высших учебных заведений, обучающихся по специальности 031001 - Филология (специализация 031001.02 - Языки и литература народов России
\end{abstract}

(якутский язык и литература))

Якутск

2014 
УДК 82.0:801.6 82-1/-9 (571.56)

ББК 83.3 (2Рос=Як)

M15

Утверждено учебно-методическим советом университета

\section{Рецензенты:}

A.B. Оконешникова, к.п.н., доцент кафедры начального образования ПИ СВФУ; М.Н. Дьячковская, к.филол.н., с.н.с. сектора литературы ИГИиПМНС СО РАН

\section{Ответственный редактор}

П.В. Максимова, д.филол.н.

\section{Максимова, П.В.}

Композиционный анализ поэмы (на материале якутской литературы) : учебное пособие [электронное издание] / П.В. Максимова, Л.П. Григорьева. - 2-е изд., доп. - Якутск : Издательский дом СВФУ, 2014. - 106 с.

\section{ISBN 978-5-7513-1960-1}

В учебном пособии представлен композиционный анализ поэм различных типов. Приемы и методы анализа художественных текстов основываются на принцииах современных литературоведческих исследований. Это дает возможность на практическом материале ознакомить студентов, наряду с классическими учебниками по теории литературы, с новыми трудами известных российских литературоведов. В учебном пособии находят отражение такие проблемы, как вопросы авторского стиля, виды и формы композиционной структуры произведений, своеобразие стиха. Раскрываются национальные особенности якутской классической поэмы, основанные на связи литературы с фольклорной поэтикой.

Учебное пособие адресовано студентам, аспирантам, преподавателям.

УДК 82.0:801.6 82-1/-9 (571.56)

ББК $83.3(2 \mathrm{Poc}=$ Як)

(C) Якутский государственный университет, 2009

ISBN 978-5-7513-1960-1

(C) Северо-Восточный федеральный университет, 2014 (C) Максимова П.В., Григорьева Л.П., 2014 


\section{ОГЛАВЛЕНИЕ}

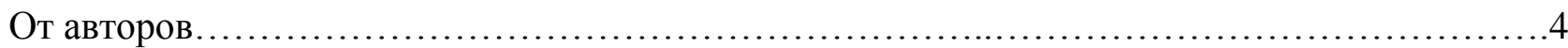

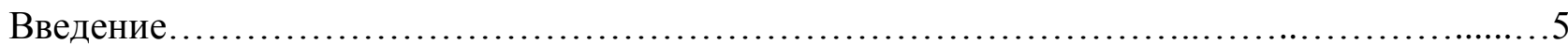

\section{І глава. Поэмы А.Е. Кулаковского}

1.1. Поэмное начало в литературном наследии основоположника якутской литературы. Обзор.

1.2. Композиционные особенности поэм А.Е. Кулаковского.

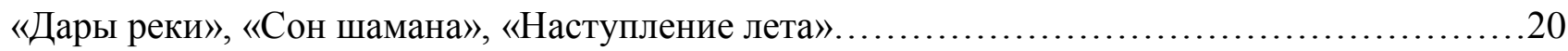

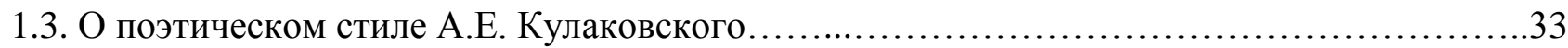

\section{ІІ глава. Поэмы А.И. Софронова}

2.1. Авторский дискурс и композиционные мотивы......................................41

2.2. Композиционные особенности лирических поэм А.И.Софронова.

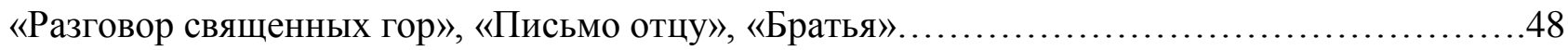

\section{ІІІ глава. Поэмы П.А. Ойунского}

3.1. Жанровые особенности драматической поэмы........................................55

3.2. Композиционные особенности драматической поэмы

П.А. Ойунского «Красный Шаман». ...

3.3. Особенности композиционной структуры драматической поэмы

П.А Ойунского «Туйаарыма Куо Светлолицая». ...

\section{IV глава. Композиционный анализ драматических поэм}

4.1. Особенности композиционной структуры поэмы

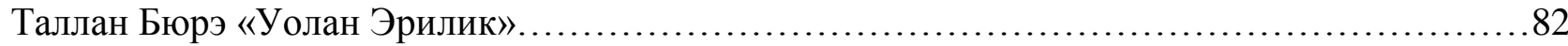

4.2. Функции авторских ремарок в поэме «Возвращение» М. Тимофеева......................91

4.3. Особенности композиции драматической поэмы

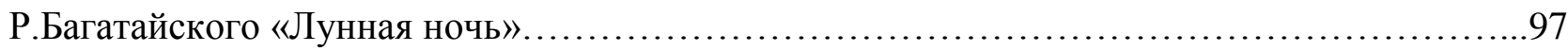




\section{OT АВТОРОВ}

Цель и задачи данного учебного пособия заключаются в стремлении представить пути и методы литературоведческого анализа художественного текста на нескольких последовательных уровнях, что повышает, на наш взгляд, личный профессиональный интерес студента к классическим произведениям. К ним в национальных литературах прежде всего относится поэма, художественные истоки которой восходят к фольклору, а проблематика чаще всего связывается с актуальными темами словесности или значительными общественными идеями времени. Таким образом, у студентов в историкотеоретическом анализе поэмы появляется практическая возможность (и необходимость) изучить, можно сказать, полный срез духовной ситуации периода и увидеть его в единстве художественного метода и авторского стиля с выходами на межлитературные творческие связи и взаимодействия. В этом плане авторы по мере возможности старались представить в учебном пособии современные методы и приемы анализа поэтического текста, что отражается не только в содержании исследования, но и в продуманной систематизации контрольных вопросов и заданий для самостоятельной работы студентов.

Учебное пособие написано с учетом практической работы со студентами на спецкурсах по поэтике художественного текста (поэмы и лирической поэзии), а также спецсеминаров по истории якутской литературной критики. Авторы надеются, что работа будет полезна для студентов и аспирантов, изучающих историю якутской литературы, где с именами А.Е.Кулаковского, А.И.Софронова и П.А.Ойунского непосредственно связываются вопросы становления и развития национальной литературы первой трети XX века. Их поэтическое наследие заслуженно приравнивается к духовному богатству

народа как образцы художественного творчества, выдержавшие серьезные испытания временем.

В учебном пособии введение, первая и вторая главы написаны П.В.Максимовой, третья и четвертая главы - Л.П.Григорьевой. 


\section{ВВЕДЕНИЕ}

В наше время по отношению к эстетике писателя чаще всего принято рассуждать о художественной концепции мира или модели мира как о понятии духовного начала в творчестве. В этом плане для национальной литературы источником самобытности, «вечно живой архаикой» (М.М.Бахтин) выступает фольклор. Его поэтика по отношению к миру образа представляет чаще всего эпическое начало так же, как и по отношению к структуре произведения или авторской концепции мира. В поэмах авторское «я» имеет определяющее значение как образ-переживание, раскрывающий ту или иную тему в большей части в эпическом ключе, ибо само по себе понятие «поэма» представляет собой синтетическое жанровое и структурное образование.

Якутская поэма отличается усложненной, разнообразной природой взаимодействия родовых начал, что предполагает многотипность художественной структуры жанра, когда «синтез на основе эпоса и синтез на основе лирики дают разные типы поэм» ${ }^{1}$. В художественной структуре отдельного произведения основным типообразующим компонентом является наличие или отсутствие сюжета, развивающегося конфликта. Отсюда лирические поэмы (условно назовем их первым основным типом) принципиально отличаются от поэм эпических и драматических, вместе взятых (также условно отнесем их ко второму основному типу). То есть структура жанра определяется классическим соотношением лирики, эпоса и драмы в литературе вообще. Здесь принимаются во внимание такие отличительные качества лирических поэм, как «необходимость фабульной основы», «тяготение к выразительному образу» ${ }^{2}$, тогда как фабула и развивающийся конфликт необходимы в эпических и драматических поэмах.

В поэмах с лирической доминантой обнаруживается публицистическая ориентация пафоса или философское движение мысли лирического героя, которое образно реализуется поэтами чаще всего в психологическом аспекте. В этом типе личностное ощущение исторического бытия выступает показателем способа раскрытия темы. С ним непосредственно связана композиционная структура поэмы. Это открытое выражение авторской концепции, своеобразное перемежение времени в художественном отображении действительности; концентрация лирического переживания вокруг одной конкретной социальноисторической или социально-нравственной проблемы. Авторское «я» в

\footnotetext{
${ }^{1}$ Числов М.М. Время зрелости - пора поэмы. - М., 1986. - С. 26.

${ }^{2}$ Кожинов В.В. К проблеме литературных родов и жанров // Теория литературы. Основные проблемы в историческом освещении. Роды и жанры. - М., 1964. - С. 44.
} 
лирических поэмах является, таким образом, понятием общественноисторическим: оно выражает гражданскую позицию не только отдельной личности, а стремление целого поколения, является определением идейноэстетической значимости отраженного в произведении времени и поставленной перед автором проблемы. В иных случаях лирическое «я» может выступить непосредственным носителем авторских настроений и идей. В таких поэмах размышления лирического героя представляют аналитический подход к явлениям действительности и содержат чаще всего или психологическую характеристику человека конкретного времени, или философскую оценку события или факта жизни. Таким образом, здесь наблюдается лирическая типизация объективно-эпического материала, что не позволяет в общем и целом отрицать присутствия эпического критерия в произведениях данной типологической группы.

В поэмах с эпической доминантой господство повествовательного начала проявляется в раскрытии темы во временной протяженности, что вытекает из основной черты эпоса, развернутого изображения человеческих характеров. Лирическое начало выступает здесь в виде эмоциональной оценки, размышления, личного воспоминания, прерывающих ход повествования; пейзажных зарисовок, тесно связанных с развитием темы произведения. Композиционная структура поэм этого типа определяется сюжетноповествовательным планом произведений, наличием развивающегося конфликта, не исключающего крупномасштабность, символику поэтического мышления.

Характерной особенностью эпических поэм выступает их «драматическое ответвление». Жанровая близость современной стихотворной драмы к поэме определяется напряженностью развития конфликта, усилением философского подтекста содержания, что приводит к преобладанию эпического, объективноисторического начала, внешне исключающего присутствие образа лирического героя.

Специфической особенностью и потенциальной возможностью эпической поэмы является большая свобода творческой связи автора с современным, историческим и фольклорным материалом. Обращаясь к современности, авторы поэм могут показать характер героя в становлении и развитии в широком нравственном и историческом контексте. Именно в поэмах этого типа авторы чаще всего обращаются к историческим темам, но историческое прошлое в их произведениях становится не столько само по себе предметом поэтического отображения, сколько реальным фактом, заключающим в себе начало живых событий дня. Отсюда в этих поэмах на первый план выдвигается эпическая и 
философская проблема: взаимопонимание людей разных эпох, диалектическая взаимосвязь поколений. И еще одним своеобразным видом поэм данного типа могут стать произведения с собственно национальным содержанием, в которых авторы обращаются к мифологическим сюжетам, традиционным фольклорным образам.

Таким образом, в эпических поэмах художественная типизация социально-исторических характеров осуществляется через сюжет, который не исключает присутствия авторского, лирического начала. В этом плане данное М.Бахтиным определение проблемы автора более всего подходит, на наш взгляд, к жанру поэмы. «Автор не только видит и знает все то, что видит и знает каждый герой в отдельности и все герои вместе, но и больше их, причем он видит и знает нечто такое, что им принципиально недоступно, и в этом всегда в определенном и устойчивом избытке видения и знания автора по отношению к каждому герою и находятся все моменты завершения целого - как у героев, так и совместного события их жизни, то есть целого произведения» ${ }^{3}$.

Подобная «эмоционально-волевая установка» автора выступает одной из основных жанрообразующих особенностей прежде всего в силу двойной родовой принадлежности поэмы. В этом заключается и суть проблемы «человек в поэме», с которой Л.Мелихова связывает специфику жанра: «Стихотворная речь в поэме - это залог взаимной неотделимости поэта и героя, залог невозможности полной его, героя, эмансипации. Стихотворная речь входит в задание поэмы, утверждая и подчеркивая отношение художника к герою как к своему творению» ${ }^{4}$. Двуединство героя и авторской личности в поэме предполагает и определение Г.Червяченко исторического пути развития поэмы, обуславливаемого «развитием человеческой личности и изменяющимся ее общественным положением» 5 .

Диахронное исследование жанра дает возможность рассмотрения его типологического разнообразия, то есть многомерности содержания художественных произведений, в котором заключается сущность жанра и его разновидностей. Имея в виду, что типологическое исследование учитывает не столько признаки явлений, сколько их взаимодействия в одном структурном единстве, и принимая за основные слагаемые общего понятия лирическое и эпическое начала в поэме, мы группируем материал указанной темы по однолинейному принципу классификации, а именно, по родовой доминанте.

\footnotetext{
${ }^{3}$ Бахтин М.М. Эстетика словесного творчества. - М., 1979. - С. 14.

${ }^{4}$ Мелихова Л.С. Человек в поэме // Проблемы теории и истории литературы. - М., 1971. - С. 191.

${ }^{5}$ Червяченко Г.А. Поэма в советской литературе. Закономерности развития и типология жанра: Дис. ... д-ра филол. наук. - Ростов н/Д., 1982. - С. 84.
} 
К поэмам с лирической доминантой мы относим лирико-публицистические и лирико-медитативные подтипы поэм; а к поэмам с эпической доминантой поэмы событийно-повествовательные и драматические. Таким образом, родовая природа жанра и воспроизведение значительных моментов жизни в аспекте их общественно-исторического бытия образуют координаты двухступенчатой внутрижанровой типологии. Вторая ступень классификации в первом основном типе представляет рассмотрение произведений со стороны их идейнотематической проблематики, характеризующей специфические особенности и закономерности лирики. А во втором основном типе дальнейшее разграничение произведений основано на способе воспроизведения внешнего по отношению к поэту мира. В данном случае повествовательная и драматическая формы изложения содержания - «не литературно-родовые различия», так как общим типологическим аспектом выступает именно, то что «в собственно родовом отношении эпос и драматургия тождественны и в одинаковой мере противостоят лирике» ${ }^{6}$. Избранный нами принцип классификации является рабочим и для нас удобен прежде всего тем, что подсказан объективным материалом исследования. Ибо данный принцип классификации, заключающий в себе элементы сопоставительного анализа выведенных типологических групп, основывается на стремлении уточнить социально-исторические закономерности развития рассматриваемого явления литературы, на выявлении поступательного движения в сторону художественно-стилевого и проблемно-тематического обогащения жанра в раскрытии образа и картины мира в тех или иных конкретных художественных произведениях.

В поэмах образное представление мира абсолютизирует именно авторское «я». Таким образом, художественная модель мира создается в них через образ Поэта, который в данном случае чаще всего равняется понятию не столько социальному, историческому, сколько началу духовному, вневременному, которое изначально стремится вырасти в характер, представляющий время или поколение в философском аспекте.

В данном учебном пособии рассматриваются композиционные особенности поэм, ставших для национальной литературы классическими. В этой связи следует отметить, что в 1940-50-е гг. насущной задачей для якутской поэзии стало преодоление риторики, декларативности, которое сопровождалось довольно напряженными спорами вокруг проблемы литературного наследия. Творчество А.Е. Кулаковского, А.И. Софронова, П.А. Ойунского в форме классической духовной идеи проходит через все этапы еe развития. Последующие поколения якутских писателей, выражая свое

\footnotetext{
${ }^{6}$ Поспелов Г.Н. Теория литературы. - М., 1978. - С. 113.
} 
отношение к их наследию (на взгляд современного исследователя), давали оценку своему собственному творчеству, представляя, главным образом, ограниченность общественно-исторической сущности эстетических требований конкретного периода. Так, якутская поэзия, начавшаяся с вершины А.Е. Кулаковского, сделала эту вершину духовным достоянием. Именно поэтому произведения первых якутских писателей представляют в учебном пособии основной материал исследования.

Композиционный анализ - практическое выявление художественного взаимодействия структурных компонентов - основывается на подтверждении понятия о целостности художественного произведения. В этом аспекте современные теоретические обоснования и выводы находим в исследованиях M.M. Гиршмана: «Художественное произведение в своей полноте «событийно» именно потому, что оно представляет собою каждый раз снова и снова осуществляемое событие создания - созерцания - понимания художественной целостности: «образа мира, в слове явленного» (Б. Пастернак). Это не готовый мир и не готовый, раз и навсегда воплощенный и доступный для потребеления смысл, а форма непрестанного человеческого общения и порождения в нем поисков смысла. ... Произведение как художественная целостность - ... это орган формирования человеческого созерцания и понимания, человеческой мысли и чувства в их первоначальном единстве, саморазвивающемся обособлении» ${ }^{7}$.

Главный смысл конкретного произведения реализуется в динамическом единстве темы, идеи и формы, которое может воплощаться в каждом произведении по-разному. В этом проявляется самобытность и индивидуальное творческое начало в авторском варианте, что непосредственно отражается на совеобразии композиции произведения. Таким образом, необходимость выявления и анализа различных аспектов композиции в крупных поэтических произведениях - проблема сложная, что подтверждается многогранностью поисков и возможных решений, прежде всего учитывающих типологические характерности проивзедений. Особенности композиции непосредственно «диктуются» тематическим ракурсом произведения, представляющим эстетическую основу художественного мира, определяющим точку зрения авторского начала. В истории якутской литературы наглядным и поучительным примером в этом плане выступают различные редакторские «опыты вмешательства» в композиционном раскладе поэмы «Сон шамана» в изданиях 1946 и 1978 годов. На примерах анализа других поэма А.Е. Кулаковского можно представить особенности пространственных и временных соотношений в

\footnotetext{
${ }^{7}$ Гиршман М.М. Литературное произведение. Теория художественной целостности. - М., 2007. - С. 54-55.
} 
организации предметного мира в описательной поэзии и в философских размышлениях о социально-исторических проблемах общества, где «движущаяся в пространстве точка зрения» автора организует структурные компоненты произведения в единое художественное целое.

Диалогическое со- или противопоставления в поэмах ракрывают также сложный внутренний конфликт лирического «я». Именно эти приемы композиции могут явиться логической основой художественного воплощения «организующих принципов подобия противоположностей» (М.М. Гиршман) в конкретных поэтических картинах объективного мира. В композиционном анализе поэмы особое значение имеют своеобразие и вариации строфики и в целом ритмические характерности произведений. В этом аспекте в учебном пособии рассматриваются образные функции аллитерации как одного из самобытных национыльных параметров якутского стиха, а также стиховые повторы и парные объединения как примеры смысловой акцентуации строк.

В драматических поэмах система образов и художественная символика связываются с определенными общественно-историческими проблемами, отражающими противоречия эпохи. Отсюда крупномасштабность поэтического мышления, глубина и объемность идеи входят в «жанровую природу» этих произведений наравне с их стихотворной формой. В них композиционные функции контраста непосредственно связываются с противоборствующими в идеях образами, в каждом из которых присутствует лирическое начало, подчеркивающее решающую роль авторской концепции мира и человека. В этом плане строго регламентированное «присутствие автора» в ремарках выполняет особые композиционные функции.

В данном учебном пособии для студентов филологических вузов и аспирантов представлены примеры анализа разных типов поэм в истории якутской литературы в контексте обобщения идей современных литературоведческих исследований. В анализе композиционной структуры поэмы находят отражение такие проблемы, как своеобразие авторского стиля, роль и функции художественно-выразительных средств, системы поэтических образов, связанные с жанровыми особенностями конкретных произведений. 


\section{І глава. ПОЭМЫ А.Е. КУЛАКОВСКОГО}

\section{1. Поэмное начало в литературном наследии основоположника якутской литературы. Обзор}

В работах, посвященных изучению жизни и деятельности А.Е. Кулаковского (1877-1926) наблюдается одно общее положение: каждый автор непременно цитирует П.А. Ойунского, который в далеком 1926 году в прощальном слове Поэту наметил принципиальные направления в изучении его личности и творчества, подчеркнув основополагающее значение Кулаковского в истории народа. Это, во-первых, его реальный высокий авторитет как писателя и мыслителя. Во-вторых, признание его художественного творчества началом якутской литературы. В-третьих, непреходящее значение «эпохи Кулаковского» в духовной культуре народа ${ }^{8}$.

Уникально научное наследие классика. Им обработаны и систематизированы ценнейшие источники для изучения верования якутов, народные легенды и предания историко-этнографического плана. Особое значение имеют работы по якутскому языку и фольклору. Специальные исследования вопросов литературоведения, естествознания, социологии и практического народного хозяйства отличаются четкостью выводов и положений, что доказывает масштабные научные познания А.Е. Кулаковского. Сегодня, обращаясь к его историко-философскому научному наследию, можно находить прямые исчерпывающие ответы на многие проблемы современной жизни. Аналитические способности ученого, высокое чувство долга перед своим народом и своим историческим временем явились основой поистине классических трудов. Такие его работы, как «Вправе ли русские гордиться своим именем?» (1897), «Главнейшие достоинства поэзии Пушкина» (1987), «Якутской интеллигенции» (1912), «Якутские пословицы и поговорки» (1925), цикл статей по проблемам якутского языка (1921-1925), посвящены изучению словесности от фольклора до основных аспектов поэтики в живом современном их понимании. Эти труды охватывают социально-экономические проблемы начала века от агротехнических и технологических вопросов по землепользованию и скотоводству до социально-философских проблем интеграции стран в мировом экономическом пространстве. А.Е. Кулаковский в своих научных трудах положил начало изучению историографии народа саха и особенностей его самобытного верования (1914-1926). Уникальными

\footnotetext{
${ }^{8}$ Ойунский П.А. Бырастыы! // Кыым. 1926. 18 июня.
} 
материалами по естествознанию являются научная классификация видов животного и растительного мира Якутии (1917-1919).

Многогранная деятельность А.Е. Кулаковского - Поэта и Философа пронизана светлой любовью к родному народу. Он всю свою жизнь посвятил служению во благо народа саха, которым поистине гордился, преклонялся перед ним. Подчеркивая, что якутское верование развивалось по общему ходу эволюции естественных религий, он пишет: «Характерной чертой якутской религии была утилитарная и материалистическая точка зрения. Двойственность сил природы выражена в ней довольно ярко, но без резких переходов. ... Нам, нынешним якутам, остается только удивляться - как могла создаться у такого незначительного народца, каковыми являлись наши предки, - такая религия высокого развития» ${ }^{9}$.

Систематизировав около полутора тысяч единиц пословиц и поговорок, он констатирует, что каждый пожилой якут знает 90 \% «вошедшего в сей сборник» и активно использует в своей речи эти глубоко философские и меткие образные изречения [Научные труды, - С. 106].

Составив словарь заимствований из русского и иностранных языков в количестве около двух с половиной тысяч единиц самостоятельных, а не производных корней слов, он убеждается, что якуты переняли «не только названия новых предметов и культурных понятий, но и слова выражающие действия и качество их». Он далее удивляется, что «они перенимали и наречия, без которых могли бы прекрасно обойтись, и такие слова, которые на своем языке существуют». Учитывая, что «якутский язык сам по себе замечательно богат», делает вывод: «По всему этому факт перенятия якутами такого огромного количества русских слов можно объяснить исключительно лишь восприимчивостью и способностью якутов» [там же. - С. 321].

В трактате о «Правилах якутского стихосложения» он утверждает: «Аллитерацией писали в Древней Греции и Риме, а в особенности древнегерманские народы. Но аллитерация якутских стихов более усовершенствованная, так как заключает в себе не по одной гласной или согласной, а по целому слогу и простирается не две-три строчки, а на 10-20 строк» [там же. С. 452].

Ответственность перед народом пронизывает все художественное и научное наследие А.Е. Кулаковского. И действительно, «историческое значение «эпохи Кулаковского» состоит в том, что его творчество предстает как необычайно крупное, сложное, но внутренне цельное культурное и общественное явление в истории Якутии начала XX века». «Его деятельность

\footnotetext{
${ }^{9}$ Кулаковский А.Е. Научные труды. - Якутск. 1979. - С. 9.
} 
была устремлена в будущее, пронизана идеями и мыслями преобразований, утверждала все то лучшее, что было тогда в жизни и в людях» ${ }^{10}$.

Поэтические произведения А.Е. Кулаковского стали вершиной литературы народа саха. Его меткая сатира, проникновенная лирика, концептуальная философская поэзия охватывают идеи и проблемы своего времени, начиная от безобидно милых «портретов городских девушек» кончая сугубо государственными проблемами не только начала, но и всего XX века. В творческом пути А.Е. Кулаковского как классика литературы подтверждается последовательность народной философии, своеобразие его эстетических воззрений, художественная значимость его самобытной словесности.

Таким образом, можно утвердить, что поэтическое наследие А.Е. Кулаковского - это вся якутская литература в ее истоках. Этот тезис раскрывается по трем основным теоретическим положениям литературы: в аспекте жанровой систематики произведений и особенностей проявления в них авторской позиции как эквивалента художественной проблематики, а также создания индивидуального авторского стиля, равного подтверждению общественной значимости труда писателя. Данная триада в обобщенном виде проявляется в том, что он положил основу традиции, которая в истории литературы начинается с жанров. Основная жанровая специфика его поэзии - поэмное начало, что выражается в эпической основе его творчества.

В поэзии Кулаковского в целом тропы, стиховая и строфическая организация произведений восходят к фольклорным истокам. Как литературные переложения жанров фольклорной поэзии воспринимаются такие произведения, как «Байанай алгыһа» («Благопожелание Байаная», 1900), «Бүлүүлүү үнкүү» («Танец по-вилюйски», 1905), «Былыргы саха андаБара» («Старинная якутская клятва», 1921). Здесь автор выступает талантливым сказителем, певцом, «природным якутом», вместе с молоком матери впитавшим верования и культовые обряды своего народа ${ }^{11}$. С другой стороны, такие произведения, как «Абааһы андаБара» («Клятва Демона», 1908), «Үрүйэ» («Ручей»), «Өрүс бэлэхтэрэ» («Дары реки», 1909), считаются созданными «по мотивам» или в качестве «вольного перевода» из русской классической поэзии.

Этот вопрос раскрывается в работах Н.В. Покатиловой в ракурсе проблемы «становление литературы». В творчестве А.Е. Кулаковского она различает два начала: а) «последовательную и систематическую опору на метрику традиционного стиха» как следование «автохтонной традиции»; б) «ориентацию на русскую поэзию в целом как на определенный тип

\footnotetext{
${ }^{10}$ Иванов В.Н.Кулаковский и время (вместо предисловия) // А.Е.Кулаковский и время. - М., 2003. - С. 4-5.

${ }^{11}$ Кулаковский А.Е. Научные труды. - Якутск, 1970. - С. 8.
} 
поэтического осмысления действительности, что вместе с тем не означает опоры на конкретный стих «чужой» иноязычной традиции», а представляет «парадигматическое представление о книжной поэзии вообще» 12 .

В художественном наследии Кулаковского фольклорная поэтика в жанровом аспекте не исключает, а наоборот подчеркивает самобытное художественное воспроизведение авторской идеи. Например, поэт обращается к духу-покровителю охотничьего промысла - Байанаю - в самом начале своей литературной деятельности. Он датирует это произведение 1900 годом и выражает свою надежду на удачу в будущем символами народного верования: угощением огня с алгысом, «счастливой белой ворожбой» - бросанием «түөрэх» и радостным восклицанием «Туску-уо!». В стихотворениях «Оттоку олук алгыһа» («Благословение среднего поколения», 1912), «Былыргылыы алгыс» («Благословение по-старинному», 1916) литературной доминантой выступает ярко выраженный публицистический пафос: поэт обращается к «среднему поколению» с призывом к просвещению, к развитию, и свои высокие гражданские чувства передает в форме благопожелания. Здесь обращение к молодому поколению - это выражение просветительской идеи поэтамыслителя, который в начале века ставит перед своим народом конкретные цели и задачи: а именно, стремиться быть признанным наравне с другими просвещенными народами «по всей Сибири обширной, по дальней ее дали». В другом произведении, более конкретно сохраняя обрядовую поэтику, автор раскрывает идею добра и представление о счастье и назначении человека в духе концептуальных принципов «правильного пути» в народном представлении ${ }^{13}$.

В стихотворениях «Чабырқах» («Скороговорка», 1912), «Билбит-көрбут» («Узнавший-увидевщий», 1924) авторские выводы об актуальных проблемах своего времени и закономерностях общественной жизни поэтически оформлены в иронические иносказания бытового характера, что соответствует природе фольклорного жанра скороговорки.

Поэтика многих произведений А.Е. Кулаковского близка к форме якутских народных песен. Детальное красочное описание внешности объекта изображения без прямых публицистических выводов и заключений о сути данного явления, характерное для песен-импровизаций, присуще таким произведениям, как «Саха дьахталларын мэтириэттэрэ» («Портреты якутских женщин», 1904), «Кэччэгэй баай» («Скупой богач», 1907), «Итирик бурсуй ырыата» («Песня пьяного буржуя», 1915), «Арыгы» (в переводе на русский

\footnotetext{
12 Покатилова Н.В. А.Е.Кулаковский - первопоэт якутской традиции // Кулаковский и время. - М., 2003. C. 140 .

${ }^{13}$ Бурцев А.А. Кулаковский как поэт-мыслитель // На крылатом коне. - Якутск, 1995. - С. 13.
} 
язык: «Оборотень», 1916). Авторская гражданская идея выступает в них антитезой созданным образам. Поэт раскрывает устои общества в духе социальной сатиры, ориентированной на реалистическую типизацию. Поэтому он создает именно «портреты» или описывает образ жизни нескольких подобных персонажей. В другом случае перед читателем предстает соответствующая социальному уровню создаваемого образа психологическая индивидуализация в форме монолога-самовосхваления («Песня пьяного буржуя»).

В жанровой форме народных песен о предметах домашнего обихода и песен-тойуков новеллического характера созданы такие произведения, как «Сүүһүн туолбут эмээхсин ырыата» («Песня столетней старухи», 1906), «Эр аһыыта» («Плач по умершему мужу», 1916), композиция которых построена в виде повествования о судьбе от первого лица. В этих произведениях авторское начало четко прослеживается в социальном обобщении образов и их судеб, представленных реальными картинами народной жизни. Из них «Плач по умершему мужу» - стихотворение, написанное в Бодайбо, - авторами «Истории якутской литературы» названо «новой жанровой формой», аналогичной ритуальным плачам русской фольклорной поэзии. Однако нам представляется более правомерным их же сопоставление жанровой специфики этого произведения с песнями олонхо ${ }^{14}$.

Типологически близки к ним произведения «Куорат кыргыттара» («Городские девушки», 1921), «Тыа дьахтара» («Деревенская женщина», 1922), где сюжет ведется от имени автора. Их жанровая особенность выражается прежде всего в создании социальной картины быта и нравов времени. Образы якутских женщин во всех названных произведениях А.Е. Кулаковский раскрывает в форме поэтической хроники жизни литературных персонажей. В них первоначальная жанровая поэтика народных песен перерастает в «поэтохронику», в чем акцентируется близость авторского начала как «систематизатора» в единую сюжетную линию художественных деталей в описании образов во временной протяженности. Таким образом, в произведениях А.Е. Кулаковского временные и пространственные представления составляют художественное единство. Авторское начало им придает конкретные эмоционально-ценностные ориентиры. То есть, эти произведения большой стихотворной формы хронотопичны. Следуя М.М. Бахтину, можно разделить в них хронотопы жизненного пути («Песня столетней старухи», «Эр аһыыта», «Тыа дьахтара»), хронотопы

14 ТобуроковН.Н., Сыромятников Г.С. и др. История якутской литературы. Середина ХIX-начало XX века. Якутск, 1993. - С.103. 
провинциального городка («Городские девушки») и добавить еще хронотопы социальных портретов («Портреты якутских женщин», «Скупой богач», «Песня пьяного буржуя»). Хронотопы в литературоведении определяются носителями не только сюжетообразующих начал, они являются и категориями, конкретизирующими художественно-смысловое значение образов: «Всякое вступление в сферу смыслов совершается только через ворота хронотопов» (М.M. Бахтин). Таким образом, наличие данного качества в художественных произведениях «способно придавать им философический характер, «выводить» словесную ткань на образ бытия как целого, на картину мира - даже если герои и повествователи не склонны к философствованию» ${ }^{15}$. В этом ракурсе философское и социальное начала в портретах, монологах-жизнеописаниях, в авторском представлении персонажей в названных произведениях А.Е. Кулаковского несут в себе истоки эпического повествования как родового начала в якутской литературе.

Размышления другого плана, а именно философского, через символические образы и метафорическое описание реального явления в стихотворениях «Кырасыабай кыыс» («Красивая девушка», 1910), «Хомус» предстают в форме фольклорных произведений лироэпического характера. Они представляют собой рассуждения поэта о высших ценностях жизни. Например, художественный образ красивой девушки А.Е. Кулаковский дает в духе и стиле песен олонхо. В якутском эпосе красивая девушка - это символ прекрасного на земле, и только достойный ее красоты становится богатырем Среднего мира, защитником племени Айыы. Также в олонхо главная героиня является дочерью мудрых почтенных родителей, даже родина красавицы особая, что обязательно подчеркивается специальным описанием природы. Во всем этом заключается глубокий смысл, строгая логическая система: народные сказители не только гордятся и восхищаются красотой, которую можно увидеть, они утверждают истину о том, что понятие прекрасного в его высшем проявлении многозначно. Таким образом, философия стихотворений А.Е. Кулаковского основана на понятиях нравственной чистоты и непреходящих ценностей, в божественном начале которых поэт видит гуманистическую идею спасения нации. Размышления писателя о вечном опираются на эстетические идеалы народа. В них он находит универсальное емкое решение проблемы в ракурсе национальных духовных ценностей.

Идея благородного служения народу проходит и через стихотворение «Ырыаһыт» («Певец»), которое было найдено в 1946 г. в рукописном фонде Института языка, литературы и истории в архивных материалах

\footnotetext{
${ }^{15}$ Хализев В.Е. Теория литературы. - М., 1999. - С. 214.
} 
А.Е. Кулаковского и впервые опубликовано в газете «Кыым». Дата создания стихотворения долгое время не была уточнена. Н.Н. Тобуроков приводит новые архивные данные, относящиеся к этому стихотворению: сообщение о том, что 15 сентября 1924 г. на вечере Общества «Саха омук» А.Е. Кулаковский прочитал свое стихотворение «Ырыаһыт» ${ }^{16}$. Отсюда можно предположить, что оно написано после 1923 г. В этом произведении создается образ поэта, предназначенного судьбой «очищать души священно-близких друзей, когда они будут согнуты под тяжестью черных дум», «когда они попадут в хитроумные дьявольские сети, станут между собой грызться и браниться» (перевод С. Поделкова). В стихотворении, предположительно датированном 1924 годом, современный читатель находит отражение реальных эпизодов жизни автора в годы революционного переустройства жизни и гражданской войны в Якутии.

К народным песням формы «хоһуйуу» восходит жанровая специфика произведений «Борокуот аал» («Пароход», 1910), «Көтөр аал» («Самолет»), «ОБонньор кэпсээнэ» («Рассказ старика»), «Хаар-муус дойду аармыйата» («Армия снежно-ледяной страны», 1925). В них поэтическая речь имитирует живое воспевание, сопровождающее создание образов реального предметного мира. Устойчивыми формами песен-импровизаций выступают здесь традиционные повторяющиеся существенные структурные единицы стиха, неусложненная композиция, открытое восхищение автора увиденным явлением.

Итак, в жанровом отношении художественное наследие А.Е.Кулаковского своей основой имеет фольклорную поэтику, которая находится в органической связи с индивидуальным стилем писателя. А поэмное начало этих произведений заключается в том, что они все без исключения имеют исходной авторской идеей наиболее главные традиционные проявления национального духовного и творческого опыта в тесном сочетании с актуальными проблемами народной жизни, исторического времени. В этом плане особое значение приобретают даты создания произведений. Надо полагать, и сам автор учитывал это обстоятельство: им указаны годы и место создания большинства произведений. Например, «Благопожелание Байаная» (1900. Амга) открывает его двухтомник прижизненного издания. «Скороговорка», в идейном ракурсе очень близкая к поэме «Сон шамана», датируется 1912 г. и может выступить подтверждением даты создания «главного» произведения поэта. В начале гражданской войны создается «Старинная якутская клятва».

Самобытный поэт А.Е. Кулаковский и в переводы из русской классической поэзии вносил собственное стилистическое начало. «Абааһы андаБара» («Клятва Демона», 1908), первое опубликованное в печати

\footnotetext{
${ }^{16}$ Тобуроков Н.Н. Изучение жизни и творчества А.Е.Кулаковского в вузе (на якут. яз.). - Якутск, 2001. - С. 5.
} 
произведение А.Е. Кулаковского, написано в стиле якутского эпического произведения. Элегия Н. Цыганова «Ручей» в вольном переводе, датированном 1924 г., также воспринимается произведением специфически национальным. Это самое задушевное, безысходно-печальное стихотворение Кулаковского одно из последних поэтических творений писателя, можно сказать, прощальная дума поэта - вносит в эпическую поэзию основоположника якутской литературы яркую лирическую струю, раскрывая в его классически строгом облике черты проницательно нежного, ранимого творческого человека. Поэт описывает «судьбу» чистого ручейка среди зеленого поля и сопоставляет собственную жизнь, полную одиночества и тоски, с его долей в сравнении с бескрайними морями, сильными водопадами иных земель, далеких краев. А вся эта гармония судьбы и природы в духе романтического раздвоения души просто и естественно сочетается с формальными традициями якутской лирической поэзии. Классический элегический дистих заменяется двойной или тройной строфической повторяемостью астрофических стихов, и утраченная поэтика оригинала восполняется приобретенной формой, отнюдь не чужеродной мотиву разочарования жизнью, которому свойственны такие моменты поэтической конструкции, как монотонные вариации аналогичных образных единиц. Такова, к примеру, заключительная часть стихотворения:

Аны мантан инньэ мин

Аан ийэ дайдыттан

Арахсыахпар диэри

Ангардас санаа-оноо

Аргыстанан хааллым.

Орто туруу дойдуттан

Уларыйыахпар диэри

Соботох сор-мун

Доқордонон хааллым.

Ытык ыраас дайдыттан

Ыыра ыраатыахпар диэри

Ытыыр-сонуур иккини

Ыксалаһан хааллым.
С этого времени

До разлучения

С милой Родиной

Только дума-тоска

Осталась мне спутницей жизни.

До отлучения

От Среднего мира

Одно горе-печаль

Осталось мне другом.

До вечного отдаления

От священной чистой страны

Только плач да уныние

В соседстве остались со мною.

(дословный перевод наш. - П.М.)

По этим произведениям, отмеченным самим автором как «вольные переводы», можно заключить, что А.Е. Кулаковский и в данном направлении творчества остается прежде всего национальным поэтом. Он не «пересаживал» живые деревья другой классики «с корнями и комьями их родной почвы» в якутскую поэзию, а обладал в высшей степени профессиональным умением прививать к ним суть и дух собственной художественной традиции. 


\section{Контрольные вопросы и задания}

1. Как соотносятся между собой тема, идея и проблематика в произведениях А.Е. Кулаковского? Подготовьте обоснованные ответы по двум произведениям (по выбору).

2. Почему проблематика является главным мотивом в исследованиях произведений А.Е. Кулаковского в середине XX века?

3. В каких параметрах особенно сильно проявляется фольклорная поэтика стихотворений основоположника якутской литературы (образы, тематика, тропы)?

4. В чем главное отличие стихотворений А.Е. Кулаковского по сравнению с произведениями предшествующих ему авторов (И.Е. Кулаковского, М. Андросовой-Ионовой, В.В. Никифорова)?

5. Какие особенности якутского стиха А.Е. Кулаковский выявляет в работе «Правила якутского стихосложения»? Подтвердите свои аргументы примерами из текстов его произведений.

\section{Упражнения и задания для СРС}

1. Докажите примерами близость поэтики А.Е.Кулаковского к фольклорным произведениям.

2. Определите социальный, философский, публицистический мотивы авторской идеи в отдельных произведениях А.Е.Кулаковского.

3. Сделайте сопоставительный анализ проблематики следующих произведений:

«Байанай алгыһа» - «Оттоку олук алгыһа» - «Былыргылыы алгыс»;

«Тыа дьахтара» - «Куорат кыргыттара»;

«Эр аһыыта» - «Итирик бурсуй ырыата»;

«Саха дьахталларын мэтириэтэ» - «Кырасыабай кыыс»;

«Ырыаһыт» - «Үрүйэ».

4. Проанализируйте на примерах хронотопы, формы и приемы психологизма в следующих произведениях: «Саха дьахталларын мэтириэттэрэ», «Куорат кыргыттара», «Сүүһүн туолбут эмээхсин ырыата».

5. Сравните вольные переводы А.Е. Кулаковского с текстами оригиналов. Кратко обоснуйте понятие «вольный перевод».

6. Сделайте сопоставительные анализы переводов произведений М.Ю. Лермонтова на якутский язык, выполненных Г.М. Васильевым и И. Арбитой, со стихотворением А.Е. Кулаковского «Абааһы андаБара».

\section{Литература}

1. Алексеев Е.Е. Өксөкүлээх Өлөксөй (А.Е. Кулаковскай) олоқун уонна айар үлэтин туһунан. - Якутск: Кн. изд-во, 1966.

2. Башарин Г.П. Три якутских реалиста-просветителя. - Якутск: Респ. общество «Книга», 1994.

3. Кулаковский А.Е. Научные труды. - Якутск: Якутское кн. изд-во, 1979.

4. Кулаковский А.Е. Якутской интеллигенции. - М.: «Арт-Флекс», 2002.

5. Кулаковский А.Е. и время. - М.: «Арт-Флекс», 2003.

6. Тобуроков Н.Н. Саха литературатын историята. - Якутск: Изд-во ЯГУ, 2001. 
7. Тобуроков Н.Н. Өксөкүлээх Өлөксөй олођун уонна айар үлэтин үрдүк үөрэх кыһатыгар үөрэтии. - Якутск: Изд-во ЯГУ, 2001.

8. Өксөкүлээх Өлөксөй XXI үйэ саБаланыытыгар. - Якутск: Бичик, 2002.

\section{2. Композиционные особенности поэм А.Е. Кулаковского. «Дары реки», «Сон шамана», «Наступление лета»}

Творчество А.Е. Кулаковского в целом представляет раздумья писателямыслителя о судьбе родного народа. В этом плане значительными являются его поэмы «Өрүс бэлэхтэрэ» («Дары реки», 1909) и «Ойуун түүлэ» («Сон шамана», 1910). Четко выраженное типологическое качество - эпичность этих произведений - обусловило не столько разностороннее поэтическое освоение исторического времени, сколько масштабность общей мысли автора, выдвинувшего актуальные проблемы современной ему общественной жизни народа и раскрывшего в художественных образах свое отношение к этим животрепещущим вопросам.

Сюжет и композиция поэмы «Дары реки» были навеяны стихотворением М.Ю. Лермонтова «Дары Терека» (1839). Однако проблематика и система образов в поэме А.Е. Кулаковского являются национально-самобытными. То, что образ Владычицы - Ледовитого моря в «Дарах реки» оказался «родственным» образу Каспий-моря, обнаруживает типологическую близость данных произведений на уровне сюжетных элементов и композиционной структуры, а вне этого конкретного факта - сопоставимость художественных явлений в истории различных национальных литератур. Название «Ледовитое море» в дословном переводе на якутский звучит «Муустаах муора». Таким образом, Бабушка-океаниха с ее Быком зимы, пристанищем жестокого АанДаана, распространяющего беду по всей стране, сеющего ужас по великой земле, - это авторское художественно-философское создание, восходящее к древним мифологическим представлениям народа саха. Фольклорные истоки имеет и река Лена, представленная в поэме А.Е. Кулаковского символом доброго, жизнеутверждающего начала. Благородный нрав реки подтверждает ее уважение к окружающим: названия всех 14 притоков сопровождаются величальным словом «хотун» - «Аллан хатын... Томпо хотун... Тыра хатын...». Лена покровительствует людям, живущим на ее берегах. Преклоняется перед величием Ледовитого океана. А в ответах и в заключительном монологе 
«Бабушки-океанихи» звучат самоуверенность, безграничная вера в свою силу, гордость, доходящая до уничижительного отношения ко всему:

Ишь, разболталась, девочка,

Дурочка,

Решившая жалкой каплей воды

Пополнить просторы славного океана,

Спорящего вечно с солнцем самим,

Громоздящего горы огромных льдин,

Холодом дышащего неустанно.

(Перевод В. Солоухина)

Таким образом, поэма «Дары реки» художественно воссоздает диалектическое противоречие, существующее в природе: единство и борьбу противоположностей. Поскольку литература есть форма общественного сознания, идею произведения можно определить как «противоборство... добра и зла, света и мрака» ${ }^{17}$. Но в диалоге реки Лены и Ледовитого океана, кроме указанного социального содержания, не менее четко и убедительно прослеживается и другой, более глубокий философский подтекст: выражается мудрость Матери-Природы, способной защищать себя от своего же создания человека. Ведь в словах Лены, благодетельницы людей, звучит и обида на них, «забывших правду, добрые нравы», «одичавших в азарте горячечном»:

Шустрое течение

Мальчика Бодайбо

Как хотят изменяют.

Охраняющие леса

Темные

Изрубили в щепки

Белые, как снежный сугроб.

Участились убийства

И преступления...

Вот что творится на бедной Лене.

(Перевод В. Солоухина)

И потому Бабушка-океаниха в своем извечном противоборстве с солнцем и человеком выступает не только жестокой, кровожадной, безудержной в своих капризных желаниях владычицей, перед которой преклоняется величавая, спокойная, добрая Лена-река, но и той единственной пока силой, которая необходима для обуздания ненасытную жажду двуногого приобрести, покорить, приспособить.

\footnotetext{
${ }^{17}$ Сыромятников Г.С. Идейно-эстетические истоки якутской литературы. - Якутск, 1973. - С. 30.
} 
А.Е. Кулаковский в философском осмыслении социальных явлений через образы-символы противопоставляет две силы, создавая поэтическую модель противостояния двух понятий. Эта модель будет развита далее в других его произведениях большой стихотворной формы: «Өй, сүрэх икки мөккүөрэ» («Спор между разумом и сердцем», 1912), «Төрүу илигиттэн түннэри төлкөлөппүт» («Обездоленный еще до рождения", 1913). Составной частью этой модели являются реалистическое, философское и поэтическое типы мышления, т.е. взаимодействие объективной предметности, символической условности, метафоричности, что специфично для поэмы как жанра. В названных произведениях главная роль отводится эпическим образам, в которых раскрывается авторская идея, основанная на обобщении явлений жизни. Это - специфика формирования нового жанра, генетической основой которого является родовая синкретичность. Эпическое начало выражается в произведениях А.Е. Кулаковского в осмыслении современности с позиций состояния мира и человека, в определенной событийности сюжета, развитие которого протекает объективно, без непосредственного вмешательства авторского «я». Драматическое начало находит отражение в диалогической или монологической композиции произведений. Характерен с этой точки зрения и конфликт, разворачивающийся как острое противоборство различных миропониманий, а также господство философской проблематики над событийностью. Например, в «Споре между разумом и сердцем» или в «Дарах реки» - это борьба двух идей, двух убеждений. Но в этих произведениях поэтическая роль слова заключена не в индивидуализации образов, а в их обобщении. Стихотворная речь, усиливая эмоциональную выразительность, выступает здесь показателем равенства двух противопоставленных убеждений, взаимоисключающих идей. Но разные голоса (однако не более двух) в поэмах - это скорее выражение сомнений одной личности, т.е. на самом деле это спор с самим собой. Таким образом, данная диалогическая форма заключает в себе и лирическое начало. О поэмах Кулаковского «Спор между разумом и сердцем», «Обездоленный еще до рождения» Г. Сыромятников и М. Пархоменко пишут следующее: «Конфликты здесь основаны на борьбе противоречивых чувств в душе лирического героя. ...Они уже связаны с представлениями о лучшем будущем..., авторский пафос — в призыве Сердца стремиться к жизни, заполненной важными делами» ${ }^{18}$.

Неотделимость поэта от созданных им образов прослеживается и в финалах поэм, где содержится вывод, определяющий исчерпанность сюжета и

${ }^{18}$ Пархоменко М., Сыромятников Г. А.Е.Кулаковский // Кулаковский А.Е. Песни якута. - М., 1977. - С.1112. 
выражающий главную идею произведения. Например, в «Дарах реки» последнее безоговорочное повеление (приговор) Ледовитого океана «заморозить в прах» всех жалеемых Леной «людей солнца», а саму ее заковать «на девять месяцев в стужу и мрак, под ледяную пургу, под густую шугу» - это кульминационный трагический вывод о жизни и времени, перекликающийся с философскими воззрениями автора. Другие указанные выше поэмы также заканчиваются соответствующими содержанию и проблематике произведений выводами. Например, «Обездоленный еще до рождения», «Спор между разумом и сердцем» завершаются наставлениями нравственного характера.

И наконец, если взять все названные поэмы в совокупности как типологическое единство и рассмотреть их языковую систему, то также проступает родовой синкретизм их жанровой структуры. Оттолкнемся от упрощенной схемы значений грамматических форм глагола и местоимения в жанровой природе стихотворных произведений. М.Н. Поляков устанавливает следующие координаты классификации: «Установка на адресанте ("я") придает доминирующее значение эмоциональной функции и является особенностью лирики; при установке на адресате ("ты") доминирует апеллятивная функция, свойственная драме; установка на контекст (познавательная функция) порождает эпос, его естественная форма — "он"»19.

Приложим это к поэмам: 1) установка на адресанта - «Обездоленный еще до рождения», «Спор между разумом и сердцем» (каждый монолог как части поэмы); 2) установка на слушающего - во всех поэмах; 3) установка на контекст - «Обездоленный еше до рождения», «Дары реки».

Каждое из названных произведений основоположника якутской литературы - это фрагмент действительности. В его поэзии, зарождавшейся в условиях особой литературной ситуации, можно увидеть сосуществование разных жанровых элементов, которые подлежали кристаллизации, установлению. Но остается тот неоспоримый исторический факт: якутская литература начиналась с поэзии, с классических поэм А.Е. Кулаковского, созданных на основе диалектического движения «философской, религиозной и поэтической мысли, закрепленной словом». «История литературы, в широком смысле этого слова, - это история общественной мысли», - писал А.Н. Веселовский. И далее у него читаем: «Если, как мне кажется, в истории литературы следует обратить особое внимание на поэзию, то сравнительный метод откроет ей в этой более тесной сфере совершенно новую задачу проследить, каким образом новое содержание жизни, этот элемент свободы, приливающий с каждым новым поколением, проникает старые образы, эти

${ }^{19}$ Поляков М.Н. Вопросы поэтики и художественной семантики. - М., 1987. - С. 239. 
формы необходимости, в которые неизбежно отливалось всякое предыдущее

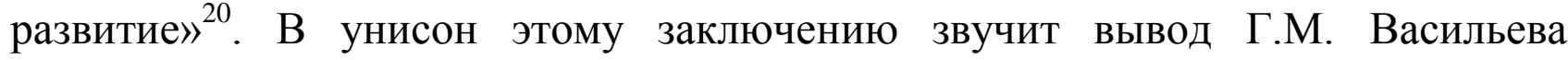
относительно поэзии А.Е. Кулаковского, который «явился убежденным преемником фольклорной поэтики, в частности фольклорного стихосложения». Исследователь подчеркнул, что именно он «развил и возвел в степень писаных правил народный аллитерационный стих» ${ }^{21}$.

При формировании якутской поэмы (в методологии литературоведения выступающей классическим жанром) освоение народной поэтики проявилось и в «чистом» виде. Фольклор как тип художественного сознания общества и как система образного мышления послужил непосредственной основой таких крупных поэтических произведений А.Е. Кулаковского, как «Сон шамана» и «Наступление лета».

Во всех исследованиях по творчеству Кулаковского, касающихся поэмы «Сон шамана», ${ }^{22}$ указываются социально-философская проблематика, эпическая масштабность, использование художественно-выразительных средств фольклора, прекрасный язык этого произведения, где наиболее полно выражены социальные и философские взгляды поэта с их достоинствами и спорными моментами. Однако шаман А.Е. Кулаковского не выступает только поэтическим двойником автора. Он является и непосредственным носителем народной философии, пророком, мессией, прозревающим мировое единство. Он выражает недовольство нарушениями обычаев предков охранять родную природу, свято беречь ее богатства; в народном духе звучит самоуничижение, когда он говорит о новых, непонятных ему явлениях общественной жизни.

Содержание произведения воспринимается как выступление шамана перед слушателями, присутствующими рядом с ним. Его обращение построено как система видений шамана, что определяет строгую композиционную структуру поэмы А.Е. Кулаковского. Своеобразную схему композиции дает В.Н. Протодьяконов в статье к четвертому изданию произведения (1994г.). Если во втором и третьем изданиях редакторы допускали нарушение фабульной системы канонического текста, то в данном издании поэма печатается в авторской редакции 1924 г.

В варианте композиционной разбивки «Сна шамана» В.Н. Протодьяконов находит семь частей, отражающих динамику авторской мысли в русле развития

${ }^{20}$ Веселовский А.Н. О методе и задачах истории литературы как науки (Вступительная лекция в курс истории всеобщей литературы, читанная в С-Петербургском университете 5 октября 1870 года) // Веселовский А.Н. Историческая поэтика. - М., 1989. - С.41.

${ }^{21}$ Васильев Г.М. Якутское стихосложение. - Якутск, 1965. - С. 57.

${ }^{22}$ Кулаковский: Сб.докл.к 85-летию со дня рождения. - Якутск, 1964; Окороков Г.Г. Концепция мира и человека в поэзии А.Е.Кулаковского: Автореф.дис.... канд.филол.наук -Якутск, 1971; Эрчимэн. Ексекюлэх вечно живой (на якут. яз.). - Якутск, 1995 и др. 
темы произведения: Вступление; 1. Человек и Природа; 2. Представление империализма, межнациональные отношения; 3. Классовое противостояние в Европе; 4. Мировая война и ее последствия; 5. Революция (гражданская война и ее завершение); 6. Переселение и его последствия; 7. Пути выживания нации; Заключение-Алгыс ${ }^{23}$.

На наш взгляд, поэма разделена самим автором на девять периодов вещего предсказания старца, что в тексте четко определено шаманским ритуальным припевом «Дом-ини-дом!» А шаман - этот «отстоявшийся в народной памяти готовый художественный образ, позволяющий преодолевать пространственные и временные дистанции», ${ }^{24}$ - представлен автором в данном случае в двух ипостасях. Сюжет поэмы построен как переменное чередование мифологического и реального художественного времени, и шаман выступает и как пророк, созданный поэтом в рамках народных традиций, и как реальный, размышляющий о своем конкретном историческом времени мудрый человек. Более того, мифологическое органически сливается с действительным историческим содержанием, не нарушает фабульной стройности, хроникальности сюжета поэмы в целом. Эту художественную целостность, образную красоту придает поэме единственный герой, безграничная эмоциональность, неповторимая самобытность которого и сами по себе становятся предметом поэтического осмысления, вытесняя порой реальный сюжет на второй план. В этом отношении мудрость и дальновидность А.Е. Кулаковского заключаются и в том, что он подтвердил последовательность и целостность народной философии в уникальном поэтическом персонаже образе шамана, гордо убеждающего вот уже несколько поколений «своих слушателей» в незыблемой закономерности развития общества. Поэт создал национальное эпическое произведение на фольклорной основе, потому что жанровым прототипом «Сна шамана» послужило конкретное явление устного народного творчества, связанное с культурой и верованиями саха, т.е. с принципами мировоззрения и философии народа как носителя части мировой цивилизации.

Композиция поэмы в более детальном рассмотрении может быть представлена следующим образом.

Вступление. Единственная «авторская строфа» в поэме, в которой говорится о времени создания произведения - начале века: «Ађыс сарданалаах / Аламай манан күн алаарыйа тахсан эрдэБинэ...» («Восьмилучевое из мглы /

${ }^{23}$ Протодьяконов В.Н. Ексекюлэх Алексей и «Сон шамана», Споры (на якут. яз.) // Кулаковский А.Е. Сон шамана. - Якутск, 1994. - С. 53.

${ }^{24}$ Пархоменко М., Сыромятников Г. Указ. работа. - С. 17. 
Величаво, ярое добела, / Вечное солнце, искрясь, / Восходило - в этот миг...» (пер. С. Поделкова)). Шаман - «Айыы-намыһын ойуун абақам...» («Белый шаман, жрец добрых божеств, не признающий над собою власти злых духов, одевался во все белое») - рассказывает свое видение в особый момент, а именно в начале века. Он, таким образом, отвечает на безмолвный вопрос народа, не без страха вступающего в новую эпоху: быть или не быть? что ожидает? Такое скупое на слово, емкое по содержанию вступление соответствует актуальной идее, необычному сюжету поэмы.

Первый период видения посвящен описанию социального кризиса как основной приметы переходного времени. Шаман раскрывает истоки и причины бедственного положения народов в экономически трудные периоды в жизни общества. Это глобальная экологическая проблема, связанная с проникновением цивилизации. Человек все более остро противопоставляется природе. И в поэме исходной проблемой ставится перенаселение, нехватка земель в развитых государствах.

Во втором периоде шаман описывает войны как последствия экономического кризиса стран. При этом он размышляет о колониальных войнах и мировой войне и видит в них своего рода стадии в историческом самоутверждении государств. Далее делает логический вывод о том, что именно войны между странами приводят к геополитическому противостоянию наций как субъектов человечества (мировой цивилизации).

Третий период раскрывает слушателям настоящее положение Якутии как части мирового единства (цивилизации). Поэт в образе шамана-провидца доводит до современников свои мысли о нелегкой судьбе малочисленного народа, населяющего огромное географическое пространство. В этой части проблема земли (территории) рассматривается с точки зрения интересов Америки, Японии и Китая в отношении Якутии.

В четвертом периоде видения раскрывается перед шаманом «блистательная сердцевина Земли», «высокое чело всей планеты» - Европа. В поэме убедительно точно, в красочных образах раскрывается глобальность европейского влияния на цивилизацию в целом в описании Англии как великой колониальной державы и Германии как центра европейской и мировой социально-политической мысли.

В пятом периоде шаман рассказывает о революционной ситуации, нарастающей $\mathrm{c}$ невиданной силой и угрожающей коренным переломом духовных и культурных устоев всего общества. Его видения заканчиваются следующими предсказаниями: «Урукку олох-куолу / уларыйар күнүгэр / уһун сордоох сут / улугурдуо буоллаБа./ Өбүгэ сақаттан үгэс / Үлтүрүйэр күнүгэр 
/ Өлүү-үлүгэр бөБө / Үтүрүйүө буоллаБа...» («Когда будут изменяться / прежняя жизнь и ее законы, / наступят долгая засуха / и голод. / Когда традиционные навыки предков / будут разбиваться вдребезги, / будут теснить людей / великая нужда, возможность гибели...») (Дословный перевод наш П.М.).

В шестом периоде шаман опять упоминает о духах войны: девице Идэмэр Кустуктай и парне Уот Солуонньай - и его вещие слова описывают страшную картину современной мировой войны, зловещий дух которой может запросто стереть с лица земли «сиротливый», доверчивый, бесконечно дорогой ему народ caxa.

В седьмом периоде в словах шамана звучит особое напряжение мыслей и чувств: он вещает о том, что мировая война перерастет в революцию и гражданскую войну. Наступают самые тяжелые моменты в состоянии старцапровидца: он предупреждает слушателей о том, что гражданская война по отношению к народу равна самоуничтожению. Драматизм «повествования» достигает здесь трагической кульминации, что автор передает и изменением ритмики поэмы. Развивая эту мысль, шаман представляет слушателям «новую партию» - «партию большевиков». В примечаниях к первому изданию А.Е. Кулаковский сделал следующее пояснение: «Когда в 1910 г. писалась мною эта песня, то предполагалось, что как всемирная война, так и русская революция разгорятся не ранее чем через 20-25 лет. Великий голод и переселение на отдаленные окраины должны были случиться тотчас вслед за войной и революцией как естественные их последствия. ... Все, что касается до партийных распрей внутри России, написано после революции» ${ }^{25}$.

Именно здесь, в дополнении (но включенном в основную часть поэмы), шаман предстает мудрым старцем, с болью в сердце констатирующим события, которые произошли после 1917г. Все эти явления истории он воспринимает вне политических и идеологических ситуаций: его переживания выражены в том же духе народных верований и носят общечеловеческий, гуманистический характер. А в целом это своеобразное «подведение итогов» перекликается с тем, о чем шаман размышлял в предшествующих частях поэмы. И его трагические предчувствия сменяются верой. Но надежда на будущее связывается с рассказом «о том, что наступит в мире потом». Предвидения шамана, связанные c деятельностью «первой партии», поэт дополняет мудрым советом «объединить помыслы многих - в один», предугадать «горе и нужды людей», а главное - «учения своего узко понятые места» исправлять, остерегаясь «пустопорожних слов» и умея «отступать чуток».

\footnotetext{
${ }^{25}$ Цит. по книге: Кулаковский А.Е. Ырыа-хоһоон (Стихи и поэмы). - Якутск, 1978. - С. 135.
} 
Восьмой и девятый периоды посвящены размышлениям о судьбе народа саха, перед которым жизнь ставит нелегкую проблему выживания в условиях сосуществования с многочисленным народом $\mathrm{c}$ развитой современной культурой и высоким уровнем образования.

Таким образом, в начальных четырех периодах видения шаман размышляет об экологических и социальных закономерностях цивилизации: обернувшись гигантским орлом, достигнув «вечных небес», обозревает «весь круг земной». Здесь проблема родной земли становится частью проблемы мирового единства стран и государств, где Якутия и Европа «сопоставляются» в ракурсе «края» (крайней, начальной точки) и «центра». С другой стороны, большая территория и малочисленность населения противопоставляются европейской проблеме нехватки земли. А в последующих периодах камлания мудрый шаман эту систему в виде всеобщего закона переносит на Российский регион и размышляет о судьбе нации в конкретных временных и пространственных масштабах. Отсюда его обращение-призыв к народу приобретает не только социально-исторический, но и философский смысл.

Тема произведения - размышления о судьбе народа саха в масштабах мировой цивилизации - раскрывается в форме логической спирали, где общественные закономерности развития государств представлены в виде целостной философской концепции. Концептуальной идеей-обобщением выступает и финал поэмы: трагическое предвидение будущего нации, усиленное в передаче экстаза шаманского камлания, завершается все же оптимистически, верой в лучшее будущее. Брошенная шаманом колотушка священного бубна (түөрэх) упала углублением вверх, «что предвещает удачу», и шаман крикнул обязательное в таких случаях счастливое слово «Тускуо!». Сам А.Е. Кулаковский подобное гадание назвал «самым общественным (т.е. распространенным в народе. - П.М.) в старину» ${ }^{26}$. А в целом все это высказывается шаманом с целью зародить в душе слушателей широкую цепь эмоционально-оценочных ассоциативных размышлений о времени и о себе, выводы из которых ни в коем случае не могут быть сведены к однозначному определению. Данная особенность содержания и идеи произведения художественное объединение в одно целое национального, исторического и философского начал - с течением времени не утрачивают своего значения. И «слушателями» шамана А.Е. Кулаковского являются вот уже несколько поколений якутских читателей, которые, воспринимая его предсказания поразному, соглашаясь и споря с ним, непременно проникаются к нему уважением и восхищением.

\footnotetext{
${ }^{26}$ Кулаковский А.Е. Научные труды. - Якутск, 1979. - С. 79-80.
} 
Например, одним из интересных выводов относительно «модели мира» в поэме А.Е. Кулаковского считаем следующее заключение современных исследователей: «Глобальные проблемы цивилизации, поставленные в поэме, позволяют говорить о том, что по глубине философских воззрений и умозаключений якутский поэт близок к русским космистам, идеи которых получили широкое распространение в конце XIX - начале XX вв.». Антропокосмизм Кулаковского утверждает «необходимость постоянного ощущения человеком своей органической, неразрывной и, самое главное, действенной связи с природой, $\mathrm{c}$ Космосом». В этом ракурсе полифункциональность ключевого образа поэмы также имеет определяющее значение: шаман с его «всевидящей» и «всеведающей» мифологической традицией выступает и «качестве философа» (Г.П. Башарин). «Вместе с тем образ шамана, несомненно несет в себе собственно-авторское, индивидуальное начало. ... На это указывает введенный автором образ Орла, ассоциирующийся с псевдонимом поэта ${ }^{27}$.

Сложный многоплановый сюжет, своеобразный историзм, художественная идея борьбы за благополучие своего народа и, наконец, непосредственное «присутствие» слушателей - все эти особенности жанровой природы поэмы Кулаковского позволяют увидеть ее художественный аналог в эпических произведениях якутского фольклора. И.В. Пухов при определении жанровой специфики олонхо подчеркивает особенности его сюжета и композиции, языка и стиля повествования, объема произведений, историзм и героический характер содержания ${ }^{28}$. В данном случае жанр эпических произведений фольклора не становится внешним шаблоном. Наоборот, поэтика «Сна шамана» послужила художественным толчком и основой проявления индивидуального, национального и исторического начал зарождающейся якутской художественной литературы. В самом названии автор сконцентрировал своеобразие произведения: в «сновидении», уточненном образом шамана, отражена «кодовая установка» жанровой особенности произведения, которое стало классическим произведением якутской литературы, ибо каждое поколение читателей раскрывает ее по-новому, находит в ней то самое существенное, что непременно перекликается с наболевшими проблемами данного времени.

Другая поэма А.Е. Кулаковского «Наступление лета» написана по мотивам народных песен о временах года. Песни о временах года,

27 Романова Л.Н., Дьячковская М.Н. «Сновидение шамана» Кулаковского и проблемы выживания цивилизации // Кулаковский и время. - М., 2003. - С.197-199.

${ }^{28}$ Пухов И.В. От фольклора к литературе. - Якутск, 1980. - С. 24-33. 
прославляющие родную природу, «с особой силой зазвучали в дни народных демонстраций в годы революции и гражданской войны». Причем самыми популярными стали песни о наступлении лета, «всегда жизнерадостные, носящие характер приветствия оживающей природе ${ }^{29}$. Поэма Кулаковского традиционно воспринималась как прославление начала новой жизни народа. Однако публицистический пафос не равняется главной идее произведения. Поэт и на этот раз расширил и уточнил обобщающие возможности народных песен, соединив в композиционное целое шесть частей, которые посвящены явлениям природы, соответствующим определенным отрезкам времени от самого начала весны до полного утверждения лета. Он воссоздает время в движении: однопланово развивающийся сюжет поэмы заключен в завязку, символически перекликающуюся с концовкой поэмы «Дары реки», и развязку-апофеоз как церемониальное воспевание наступления летнего солнцеворота - нового года по якутскому народному календарю - и как приветствие радости вообще.

В этом отношении композиция поэмы перекликается с основными признаками обрядовых песен, посвященных национальному празднику ысыах, в чем можно убедиться, обратившись к монографии С.Д. Мухоплевой: «Главным организующим звеном этого повествовательного компонента песни (ритуальной «Песни про ысыах» - П.М.) является прием причинно-следственного сцепления образов. Наступление нового года - причина наступления теплых дней, наступление жары - причина расцвета деревьев и произрастания трав; уход старого года - причина таяния снегов, ледохода, ледоход - причина произрастания трав. Таким образом, первый образ текста является причиной появления второго образа, а второй, в свою очередь, - причина третьего и т.д.» ${ }^{30}$.

К этой схеме приложим композиционную структуру поэмы «Наступление лета», которая четко отражена в названиях глав:

1)«Хаар хараарыыта, үрэх эстиитэ» («Таяние снегов, ледоход»); 2) «Үөн-көйүүр, көтөр-сүүрэр» («Насекомые, птицы, животные»); 3) «Этин, ардах» («Гром, дождь»), 4) «Сир көБөрүүтэ, от үүнүүтэ» («Земля зеленеет, трава растет»); 5) «Киһи-сүөһү кэскилэ» («Счастливая участь людей и скота»; 6) «Ыhыах» («Ысыах»). Как видим, причинно-следственное сцепление образов (глав) налицо. Данная композиционная форма естественно и просто прослеживается и в текстовой части каждой главы. И в этом случае автор, опираясь на фольклорную форму, раскрывает поэтическую идею о жизнеутверждающих началах природы в духе народного мировосприятия, на уровне

\footnotetext{
${ }^{29}$ Пухов И.В. Указ. работа. - С. 96-102.

${ }^{30}$ Мухоплева С.Д. Якутские народные обрядовые песни. Система жанров. - Новосибирск, 1993. - С. 84.
} 
народной эстетики определенного исторического периода его развития, отражая реальное время через систему концептуальных образов.

Поэтический стиль и тематическая направленность произведений А.Е. Кулаковского неизменны: он естественно продолжает фольклорные художественные традиции, гармонически сочетая с ними индивидуальноавторские идеи, созвучные с его историческим временем. В этом плане можем обратить внимание и на взаимосвязь образных и тематических тенденций его отдельных произведений. Вспомним, как охотник заканчивает свое обращение к Байанаю (1900 г.) вещими словами, выражающими его надежду на удачу:

Төлкөлөөх түөнэ манан түөрэх, Тэхтиргэ тэптэрэр, Очурга обустарар буолаайақыный! Туску-уо!

Сравним это с завершением поэмы «Сон шамана» (1910 г.):

Төлкөлөөх түөнэ манан түөрэх, Очурга ођустарар, Тэхтиргэ тэптэрэр, Туннэстэ түһэр буолаайаный! Тускуо!

Определяющая судьбу, моя ворожба,

О преграды бедствий не расшибись,

О помехи зла не споткнись, О, только не опрокинься! Удачу дай!

Тускуо!

(Перевод С. Поделкова)

Автор выражает народную веру в благополучие как знамение жизни в любом ее проявлении. Эта гуманистическая идея по отношению к судьбе народа прослеживается и в последующих произведениях. Сравним заключительные строфы стихотворения «Армия снежно-ледяной страны» (1925 г.):

Күөнэхпит күөрэйдэ

Күөрэгэйбит ыллаата,

Күммүт тагыста.

и поэмы «Наступление лета» (1924 г.):

Көрдөөх-нардаах

Күөх унаар сайын ийэбит

Күөйэ көтөн кэлэн, Күөрэгэйбит ыллаата, Күөнэхпит тађыста, Күммүт буолла, 
Көрүөх-билэ дьонуом.

Весело обступило нас,

Всюду восторг - и оттого

Жаворонок наш запел,

Живо пошла наша рыба играть,

Наше солнце взошло,

Сородичи дорогие мои!

(Перевод С. Поделкова)

В этих произведениях неизменное утверждающее определение жизни является ключевым понятием в раскрытии идеи произведений по принципу взаимометафоризации природы и человека, что в целом «работает» на усиление концептуальной образности.

\section{Контрольные вопросы и задания:}

1. Каковы отличия композиционной основы представленных поэм А.Е. Кулаковского?

2. В каких параметрах поэтики образов, проблематики и композиционных особенностей проявляется родовой синкретизм поэмы «Дары реки»?

3. На какие стороны и ракурсы темы, идеи, проблематики поэмы «Сон шамана» основываются критические выпады и анализ произведения в литературоведческих исследованиях разных авторов?

4. Какие художественные приемы можно считать принципом композиции в поэме «Сон шамана»?

5. Каковы функции хронологической композиции в поэме «Наступление лета»?

6. Какие фольклорные мотивы и образы являются опорными точками композиции поэм? Обоснуйте свои выводы по каждой поэме по-отдельности, или представьте развернутый анализ одного произведения.

7. В чем состоит сущность эпической систематизации образов, как проявляются художественные функции символических образов в поэмах А.Е.Кулаковского?

\section{Упражнения и задания для СРС:}

1. Определите и обоснуйте анализом отрывков из текста своеобразие композиции поэмы «Дары реки» на уровне образной системы.

2. В поэме «Дары реки» найдите элементы сюжета. Сформулируйте краткую характеристику образов и определите их художественные функции в раскрытии идеи произведения.

3. Сравните «Дары реки» со стихотворением М.Ю.Лермонтова «Дары Терека» и определите сходства и различия в параметрах темы, образов и в композиционных приемах.

4. Обоснуйте композиционную разбивку поэмы «Сон шамана» В.Н.Протодьяконовым анализом проблематики произведения.

5. Обоснуйте определение: «Сон шамана - эпическая поэма». На основе характеристики опорных точек композиции поэмы опишите своеобразие композиционных приемов на макро- и микроуровне. 
6. Сравните композиционные изменения в поэме «Сон шамана» в редакциях 1946 и 1976 годов по отношению к каноническому (авторскому) тексту поэмы по изданию В.Н.Протодьяконова.

7. Сравните пять первых частей поэмы «Наступление лета»с народными песнями и обоснуйте художественное значение литературной обработки фольклорных мотивов и образов в поэме.

8. Дайте развернутую характеристику соотношения первых пяти частей и шестой части поэмы «Наступление лета» на уровне идейно-тематического анализа поэмы.

\section{Литература}

1. Бурцев А.А. Наследие А.Е.Кулаковского в контексте мировой литературы // Кулаковский А.Е. и время. - М.: «Арт-Флекс», 2003. - С. 407-444.

2. Есин А.Б. Принципы и приемы анализа литературного произведения. - М.: ФлинтаНаука, 2000.

3. Кайда Л.Г. Композиционный анализ художественного текста. - М.: Флинта, 2000.

4. Максимова П.В. Жанровая типология якутской поэзии.- Новосибирск: Наука, 2002.

5. Романова Л.Н., Дьячковская М.Н. «Сновидение шамана» А.Е.Кулаковского и проблемы выживания цивилизации. - Кулаковский А.Е. и время. - М.: «Арт-Флекс», 2003. C. $190-215$.

6. Покатилова Н.В. А.Е. Кулаковский - первопоэт якутской традиции (истоки, эволюция, поэтика литературного творчества) // Кулаковский А.Е. и время. - М.: «АртФлекс», 2003. - С. 125-189.

7. Протодьяконов В.Н. Өксөкүлээх Өлөксөй уонна «Ойуун түүлэ» поэма кэмкэрдии дьүүлүгэр. // Өксөкүлээх Өлөксөй. Ойуун түүлэ. - Якутск: «Бичик», 1994. - С. 4463.

8. Сидоров Е.С. «Сон шамана» - памятник общественной мысли в Якутии. Комментарии. // Кулаковский А.Е. Сон шамана. - Якутск: «Бичик», 1994. - С. 3-61, 95-123.

9. Эрчимэн. Ойуун түүлүн проблематиката // Эрчимэн. Өксөкүлээх өрүҮ тыыннаах. Якутск: «Бичик», 1995. - С. 123- 152.

\section{3. О поэтическом стиле А.Е.Кулаковского}

A.Е. Кулаковскому как основоположнику литературы принадлежит и создание четкого авторского стиля. Исходя из того, что художественная структура произведения является объединяющим понятием в триаде «композиция», «стиль», «образ автора», рассмотрим данный вопрос на более конкретном проявлении авторского стиля - на особенностях художественной структуры поэтических произведений А.Е. Кулаковского. При этом имеем в виду, что в композиции выражается идея целостности - «феномен, определяемый не только и не столько жанром произведения, сколько 
литературно-художественным методом изображения действительности» ${ }^{31}$. А также полностью соглашаемся с тем заключением, что «только в системе, только в композиционном единстве можно исследовать стиль писателя, в противном случае выводы могут быть субъективными и бездоказательными» (Л. Кайда). Интересен и вывод о том, что без «композиции» мы теряем «дискурсивную организацию целого как натурально-языкового высказывания», ибо композиция «составляет основу субъектной организации литературного произведения». 32

Если попытаться рассмотреть своеобразие стиля А.Е. Кулаковского с представленной точки зрения, то основным проявлением композиционного строя произведений классика якутской литературы выступает принцип диалогизации. Парное сопоставительное или противопоставительное начало частей (строф или его вариаций, образного ряда) является основным структурообразующим понятием в поэзии Кулаковского. Более того, диалогичность в его художественном наследии прослеживается не только на уровне категории формы. Система основных слагаемых формальной структуры, а также их смысловое образное соотношение и взаимообусловленность в конкретных произведениях воплощаются в целостное художественное освоение мира именно по логическим принципам диалогов. Данную стилевую характеристику можно подтвердить примерами различного характера.

Во-первых, форма диалогов в крупных поэтических произведениях («Дары реки», «Спор между разумом и сердцем», «Обездоленный еще до рождения») создает художественную модель единства и противостояния двух идей. Именно в этой модели сохраняется своеобразие фольклорной поэтики при естественном расширении его художественных функций.

Во-вторых, мотив диалога «автор и читатель» или «персонаж и читатель» четко прослеживается в таких произведениях, как «Портреты якутских женщин», «Скупой богач», «Сон шамана», «Песня пьяного буржуя», «Песня столетней старухи» и др., где текст воспринимается непосредственным обращением автора или героя к слушателю. В этих произведениях эксплицитному высказыванию равняются образные портреты или своеобразные частные хроники, имеющие начало и завершение.

В-третьих, в художественном наследии классика однозначно четко прослеживаются принципы диалогического сопоставления частей крупных поэтических произведений. В поэме «Сон шамана» композиционная

31 Виноградов В. Стилистика. Теория поэтической речи. Поэтика. - М., 1963. - С.75; Кайда Л. Композиционный анализ художественного текста. - М., 2000. - С.32.

32 Тюпа В. Аналитика художественного. - М., 2001. - С. 54. 
двуплановость отражается в размышлениях о мировых проблемах цивилизации и о социально-политических аспектах жизни в России. По-своему диалогичен (двойствен) сам образ актанта, который выступает то как пророк, несущий народные традиции, то как реальный человек, размышляющий о своем времени. Шаман Кулаковского в обращениях к «своим слушателям» реализует и третий вид диалога, а именно, диалог «персонаж и читатель».

В поэме «Наступление лета» авторский дискурс реализуется в двух ракурсах. Автор представляет естественное развитие жизни в природе (первые пять частей о пробуждении растительного и животного мира) и сопоставляет ему описание встречи нового времени года в обществе людей (заключительная шестая часть - «Ысыах»). Поэмная идея раскрывается в данном случае в том, что природное начало выступает фоном и истоком в философском и логическом планах в развитии жизни общества. Именно в этой «последовательности» находится ментальная сущность якутского верования.

В-четвертых, парное смысловое и образное сочетание строф как основа повторяемости ритмических стиховых единиц наблюдается во многих произведениях поэта. Более того, это явление можно равнять организующему принципу структуры в поэтическом стиле А.Е. Кулаковского. Диалогическая основа повторов подчеркивается антитезой смысловых единиц. Например, в «Клятве Демона» противопоставления в оригинале усиливаются изменением строфики, где равная ритмическая структура частей и повтор ключевого слова отдельной строкой усиливают трагический пафос монолога:

Андақайабын

Аан дайды айыллыбыт чааһынан, КэнэБэс кини кэмэ-кэрдиитэ ситэринэн;

АндаБайабын

Аньыы алдьархайдаах саатынан.

Сытыйбат кырдьык кыайыытынан;

Андақайабын

Кыаттарар кырыыстаах кыһыытынан,

Кыайар кылгас ымсыытынан;

Андақайабын

Эйиигин кытары көрсөрүм үөрүүтүнэн,

АдаБыйан турар арахсыым абатынан.

(«Абааһы андақара»)

Клянусь

Всего мира создания часом,

Исполнением срока его в будущем;

Клянусь 
Страшным грешным позором.

Вечностью негниющей правды;

Клянусь

Предначертанной обидой поражения,

Завистью в миг победы;

Клянусь

Радостью встречи с тобой,

Горестью верной разлуки.

(дословный перевод наш. - П.М.)

В другом примере («Скороговорка») находим противопоставления формульной этимологии, где парные словосочетания используются в целях расширения обобщающего значения образов («Тойон-торьон, үтүө-мөкү, аһыы-ньулуун ... итии-тымныы, илин-арқаа»). Но в этом произведении в целом диалогично философское противопоставление смысла жизни. Реальные проблемы настоящего поэт раскрывает через оптимистическое духовное начало как проявление народного восприятия обстоятельств в их временной сущности в духе классических изречений типа «Sunt certi denigue fines» или «Suum cuigue rei tempus est». («Всему конец, есть границы»- выражение Горация. «Всему есть свое время»).

Поэтика парного противопоставления раскрывается и на примерах сокращений в текстах А.Е. Кулаковского в изданиях советского периода. Обратимся к стихотворениям «Красивая девушка» и «Узнавший-увидевший».

В тексте изданий 1946 и 1957 гг. из стихотворения «Красивая девушка» исключено одно слово «нуучча» (195 строка)- «бэрдимсик мэтириэтчит нуучча», что, на первый взгляд, не меняет содержания. В остальных выражениях трехчастного повтора («великий олонхосут», «самодовольный портретист», «известный знаток всего - образованный человек») нет прямого названия национальной принадлежности, скажем, персонажей. Пропущенное слово включено в издание 1978 г. Следует особо отметить, что именно в этом случае описание поэта получает логическое завершение. Ибо на самом деле речь идет о самодовольном портретисте (о русском художнике); о великом олонхосуте-певце (о красноречивом якуте) и об общеизвестном образованном человеке (т.е. и о русском, и о якуте - «үс дойду үрдүнэн өйдөөБүнэн аатырбыт»).

Из текста стихотворения «Билбит-көрбүт» во всех трех основных изданиях исключены строки 91-92, что на первый взгляд не вносит существенного изменения в содержание. Однако отсутствие дистишия нарушает стройную логическую цепь авторских «рассуждений». Композиция произведения, представляющего образные определения крайних явлений жизни 
и нравов в их парных сопоставлениях, теряет одну существенную образную и смысловую деталь. В завершающей стихотворение динамической системе из восьми строк, где сопоставления 89-90 и 91-92 стихов представляют противопоставление последующей паре двустиший, оставлена в изданиях усеченная первая часть (отметим курсивом пропущенные строки):

Уолан киһи курдук

Омуннаауы булбаппын,

Итирик нуучча курдук

ИмэннээБи билбэппин
Не знаю пылкого

Как неопытный молодец,

Не ведаю страстного

Как русский после выпивки

(дословный перевод наш - П.М.)

Образное единство четырех строк автор подчеркивает знаком препинания [,] между двустишиями. Далее идет такая же пара нравственных проявлений противоположного порядка, подтверждая обобщенную образную картину реальной жизни в четком ритме стихов и академической строгости смысловых сопоставлений:

Күтүөт ођо курдук

Көссүөнү көрбөппүн,

Кийиит ођо курдук

Килбиги билбэппин.
Не знаю смирного,

Как юноша-зять,

Не ведаю стеснительную,

Как девушка-невеста.

(дословный перевод наш - П.М.)

Наряду с антиномиями художественных деталей или элементов детализации А.Е. Кулаковский использует внутренний психологический параллелизм, что наблюдаем в описаниях портретного характера. Данный прием служит смысловой основой эпической фабулы. К примеру, в таких произведениях, как «Кэччэгэй баай», «Итирик бурсуй ырыата», «Эр аһыыта», «Кырасыабай кыыс» авторская идея развивается по логике представления героя от его внешнего вида, описания обстановки, социального фона до конкретизации его внутреннего облика или от детальной характеристики обстоятельств до заключительной оценки значения факта жизни. В этих произведениях диалогичны внешнее и внутреннее начала в поэтических образах, описание которых строится в виде цепи деталей, приобретающих чем дальше, тем большее значение для раскрытия идеи. В них весь текст последовательно и четко приводит к авторскому выводу, подчеркивая его значимость логической убедительностью «перечисленных» деталей как социального и духовного смысла частей целого.

В-пятых, диалогическая связь наблюдается и в выборе той или иной темы или в обращении к тем или иным образам. Например, социально-философская идея цикла «Портреты якутских женщин» дополняется и углубляется «в диалоге» со стихотворением «Красивая девушка». Также логическую пару 
составляют «Деревенская женщина» и «Городские девушки»; «Плач по умершему мужу» и «Песня пьяного буржуя». Поэмы «Дары реки» и «Наступление лета» перекликаются через образ реки Лена. «Обездоленный еще до рождения» и «Певец» представляют рассуждения о разных судьбах через поэтическое раскрытие темы о предназначении человека. «Заклинание байаная» и «Сон шамана», «Благопожелание среднему поколению» и «Благопожелание по-старинному» диалогичны по раскрываемой социально-философской идее.

Таким образом, можно заключить, что 1900-1925 годами датируются произведения основоположника якутской литературы для доказательства целостности его литературного наследия. Ровно четверть века - это тот реальный отрезок времени, который определил А.Е. Кулаковского как явление историческое, эпохальное, чья поэзия своей содержательной глубиной, высотой художественной культуры, четкостью авторского стиля стала вершиной якутской классической литературы. Именно его поэмы выступают «жанромкладезем» (Л.С. Мелихова) для дальнейшего развития национальной литературы. И в этом плане родовой синкретизм крупных произведений А.Е. Кулаковского объединяет в себе жанровые и тематические возможности зарождающейся литературы как вида словесного творчества. Фольклорная форма - поэтические тропы, жанровые аналогии - выступает «имманентной логикой творчества», которая сочетается с естественным «приемом обработки определенного содержания... с помощью определенного материала» (M.M. Бахтин). На данной основе поэзия Кулаковского в отличие от произведений предшествовавших ему авторов (А.Я. Уваровского, М.Н. Андросовой, старшего брата И.Е. Кулаковского и др.) положила блестящее начало формированию якутской художественной литературы: наполненность авторскими общественно-политическими идеями, социально-философскими мыслями в его литературном наследии стала непревзойденным новаторством Кулаковского как писателя. Он поднял значение художественного творчества в духовной жизни народа, чему способствовали и реальные события первых десятилетий XX в., сопровождавшиеся коренными изменениями привычных устоев общественной жизни. А.Е. Кулаковский тем самым выступил в равной степени писателем и мыслителем исторического масштаба.

Фольклор как жанровый спектр отражается в литературном наследии Кулаковского в органическом единстве традиционно-национального художественного опыта с индивидуальным авторским стилем. Но если целый ряд его стихотворений более четко представляет генетическое родство с песенной формой устного народного творчества, то поэмы, а также философская поэзия - средние величины в творчестве классика - своим 
социальным, общественно-политическим звучанием подтверждают зарождение якутской художественной литературы с ее самобытными родовыми, жанровыми и стилевыми проявлениями. Родовой синкретизм первых крупных поэтических произведений и образная определенность одногеройных поэм, раскрывающих концептуальные идеи, заключают в себе естественный сплав устойчивых традиций художественной словесности (язык, поэтические тропы, стиховая организация) и оригинальных жанровых поисков авторов (особенности фабулы, композиция, система образов) в период становления якутской художественной литературы. Эпическая поэзия А.Е. Кулаковского выражает в целом глубинную философскую мысль об особенностях этических проблем нации и исторической судьбы народа.

Классическая закономерность установления литературных норм в творческом наследии Кулаковского неоспоримо доказывается приоритетом авторского начала, в котором проявляется подчеркнутая М.М. Бахтиным основная идея проблемы автора - умение художника «быть внежизненно активным», т.е. быть выше, мудрее «жизни (практической, социальной, политической, нравственной, религиозной)» и найти существенный подход к форме и материалу, чтобы «преходящее мира обретало ценностный событийный вес, получало значимость и устойчивую определенность» ${ }^{33}$.

Поэтическое наследие А.Е. Кулаковского в целом тоже является диалогом поколений, или диалогом Поэта со своим народом. Известно, что писателиклассики - «вечные спутники человечества» (Д. Мережковский). В свете этого изречения, диалог как авторский дискурс более емко и верно раскрывает значение поэзии А.Е. Кулаковского. Равняет его творчество непреходящему духовному богатству народа, наследию, положившему начало якутской художественной литературе.

\section{Контрольные вопросы и задания}

1. Какие художественные приемы организации текста выступают характерными деталями в поэзии А.Е. Кулаковского?

2. Какие элементы композиции фольклорных произведений получают литературное развитие в поэзии А.Е. Кулаковского?

3. Можно ли связывать со- и противопоставления частей текста с выражением авторской идеи в произведениях «Абааһы андақара» и «Узнавший-увидевший»?

4. В каких ракурсах темы, идеи и проблематики наблюдается диалектическая связь между отдельными произведениями основоположника якутской литературы? Назовите такие пары или систему произведений и дайте краткое обоснование своего вывода.

\footnotetext{
${ }^{33}$ Бахтин М.М. Эстетика словесного творчества. - М., 1986. - С. 162-167.
} 
5. Какое место и значение имеет исторический контекст в крупных произведениях A.Е. Кулаковского?

6. Какие элементы композиции и образной системы можно отнести к характерным особенностям стиля писателя?

7. В чем особенно ярко проявляется влияние художественных форм русской классической литературы на творчество А.Е. Кулаковского?

\section{Упражнения и задания для СРС}

1. Примерами из текстов А.Е. Кулаковского обоснуйте принципы диалогического сои противопоставления как художественный прием создания композиции поэтического произведения.

2. Дайте систематизированную детальную характеристику актанта по поэме «Сон шамана».

3. Сделайте подробный текстологический анализ стихотворений «Узнавшийувидевший» и «Красивая девушка» с развернутым обоснованием принципов редакций в изданиях 1946 и 1957 годов.

4. Сделайте сопоставительный композиционный анализ поэмы «Сон шамана» по редакциям 1946 и 1978 годов с авторским текстом.

5. На основе особенностей организации текста сделайте обоснованную характеристику места и роли автора в одном из произведений А.Е. Кулаковского (по выбору).

6. Сделайте композиционный анализ поэмы «Дары реки».

7. Определите особенности композиции поэмы «Наступление лета»

\section{Литература}

1. Бахтин М.М. Эстетика словесного творчества. - М.: Искусство, 1979.

2. Васильев Г.М. Якутское стихосложение. - Якутск: Якутское книж. изд., 1965.

3. Дьячковская М.Н. Аллитерация и рифма в якутской поэзии. Проблемы эволюции и классификации. - Новосибирск: Наука, 1998.

4. Есин А.Б. Принципы и приемы анализа литературного произведения. - М.: ФлинтаНаука, 2000.

5. Пухов И.В. От фольклора к литературе. - Якутск: Якутское кн.изд-во, 1980.

6. Романова Л.Н. А.Е.Кулаковский и его современники. - Новосибирск: Наука, 2002.

7. Слепцов П.А. Якутский литературный язык. Истоки. Становление норм. Новосибирск: Наука, 1986.

8. Тобуроков Н.Н. Якутский стих. - Якутск: Якутское кн. изд-во, 1985. 


\section{ІІ глава. ПОЭМЫ А.И. СОФРОНОВА}

\section{1. Авторский дискурс и композиционные мотивы}

Эпическая поэзия А.Е. Кулаковского не могла не влиять на творчество А.И. Софронова (1886-1935). Однако верно и то, что у А.И. Софронова в большинстве случаев реминисценции являются невольными, что можно объяснить естественным влиянием народной поэтической культуры на творчество писателя. Прав академик П.А. Слепцов, увидевший в этом явлении преемственность в развитии норм литературного языка в освоении фольклорных ресурсов ${ }^{34}$. Кроме генетической близости языковых особенностей, в живой преемственности традиции А.Е. Кулаковского типологическое сходство наблюдается в жанровом аспекте, что находим на уровне проблематики крупных произведений классиков. Однако в этом плане в художественном наследии А.И. Софронова отмечаем особенность авторского дискурса, существенно отличающегося углубленным психологизмом восприятия реального мира, реальной общественной среды. Поэмные образы А.И. Софронова как целостное представление конкретного места и времени наделены особой метахудожественностью.

Резонно сослаться на определение этого термина: «Художественность категория, транспонированная на специфику и ценностное качество искусства. Метахудожественность - это уже то, что определяет человеческое сознание. ... Метахудожественность, в отличие от художественности не выделяет подлинное искусство от неподлинного, а подводит нас к его онтологическому бытийственному смыслу». ${ }^{35}$ Из этого определения следует, что понятие «метахудожественность литературного образа» представляет органическое единство динамичного художественного слова с авторским началом на уровне образов-мотивов и топосов. Для читателя это целостное понятие тесно переплетается с восприятием исторического времени как времени автора. Таким образом, данный стилевой ракурс дискурсивен.

На следующее десятилетие после создания программного произведения основоположника якутской литературы А.Е. Кулаковского («Сон шамана»), А.И. Софронов в поэме «Разговор священных гор» ставит эпическую проблему судьбы нации. А другое его произведение, стихотворение «Судьба священных гор», датированное тем же 1921 г., воспринимается прологом к названной

${ }^{34}$ Слепцов П.А. Якутский литературный язык. Истоки. Становление норм. - Новосибирск: Наука, 1986. C. 94.

${ }^{35}$ Гей Н.К. Метахудожественность литературы // Теория литературы. - М.: ИМЛИ РАН, 2005. - С. 97-98. 
поэме. Оба произведения, воспринятые критикой 1920-х годов как националистические, стали достоянием широкого круга читателей в 1990-е годы.

А.И. Софронов в стихотворении и в поэме обращается к образности эпических сказаний: тропы, строфика восходят к описаниям олонхо, а реально историческая тематика перекликается с обрядовыми представлениями о судьбе, мире природы, что также придает иносказательному содержанию произведений эпическую монументальность. Поэтому нелегкие думы автора в годы гражданской войны в Якутии обретают смысловую весомость в духе «Сна шамана». Но аналогичная проблематика раскрывается в поэме А.И.Софронова в ином композиционном решении, а именно, в форме диалога двух персонажей, не исключающего действенного «присутствия» авторского «я». Монологи Священных гор раскрывают суть гражданской войны, когда друг на друга идут с оружием братья по крови, и в этой невиданной доселе горести Гора-Хотун (Госпожа, охранительница Прекрасной Туймаады) упрекает своего старшего брата Гору-Тойон (Господина, Защитника долины предков), открывшего дорогу пришельцам с южных сторон. Вот здесь пафос поэмы А.И. Софронова перекликается с идеей обращения шамана А.Е. Кулаковского: гражданская война воспроизводится неминуемым историческим продолжением революционных событий в России. Но в раскрытии основной темы произведения А.И. Софронова решающую роль играют слова автора, «уточняющего» смысловую динамику диалога предсказаниями провидцев сказителей древней мудрости. Поэт излагает в двух произведениях их вещие легенды о Священных горах, предназначенных охранять добрых духов земли. Таким образом, А.И. Софронов в художественных образах Гор воплощает метафорический образ Земли предков, что выступает главным отличительным аспектом поэмы по отношению к образной идее «Сна шамана». Ибо образ Родины, углубленный иносказательными монологами о судьбе народа, подчеркивает доминанту лирического начала в поэме А.И. Софронова: в философском обобщении идеи произведения авторская линия является ключевым компонентом жанрового своеобразия. Отсюда сходная проблема в поэме «Сон шамана» и в дилогии А.И. Софронова в силу особенностей авторских стилей раскрывается в различных жанровых формах: эпической и лирической, что четко проявляется в финале. Если поэма А.Е. Кулаковского заканчивается предсказанием-алгысом, обращенным к народу от имени шамана, как того «требует» композиция, фабула произведения, то «Разговор Священных гор» завершается самим автором. В открытом финале поэт делает вывод об особенностях реального времени - о начале 1920-х годов. И в самом тексте 
находим конкретизацию фактов жизни именно в указанном времени. Подтвердим это словами Тойон Хайа. Он отвечает на упреки Сестры следующим образом:

Почтенная Сестра!

Отец мой Ат Дабаан ...

Лицо свое повернул в другую сторону.

Чтобы обосновать другие роды,

Остановить (у себя) иных людей,

Присоединился со смелыми,

Ведет знакомство с лучшими.

Меня же

Чтобы не двигался с места, цепью заковал;

Запретив слово сказать,

Повелел ничего не видеть

Два года тому назад. ${ }^{36}$

(дословный перевод наш. - П.М., курсив мой. - П.М.)

Так автор указывает на 1919 год. Отражение реального времени в раздумьях лирического героя - это особая авторская позиция в стихотворениях и поэмах А.И. Софронова в целом. Объяснение данного явления лежит в условиях и обстоятельствах жизни поэта, творчество которого время обновляет, представляя новые пласты его произведений.

В этом плане одним из ярких примеров выступает поэма «Письмо отцу», написанная во время ссылки и опубликованная впервые в сборнике избранных произведений в 1965 г. (С. 334-352). Поэма состоит из вступления и 18 глав, где рассказ-исповедь лирического героя отражает непростое содержание социально-исторических конфликтов личности и общества. Можно сказать, что это - главная тема всего творчества А.И. Софронова. Но здесь он раскрывает ее в новом ракурсе, осуществляя в «письме» естественное сочетание народности с социально-нравственными проблемами гражданского содержания. Так историческое время и реальный человек приобретают художественную силу и философское обобщение в доверительном характере изложения лирического сюжета. А строгая композиционная система поэмы отражается в названиях глав, сама последовательность которых основана на концептуальной идее.

Первые четыре главы: «Эн», «Мин», «Иһит», «Өйдөө» («Ты», «Я», «Слушай», «Пойми»). Эти названия могут быть сформулированы в виде обращения: «Эн миигин иһит, өйдөө» («Ты меня слушай, пойми»).

\footnotetext{
${ }^{36}$ Софронов А.И. Ырыа быстыыта хоһоон. - Якутск, 1996. - С. 48-49.
} 
V - IX главы: «Билигин», «Биллим», «Куттанным», «Дьулайдым», «АраБыстым» («В настоящее время», «Узнал», «Испугался», «Мне стало страшно», «Отстранился»).

X - XIII главы: «Билинэбин», «Мин», «Альас», «Ыллаабытым-туойбутум» («Признаюсь», «Я», «По ошибке», «Пел-воспевал»). В Х главе напряжение мысли лирического героя достигает кульминационного момента и дальше постепенно переходит в размышления о настоящем, что отражается в названиях последующих глав.

XIV - XV главы: «Ол эрээри», «Уларыйдым» («Но», «Изменился»).

XVI - XVIII главы: «Көрдөһөбүн», «Билбитим», «Бырастыы» («Прошу», «Узнал», «Прощай»).

Особую смысловую значимость названий глав подтверждают повторяющиеся заглавия «Мин» («Я») - II, XI главы; «Биллим», «Билбитим» («Узнал») - VI, XVII главы, входящие в состав разных «предложений». В целом названия группируются в четырех синтаксических единицах, где представлены глаголы - однородные сказуемые; наречия - обстоятельства; союз противопоставление; личные местоимения - обращение, подлежащие.

Таким образом, на первый взгляд, полная грусти и печали интимная лирика под пером А.И. Софронова превращается в обстоятельную эпическую характеристику судьбы поколения первой трети XX века. В примечаниях к поэме автор указал, что сначала писались отдельные части как самостоятельные стихотворения под общим названием «Моя лебединая песня». Поэт перевел это образное выражение на якутский язык в виде оригинального метафорического изречения «Ырыа быстыыта хоһоон». Но перевод его самого не удовлетворил, и вдруг пришло название «Письмо отцу». В это время - шел второй год ссылки в Архангельской области - в Таттинском улусе жил единственный родной человек поэта - его престарелый отец. Отсюда исповедальный сюжет, обращенный к отцу, запоздалое признание неисполненного сыновнего долга перед ним придают поэме сугубо личностный характер. И сам автор отмечал, что стихи писались для себя, чтобы развеять печальные думы о прошлом в форме народной песни «дьиэрэтии». Однако в тех же примечаниях, определяя особенности и значение этого произведения, он третьим пунктом выразил следующее предположение: «... скажу к примеру - если я известен народу саха как писатель, то прожитая мною жизнь, возможно, будет вызывать впоследствии какой-нибудь интерес...» (перевод наш - П.М.) ${ }^{37}$.

Так для современного читателя в поэме А.И. Софронова посвящение сына отцу перерастает в обращение поэта к народу. Примечательно и то, что для

\footnotetext{
${ }^{37}$ Софронов А.И. Талыллыбыт айымньылар. Т.2. - Якутск, 1965 - С. 311.
} 
полного раскрытия темы о разочаровании и неверии личности, о мучительных думах и не умирающей надежде поэта он находит подходящий жанровый образ - «Письмо отцу». Именно это название произведения можно равнять обобщающему авторскому дискурсу, где сила субъективно-психологической трактовки времени обретает философскую глубину. Поистине можно сопоставить жанровые поиски А.И. Софронова с классическим жанровым решением А.Е. Кулаковского в его поэме-концепции «Сон шамана», где формулировка названия равняется жанровому коду произведения.

Ко времени ссылки в Архангельской и Иркутской областях относится создание самого крупного (около 1700 строк) поэтического произведения А.И. Софронова «Ини-бии» («Братья», 1929), через повествовательный сюжет которого проходит образ большого писателя, вынужденного вдалеке от родины лишь воспоминаниями о прошлом скрашивать свою жизнь. Но воспоминания необычные: А.И. Софронов в этой оригинальной поэтической притче «оживляет» героев своих крупных драматических произведений. В фаталистической концепции «игры жизни» в «рассказе в стихах» (именно так определяет жанр этого произведения сам автор - «Дьүөрэ тылынан кэпсээн») героями выступают три брата из некогда состоятельной благополучной семьи. Оставшись наследниками отца, два старших брата быстро пускают на ветер деньги и богатства: Спиридон - в бесконечных праздниках с «друзьями», Гаврил - игрой в карты. Образованность, интеллигентность быстро забываются, и жалко кончается их жизненный путь. А младший, на первый взгляд, более разумный, продолжая дело отца, трудом и потом достигает желаемого уровня. Но новая власть, лишив его всех прав, тоже по-своему, отправляет по миру. Пессимистический сюжет «грустного рассказа» («кэрэгэй кэпсээним») включает в свое русло и тему одиночества. Здесь одинок каждый: и персонажи, и поэт. Так, наряду с главными героями притчи, раскрывается образ писателя через выражение любви к родному слову. Язык, стиховая организация произведения А.И. Софронова подкупают поэтической красотой, выводы о жизни и времени мастерским обобщением социально-философского характера. Поэт мудро «беседует» со своим читателем:

Настаиваете, чтоб я пел и пел,

Настойчиво просите, чтоб я писал и писал,

Заставляете без конца рассказывать.

О чем буду писать?

От прошлой жизни отошел,

С настоящей разошелся. 
И далее признается от всего сердца:

Что священники только безголосы,

Что купцы только толсты,

Что нахрапистые только (все) богачи,

Так односторонне писать

Мне весьма совестно,

Отчего-то сомневаюсь. ${ }^{38}$

(дословный перевод наш. - П.М.)

В этом спокойном рассуждении писатель оформил свое полемическое обращение к зарождающейся новой литературе.

Эпическая поэзия А.Е. Кулаковского представляет в целом выражение глубинной философской мысли об особенностях этических проблем нации и исторической судьбы народа. А в лирической поэзии А.И.Софронова истоком идеи выступает проблема нравственности в процессе коренного переустройства общественных отношений, что получило поэтическую реализацию в форме раскрытия душевного состояния лирического героя. Именно к жанру лирической поэзии он обращался в особо трудные периоды своей жизни. По содержанию двух последних изданий, из 340 опубликованных поэтических произведений А.И. Софронова к 1921-1929 гг. относится 272 произведения. А.И. Софронов также знал, что его поэзия адресована будущим поколениям. До середины 1930-х годов, при жизни автора, на страницах периодической печати республики увидело свет всего лишь менее двух десятков его стихотворений. А.И. Софронов был известен больше как драматург и общественный деятель. Это обстоятельство жизни, уместно полагать, сообщало его поэзии сугубо личностный характер, усиливало психологизм размышлений. Обширное поэтическое наследие А.И. Софронова в виде «Избранных произведений» впервые дошло до читателя в 1959 г. Этот сборник представил 96 самобытных произведений писателя. Существенно дополнили его содержание последующие (1965, 1976 гг.) издания: в читательский актив вошло около 200 стихотворений и поэм. А в 1996 г. вышла новая книга не изданных ранее, запрещенных произведений поэта - всего 180 названий, из них 166 стихотворений и поэм ${ }^{39}$. Авторские комментарии к стихотворениям и поэмам убеждают, что он дорожил ими, предполагал их значимость для оценки времени в целом и своей творческой судьбы, в частности. Все эти факты и обстоятельства придают поэзии А.И. Софронова особую психологическую глубину в раскрытии темы

\footnotetext{
${ }^{38}$ Софронов А.И. Талыллыбыт айымньылар. Т.2. - Якутск, 1965. - С. 364-365.

${ }^{39}$ Софронов А.И. Ырыа быстыыты хоһоон. - Якутск: Сахаполиграфиздат, 1996. - С. 398.
} 
любви к Родине, что равняется философскому осмыслению исторического времени через образное представление лирических переживаний.

\section{Контрольные вопросы и задания}

1. Какова история создания и история публикации представленных поэм А.И.Софронова?

2. Как соотносятся между собой тема, идея и проблематика в поэмах А.И.Софронова? Подготовьте ответы в виде сопоставительного анализа с произведениями А.Е.Кулаковского.

3. Какие основные функции диалога можно выделить в композиционном строе поэмы «Разговор Священных гор»?

4. Сформулируйте определение понятия «авторский дискурс» на примере поэмы «Письмо отцу», на этой основе определите его своеобразие в поэме «Разговор Священных гор».

5. Какова роль фольклорных средств выразительности в представленных поэмах А.И.Софронова? Определите ее на уровне жанровых особенностей, поэтического языка, тропов и особенностей стиха.

6. Определите тему, идею и проблематику в рассказе в стихах «Братья» на основе анализа лирических отступлений. С каким из драматических произведений автора можно сопоставить его по теме и проблематике?

\section{Упражнения и задания для СРС}

1. Подберите из лирики А.И.Софронова произведения, близкие по художественной идее и образам к поэме «Разговор Священных гор». Обоснуйте их близость на уровне анализа образной системы, мотивов и топосов. Сопоставьте время создания произведений и определите характер психологизма лирики поэта.

2. Определите сходства и различия произведений А.И.Софронова «Судьба Священных гор» и «Разговор Священных гор» с поэмой А.Е.Кулаковского «Сон шамана» в проблематике, образе и месте автора, в композиционных приемах.

3. Определите опорные точки композиции поэмы «Письмо отцу» и дайте характеристику основных композиционных приемов.

4. На основе анализа поэмы «Письмо отцу» определите значения понятий «историческое время» и «авторское время». Сделайте развернутое обоснование своих выводов об их «совпадении» и «несовпадении» в художественных произведениях.

5. Сделайте анализ хронотопа в рассказе в стихах «Братья», определите художественные приемы психологизма в раскрытии образов персонажей, роль и значение лирических отступлений в раскрытии темы и идеи произведения.

\section{Литература}

1. Билюкина А.А. Алампа... (Жизнь и творчество) - Якутск: ИГИ АН РС (Я), 2001.

2. Бурцев А.А. Введение в историю якутской литературы. - Якутск: Сахаполиграфиздат, 2004.

3. Гей Н.К. Метахудожественность литературы. // Теория Литературы. Т. 1. Литература. - М.: ИМЛИ РАН, 2005. - С. 96-141.

4. Семенова В.Г. Анемподист Софронов поэзията. - Якутск: Изд-во ЯГУ, 2002. 
5. Тобуроков Н.Н., Семенова В.Г. Алампа. - Якутск: Бичик, 2005.

\section{2. Композиционные особенности лирических поэм А.И. Софронова. «Разговор священных гор», «Письмо отцу», «Братья»}

Определение места и роли поэтического нарратива в лирических поэмах имеет особое значение в композиционном анализе. Относительно специфики объектной организации лирического дискурса В. Тюпа делает следующее интересное заключение: «... Непрерывности или циклической повторяемости (прецендентности) жизненного процесса путем его эстетического сгущения придается облик беспрецедентного события. Часто лирический сюжет сводится к одному единственному пространственно-временному и деятельностному контексту (эпизоду)» ${ }^{40}$.

Таким образом, тема в лирических поэмах раскрывается через авторское воспроизведение объективного образа-события. В них «система кадров внутреннего зрения и система голосов» (фокализация и глоссализация) имеют особое значение в виде главных составляющих «экзистенционального сверхсобытия (эйдос)». Авторский дискурс в лирических поэмах - это пространственно-временное действие, осуществляемое в форме художественной систематизации и эстетического оформления эмоциональноволевой установки автора. При этом сюжетная динамика лирических поэм нередко приводит к раздвоению субъективного мира, представленный в поэме образ раскрывается в кадрах внутреннего зрения, систематизирующихся в виде монологов, адресованных объективной действительности или диалогов, принадлежащих на самом деле одному субъекту. Данная особенность может быть названа художественным воспроизведением эйдоса.

В представленных выше лирических поэмах А.И. Софронова наблюдаются два типа композиционного решения в раскрытии темы: монологи в форме обращений к равноценному образу-идее или метафорическому образусимволу и в определенной степени, объективированное создание поэтических образов, представляющих авторское видение мира. То есть поэмные образы представляют многоуровневое раскрытие художественной идеи путем представления «экзистенционального сверхсобытия». Для поэм А.И. Софронова характерно создание ассоциативного образа изначально равного представлению времени, а понятие «экзистенционального сверхсобытия» равняется воспроизведению реальных моментов сложной судьбы поэта, пережившего

\footnotetext{
${ }^{40}$ Тюпа В. Аналитика художественного. - М., 2001. - С. 104.
} 
«эпоху перемен» (Конфуций). Отсюда исходит неординарная значимость образов и идеи его произведений, особенно его поэм.

Главный композиционный прием в «Разговоре Священных гор» диалоги однопорядковых образов, которые усиливают эмоциональный мир поэмы. Глоссализацию текста на уровне авторского начала находим в диалектике архаических и современных для поэта метафор, представляющих смысл непреходящих ценностей во временном контексте. Архаическое в системе метафор выступает носителем возвышенного начала, что специально подчеркивается автором в предшествующем поэме стихотворении «Судьба священных гор». Согласно старинным преданиям, Горы предназначены быть хранителями жизни долины Туймаады. В стихотворении и в поэме образы диафорического ряда - Духи Земли предков, старцы-предсказатели, мотивы трехярусного мира - приближают лирический дискурс к мифологическому представлению судьбы и предназначения.

Функция авторского слова в самой поэме, имеющей подзаголовок «Омун» («Фантазия»), заключается в представлении главных «персонажей». В силу этого вступление воспринимается в композиционном плане зачином в значении эпизода ожидания. Северные горы поэт называет Госпожой, южные Господином, и они в обращениях друг к другу раскрывают главную идею произведения, а именно, размышления о судьбе народа, переживающего трагедию гражданской войны. Таким образом, систему кадров внутреннего зрения (фокализацию) составляют картины действительности, отражаемые в диалогах Священных гор. В первом обращении Хотун Хайа (Госпожи) к «Почтенному брату» и в его ответе подчеркивается драматизм времени. Во втором «слове» Хотун Хайа, упрекающей Брата в медлительности и требующей от него действенного беспокойства о людях, сюжетный мотив достигает кульминации. Ответ Тойона Хайа (Господина) равняется оправданию надежды Хотун Хайа и воспринимается заключением поэмы. Однако глоссализация на уровне текста дополняется словом поэта, заканчивающего художественную реальность произведения вторичным эпизодом ожидания:

\footnotetext{
Не заканчивая, завершаю, Не объясняя, откладываю, Не досказав, робко кончаю, Речь моя не развивается, Язык мой не раскрывается, Стихи мои иссякли, Друзья-читатели, По ошибке не осуждайте.
} 
Действительно настало, дети мои,

То время, особенность которого

В том, что об известном молчат,

Размышления свои прячут,

Об услышанном не говорят...

(дословный перевод наш. - П.М.)

Таким образом, композиция лирической поэмы А.И. Софронова на уровне объективного текста орнаментальная. Авторское начало обрамляет диалоги композиционным тождеством начала и конца, тем самым углубляет образную систему поэмы в качестве единого эстетического представления экзистенционального сверхсобытия. Внутри основного текста орнаментальная повторяемость наблюдается в диалогах. Первое и второе обращения Хотун Хайа и ответы Тойона Хайа, представляющие динамику авторской мысли, усилены аналогичными поэтическими фигурами, что уточняет циклический характер мотива иносказаний. Однако в их разговоре наблюдаем незаконченный образный цикл, который органически вписывается в метафорические контексты начала и конца поэмы.

В поэме «Письмо отцу» размышления о судьбе соответствуют «сюжетным мотивам», раскрывающим образ времени в виде систематизации периодов жизни лирического героя. Структурное своеобразие в данном случае отражено в названиях каждой части. Если лирические стихи часто остаются без названия, что в целом характерно и для творчества А.И. Софронова, то в «Письме отцу» названия частей как сегмент композиционного порядка подчеркивают устойчивые композиционные принципы произведения. Они на протяжении всего текста систематизируют и уточняют идейные мотивы каждой части и тематические границы поэмы в целом. Заглавия в лирической поэзии по-особому «манифестируют авторскую активность», что подчеркивается в анализе лирической композиции следующим образом: «Особо существенна роль заглавия в аспекте соотнесенности разворачиваемой перед нами системы факторов художественного впечатления с креативной версией данного текста. При наличии заглавия оно становится авторской «темой» сколь угодно протяженного высказывания, а весь последующий текст - его «ремой» ${ }^{41}$.

Композиция поэмы «Письмо отцу» строится на циклическом развитии идеи, раскрываемом относительно самостоятельными частями-картинами жизни лирического героя. Мотив циклизации при этом наблюдается на двух уровнях. Микроуровень фрагментов текста представляют группировки восемнадцати частей на пять типологических единиц. Начальная единица -

\footnotetext{
${ }^{41}$ Тюпа В. Указ. Работа. - С. 105.
} 
обращение к адресату (Отцу), что формируется в виде вполне законченного высказывания: «Ты меня слушай, пойми», подчеркнутого названиями четырех частей-фрагментов. Следующая ступень композиции определяется нами пятойдевятой главами поэмы, где раскрывается драматизм судьбы лирического героя, естественность намерений которого не соответствует требованиям новой власти. Эта начальная концепция выражается в открытом признании: «В настоящее время узнал, испугался, мне стало страшно, отстранился». Третья ступень циклической композиции (десятая-тринадцатая главы) представлена обращением к прошлому, что противопоставляется настоящим реалиям жизни поэта: «Признаюсь, я по ошибке пел-воспевал». Четвертую единицу в нашей группировке составляют четырнадцатая и пятнадцатая главы поэмы, возвращающие читателя к идее второй ступени. Они также сформулированы в названиях частей-фрагментов: «Но изменился». Заключают исповедь лирического героя шестнадцатая-восемнадцатая части, где раскрывается идея, равная приятию поэта судьбы такой, какой она сложилась: «Прошу, узнал, прощай».

Таким образом, главным мотивом, определяющим идею поэмы, выступает динамический образ времени, представленный в деталях-картинах жизни лирического героя. Оригинальность решения этого мотива заключается в том, что переживание направлено на выражении постепенного отдаления от общества. В этом плане циклическая композиция выступает более подходящим приемом создания образа времени, равной картине мира. Именно временной дискурс способствует психологическому углублению в размышлениях о месте человека в обществе.

Содержание повествовательной поэмы «Братья» разделено на 16 частей, составляющих внешний слой композиции. В каждой части нарративный фокус представляет динамическую картину социальной жизни относительно одного образа - трех братьев по отдельности или авторского «я». Первая, вторая, четвертая и заключительная шестнадцатая части - поэтические размышления о творчестве и времени - воспринимаются лирическими отступлениями. Диалогическая композиция третьей части определена спором двух старших братьев, оправдывающих свой образ жизни. Их отрицательные социальные портреты уточняются в этом эпизоде репликой младшего брата. Таким образом, в их диалоге автор подчеркивает не противопоставление, а сопоставление понятий единого ряда. Отсюда, на первый взгляд, безобидная реакция младшего брата превращается в композиционном разрезе в значительное определение, а именно, уточнение зеркальной композиции данной части. В целом третья часть, представляющая братьев, живущих в одном доме, воспринимается завязкой 
стихотворного повествования - началом их раздельного представления, с этого момента поэт «прослеживает» их жизненные пути в отдельности.

Пятая и шестая части посвящаются хронике жизни старшего брата Спиридона. Седьмая и восьмая части в таком же ракурсе представляют среднего брата - Гаврила. Приемы зеркальной композиции от локальной картины быта переходят в развернутое описание образа жизни с его глубокими социальными и психологическими представлениями. Девятая, десятая и двенадцатаячетырнадцатая части, также прослеживающие судьбы братьев, эти же приемы «превращают» в поэтический повтор-наслоение и тем самым развитие главной сюжетной линии доходит до кульминации, праздная жизнь некогда зажиточных молодых людей приводит их к печальному финалу - встрече в коридоре тюрьмы.

Одиннадцатая часть в повествовании о двух старших братьях выполняет функцию вставного сюжета. Здесь представлена жизнь младшего брата Андрея, который после того, как был выгнан из родного дома, только трудился, копил состояние и добился своего, стал богачом. Но его одолело скопидомство. Он превратился по отношению к родным братьям в «скупого богача». Этот сюжет в целом тоже выступает повтором-напоминанием реплики младшего брата в третьей главе, когда спорящие со своей точки зрения о «ценностях жизни» старшие братья выгнали его из родного дома.

Пятнадцатую часть можно назвать развязкой поэтического сюжета, где автор повествует об одинаковой участи трех братьев: старший умер от пьянства, средний, проиграв все состояние, пропал без вести, а младшего новая власть отправила в острог. В шестнадцатой части размышления автора заключают произведение.

Таким образом, контаминация приемов противопоставления и повтора в отдельных частях «рассказа в стихах» на макроуровне произведения реализуется в форме зеркальной композиции. При этом и повторы-наслоения, и зеркальные отражения эпизодов рождают третий смысл в качестве вставного сюжета о младшем брате, создавая композиционный эффект тройного отражения судьбы. Заключительное лирическое отступление усиливает эмоциональный мир произведения, что также воспринимается как повтор по отношению к предшествующим «вставкам от автора» - развитием лирического мотива одиночества. В лирических отступлениях образ автора в его обращениях к читателю усиливает реально-исторический контекст размышлений, в которых дискурсивным мотивом выступает тема отрешенности от своего времени, переходящая в сквозной мотив одиночества по отношению к теме произведения в целом. Отсюда вступительные части и заключение в организации кадров 
сюжетной детализации выполняют функции экспрессивных акцентов авторской позиции.

Авторский дискурс актуализируется и в названии произведения. Нейтральное значение слова «братья» («ини-бии») дополняется креативной версией художественного текста. Систематизация кадров внутреннего зрения (фокализация) построена на окказиональных смысловых повторах аналогичных явлений - родственных социальных пороков, близких по значению эпизодов жизни в судьбах не только братьев, но и самого автора.

\section{Контрольные вопросы и задания}

1. На основе анализа стихотворения «Судьба Священных гор»и поэмы «Разговор священных гор» определите понятия «лирический сюжет», «энзистенциональное сверхсобытие», «однопорядковые образы».

2. Определите диафорический ряд в поэмах А.И.Софронова, на основе этого обоснуйте степень и характер авторской обработки фольклорных образов и мотивов.

3. Докажите определение «Письмо отцу» - лирическая поэма». На основе характеристики опорных точек композиции поэмы опишите своеобразие композиционных приемов на микро- и макроуровне.

4. На основе анализа поэмы «Письмо отцу» и комментариев автора к этому произведению сделайте характеристику стиля поэта. Обоснуйте свои выводы сопоставительным анализом лирических произведений автора.

5. Какова степень сходств и отличий авторских отступлений в «Письме отцу» и в рассказе в стихах «Братья»?

6. Определите опорные точки композиции в рассказе в стихах «Братья» на примерах из текста. Какова степень психологизма в этом произведении?

\section{Упражнения и задания для СРС}

1. Обоснуйте степень сходства и различия диалогического и циклического принципов композиции на примере анализа поэм А.И.Софронова.

2. Сделайте развернутый анализ таких принципов композиции, как зеркальное отражение, сопоставление и монтаж на примере рассказа стихах «Братья».

3. Сформулируйте проблематику представленных произведений А.И.Софронова на уровне анализа композиции поэм и места и роли авторского начала в них.

4. Определите на основе анализа текстов, какие стилевые доминанты выступают показателем психологизма в лирических поэмах А.И.Софронова.

5. Сделайте сопоставительный анализ проблематики поэм А.Е.Кулаковского «Сон шамана» и А.И.Софронова «Разговор Священных гор». Определите на этой основе характер поэмного начала как показателя жанровых особенностей произведений.

6. Сделайте сопоставительный анализ поэм «Сон шамана» и «Письмо отцу», обоснуйте «жанровый код» произведений на уровне текстологии названий и опорных позиций композиции. 


\section{Литература}

1. Есин А.Б. Принципы анализа литературного произведения. - М.: Флинта-Наука, 2000 .

2. Кайда Л.Г. Композиционный анализ художественного текста. - М.: Флинта, 2000.

3. Каллер Джонатан. Теория литературы. Краткое введение. - М.: АСТ-Астрель, 2006.

4. Кожинов В.В. Художественная речь // Теория литературы. Т. 1. Литература. - М.: ИМЛИ РАН, 2005. - С. 283-334.

5. Максимова П.В. Жанровая типология якутской поэзии. - Новосибирск: Наука, 2002.

6. Романова Л.Н. Основные тенденции развития якутской поэзии XX века. Двадцатыетридцатые годы // Литература Якутии ХХ века. - Якутск: ИГИ АН РС (Я), 2005. - С. 101-145.

7. Слепцов П.А. Якутский литературный язык. Истоки. Становление норм. Новосибирск: Наука, 1986.

8. Тобуроков Н.Н. Якутский стих. - Якутск: Якутское кн. изд-во, 1985.

9. Тюпа В.И. Аналитика художественного. - М.: «Лабиринт»-РГГУ, 2001. 


\section{III глава. ПОЭМЫ П.А. ОЙУНСКОГО}

\section{1. Жанровые особенности драматической поэмы}

В своем развитии поэма, оставаясь особым жанром, часто допускает смещение и взаимопроникновение родовых и жанровых структур, что обогащает и совершенствует её. В 1970-е гг., когда высказывались прогнозы о путях развития жанра, подчеркивалась «психологизация поэмы» как неизбежный творческий процесс» (М. Арочко). Следствием этой растущей психологизации отмечалось интенсивное развитие драматической поэмы (Г. Марков, Г.П. Прошина). О необходимости «высокого драматического начала» в поэме утверждали и сами поэты (Н. Доризо). Так начал развиваться в многонациональной советской литературе особый жанр, включающий в себя свойства всех трех родов литературы и получивший название «драматическая поэма».

Термином «драматическая поэма» уже с конца XVIII - нач. XIX вв. обозначался особый тип стихотворно-драматических произведений, с доминирующей в них морально-философской проблематикой: «Натан Мудрый» Лессинга, «Дон Карлос», «Валленштейн» Шиллера и др. В определении жанра таких произведений использовался немецкий термин «Lesedrama» (драма для чтения). Жанр драматической поэмы получил наибольшую популярность в творчестве революционных романтиков (Байрон «Манфред», «Каин», «Небо и Земля», Шелли «Освобожденный Прометей» и др.). Однако со времен Гегеля к таким произведениям относились как к «неполноценным» драмам, нарушающим в той или иной мере законы сцены. Мнение, что «сам этот тип произведений обычно не относят к числу основных литературных жанров», было, очевидно, причиной невнимания к нему со стороны литературоведов (Г.А. Червяченко). Развитие драматической поэмы как жанровой формы прослежено в работах Г.А. Червяченко, А.Т. Васильковского, Г.П. Прошиной, некоторые аспекты жанра затронуты в статьях Ю. Марцинкявичюса, М. Чимпой, И. Аузинь.

По сравнению с лироэпической поэмой, которая при всей сложности содержания сохраняет стержневую монологическую форму, заключающую в себе авторский идейно-эмоциональный заряд, в драматической поэме мысль автора извлекается из напряжения, возникающего в столкновении мнений и характеров. Драматическая форма дает поэтам возможность преодолеть «замкнутость в самом себе»: внутренний спор объективируется в диалоге различных персонажей. А главным отличием драматической поэмы от жанров 
драмы является господство в ней философской проблематики над событийностью и изображением характеров.

Драматическая поэма имеет свои типологические особенности: вопервых, в ней обязателен конфликт, основанный на противоборстве идей; вовторых, обязательна стихотворная диалогическая форма, где жанрообразующая функция отводится монологам, сосредоточенности на одной проблеме или на одном герое; в-третьих, характерна структурообразующая функция ремарок.

Развитие жанра драматической поэмы в истории якутской литературы не всегда шло равномерно и плодотворно, как другие разновидности поэмы. Первые обращения к этому жанру сделаны П.А. Ойунским («Красный Шаман», 1925, «Туйаарыма Куо Светлолицая», 1930). В 1930-1940-е гг. к драматической поэме обратились такие поэты, как Таллан Бюрэ («Уолан Эрилик») и И. Чагылган («Нюргустай Куо»). Типологическую группу драматических поэм в современной якутской литературе представляют произведения, написанные в 80-90 гг. ХХ столетия (П. Тобуроков, И. Гоголев, Р. Багатайский, М. Тимофеев, Н. Винокуров-Урсун, И. Егоров). По сравнению с другими разновидностями поэмы, драматическая поэма в якутской литературе так же, как и в истории русской и национальных литератур России, является редким жанром, заявляющим о себе в периоды наиболее интенсивной жизни литературы, обусловленной активным периодом развития общественного самосознания. С другой стороны, данный факт может выступить показателем сложности жанра.

В якутском литературоведении драматическая поэма как особая форма революционно-романтической трагедии находит отражение в работах И.В. Пухова, В.А. Семенова, И.Г. Спиридонова, Н.Н. Тобурокова и др., как подвид эпической поэмы - в исследованиях П.В. Максимовой. Исследованию становления и развития драматической поэмы в якутской литературе как своеобразной жанровой формы посвящена работа Л.П. Григорьевой ${ }^{42}$.

Героический эпос олонхо представляет собой своеобразный «жанркладезь» в становлении и развитии якутской письменной поэзии вообще. И потому в формировании отдельных жанров литературы народный эпос выполняет роль художественной основы и является базой, на которой основывается восприятие нового. В этом отношении драматическая поэма выступает одним из ярких примеров художественной обработки фольклорных сюжетов, мотивов и образов, в целом представляющих характерный вид

${ }^{42}$ Григорьева Л.П. Драматическая поэма в якутской литературе: Композиция и система образов. - автореф. дисс. ... канд. филол. наук. - Якутск, 2004. 
рецепции народно-поэтического текста в живом процессе формирования жанров художественной литературы.

Генетическая связь нового жанра - драматической поэмы - с эпосом наблюдается в особенностях композиции, характеристике главных героев, систематике образов в целом. Произведения П.А. Ойунского по своим образным параметрам соответствуют именно драматической поэме, которая по своей жанровой данности выступает тем произведением, где национальное (форма, проблематика, система образов) и общечеловеческое (тема, идея) органически соединяются в художественной идее, образах и символических иносказаниях поэтической речи. В композиционной структуре и развитии сюжетного действия поэмы Таллан Бюрэ поэмное начало наблюдается в метафорических определениях времени через вспомогательные образы.

Содержание драматических поэм 1980-1990 гг. связывается с определенными общественно-историческими моментами, отражающими противоречия эпохи, что является жанровой закономерностью для данного вида произведений. Особенности композиционной структуры и систематики образов драматических поэм обуславливаются стремлением выразить глубокие социальные и философские проблемы времени.

Авторские ремарки зависят от содержания произведения и творческих целей и задач отдельного автора. Драматические поэмы отличаются краткостью картин и частой их сменой, нередко связанной и с переменой места действия (как в реальном, так и в символическом планах). И потому ремарки, в основном, приобретают роль авторского повествования. В целом отсутствие или минимальное использование ремарок в драматической поэме восполняется собственно содержанием монологов персонажей.

\section{Контрольные вопросы и задания}

1. Определите термины «литературный род», «жанр», «жанровая форма», «жанровая разновидность».

2. Что такое поэма? Назовите жанровые разновидности поэмы по родовой доминанте.

3. Дайте определение термину «драматическая поэма». Какие свойства драматического рода характерны в ней?

4. В чем заключается главное отличие драматической поэмы и драмы в стихах? Определите термины «лирическая драма», «поэтическая драма».

5. Какие свойства эпоса характерны для драматической поэмы?

6. Назовите типологические особенности драматической поэмы как жанровой разновидности поэмы. 


\section{Упражнения и задания для СРС}

1. Проследите историю развития драматической поэмы как жанра. Определите особенности ранней драматической поэмы.

2. В чем заключается сложность жанра драматической поэмы. Обоснуйте ответ, основываясь на анализе композиции одного произведения.

3. Определите функции ремарок в драматической поэме. В чем отличаются ремарки драматической поэмы от ремарок собственно драматических произведений?

4. Определите особенности диалогов и монологов героев драматической поэмы.

\section{Литература}

1. Васильковский А.Т. Жанровые разновидности русской советской поэмы 1917-1941. Опыт типологической характеристики. - Киев: Выща шк., 1979. - 199 с.

2. Коваленко С.А. Поэма как жанр литературы. - М.: Знание, 1981. - 110 с.

3. Кузьмичев И.К. Литературные перекрестки: Типология жанров, их историческая судьба. - Горький: Волго-вятское изд-во, 1983. - 208 с.

4. Лавлинский Л. Горизонты современной поэмы (проблемы жанра) // Вопросы литературы. - 1986. - № 4.- С.18-43 $206 \mathrm{c}$.

5. Поспелов Г.Н. Лирика среди литературных родов. - М.: Изд-во Моск. Ун-та., 1976. -

6. Прошина Г.П. Жанровое многообразие современной поэмы. - Ашхабад, 1982. - 55 с.

7. Хализев В.Е. Драма как род литературы. Поэтика, генезис, функционирование. - М.: Изд-во МГУ, 1986. - 259 с.

8. Червяченко Г.А. Поэма в советской литературе. - Ростов-на-Дону: Изд-во Рост. унта, 1978. - $192 \mathrm{c.}$

9. Чернец Л.В. Литературные жанры. Проблемы типологии и поэтики. - М.: Изд-во МГУ, 1982.- 192 c.

\section{2. Композиционные особенности драматической поэмы П.А. Ойунского «Красный Шаман»}

Над драматической поэмой «Красный Шаман» П.А. Ойунский работал в 1917-1925 гг. В течение этого времени несколько раз переделывал, дополнял, работал над языком произведения, а в феврале 1925 г. написал новые части: вступление (Аан маннайгы көстүүтэ) и эпилог (БүтүҮтэ), что в русском переводе представлено прологом, явлением третьим и четвертым последнего четвертого действия произведения. Эти дополнения - заклинание Красного Шамана (Кыһыл Ойуун кэп туонуута), сцена появления Кутурган Куо (Духа мировой скорби) и заключительная песня Хатан Тэмиэрийэ (Духа огня) - 
называются одними из значительных частей поэмы. Автор придавал особое значение «Красному Шаману»; он посвятил ему ряд статей и выступлений ${ }^{43}$.

С момента своего появления драматическая поэма «Красный Шаман» П.А. Ойунского вызвала особый интерес критиков и литературоведов. Разговоры о художественных особенностях поэмы продолжаются до настоящего времени. Исследование художественного своеобразия «Красного шамана» нашло отражение в работах известных якутских ученых, как В.А. Семенов, Г.С. Сыромятников, И.Г. Спиридонов, И.В. Пухов, А.А. Билюкина, Г.Г. Филиппов, В.Н. Протодьяконов, П.В. Максимова, В.Б. Окорокова и др.

Определение жанра произведения имеет весомое значение в понимании всего произведения. Самим автором это произведение определено как «олонхотойук» (букв. «песнь-олонхо»). В переводе на русский язык и в своих статьях на русском языке П.А. Ойунский называет свое произведение поэмой. В определении жанра «Красного Шамана» в критике имеются различные подходы. Многие определяют как драму, В.А. Семенов называет трагедией, H.M. Заболоцкий - драматической поэмой. Г.Г. Филиппов определяет жанр «Красного Шамана» как «тойук-диалог», созданный по традиции олонхо («олонхо ньыматынан айыллыбыт тойук-диалог») ${ }^{44}$. Однако большинством исследователей «Красный Шаман» принято считать драматической поэмой (И.Г. Спиридонов, А.А. Билюкина, П.В. Максимова). Как определяет В.Б. Окорокова, термином «олонхо-тойук» автор хотел подчеркнуть сложность и синкретический характер произведения: слово «олонхо» выступает показателем драматического начала произведения, а «тойук» - это то, же что и поэма. «Высокое героическое содержание, яркий поэтический язык, ориентированность на сценическую постановку произведения «Красный Шаман» - все это, и вправду, является показателем синтеза жанров», заключает В.Б. Окорокова ${ }^{45}$ (перевод на русский язык наш - Л.Г.). Таким образом, термин «драматическая поэма» вполне соответствует с авторским определением «олонхо-тойук».

Развитие сюжетного действия. Драматическая поэма П.А.Ойунского «Красный Шаман» состоит из вступления, четырех частей и эпилога. Развитие сюжетного действия произведения можно представить следующим образом:

\footnotetext{
${ }^{43}$ Ойунский П.А. Избранные произведения. В 2-х т. Т. 2. - Якутск: Якут. кн. изд-во, 1975. - С. 288-290, 368-370, 371-373.

44 Филиппов Г.Г. П.А.Ойуунускай айар стилигэр бэлиэтээһиннэр (К творческому стилю П.А.Ойунского) // П.А.Ойунский: Взгляд через годы. - Новосибирск: НИЦ ОИГГМ, 1998. - С.159.

${ }^{45}$ Окорокова В.Б. «Күөдьүйбүт тыл, дьүһүннэммит санаа...» Творчество П.А.Ойунского. - Якутск, 2003. C.76.
} 
I. Экспозищия. Песни и танцы духов деревьев и трав с духом земли Эбэ Хотун; монолог Красного Шамана о своем становлении шаманом (1-3 явления первого действия).

II. Завязка действия. Диалоги косарей и Красного Шамана (4 явление первого действия).

III. Развитие действия. 1) Камлание Красного Шамана (1 явление второго действия); 2) приход Шамана Сасыл (2-3 явления второго действия); 3) сон Орос Бая (1-2 явления третьего действия); 4) «праздник» в честь сватовства сына Улутуяра к Айыы Куо (3-6 явления третьего действия).

IV. Кульминация. Смерть Айыы Куо. Разрешение конфликта между Красным Шаманом и Орос Баем (7 явление третьего действия).

V. Развязка. Заклинание старинного якутского ножа.

VI. Эпилог (финал). Появление Кутурган Куо, монолог Хатан Тэмиэрийэ.

Во вступлении мы видим Красного Шамана пасмурным вечером, одиноко стоящего, опустившись на одно колено, возле шалаша. Гремит гром, сверкают молнии. Красный Шаман, ударяя в бубен, говорит заклинание: он размышляет о своем предназначении, о своей роковой судьбе. Красный Шаман верит предсказанному жизненному пути борьбы за угнетенных и стремится к тому, чтобы его заклинания прозвучали «добрым набатом». Но, «стоя над миром восьмигранным, стон его слыша ухом тревожным», Шаман сомневается в одном:

«Ким, саныыр санаатын саргы иннигэр, «Будет ли добрым помянут словом Кырыыска ылларбыт кыра дьонун Өлбөт өрөгөй өйүн сырдатан, Өрө көтөБөн, ыллыгын ыйбыт, Өркөн-төлөн илбистээх идэнэн Өлбөт өрөгөй тылын тыыннаабыт, Айар санаатын күүһүн көрдөрбүт Аан дайдыбар аата ааттаныа дуо?!» ${ }^{46}$

Бурю поднявший страстным зовом, Родине жизнь свою посвятивший, Робость невольников победивший, В сердце им вливший стойкость, решимость,

Веру в величье и несокрушимость Бьющихся с ложью, Бесправьем и злом?» ${ }^{47}$ [с. 84$]$

«Эта мысль в своем развитии усиливает противоречивость, сложность образа Красного Шамана, - отмечает П.В. Максимова, - и входит в русло основного сюжета трагической линией его судьбы, углубляя философскую идею произведения» ${ }^{48}$.

\footnotetext{
46 Здесь и далее текст на як. яз. дается по изданию: Ойунский П.А. Сочинения. Том 1. Стихи, переводы, драматические поэмы. - Якутск, Нац. кн. изд-во, 1992. - 336 с.

47 Здесь и далее текст на русс. яз. (пер. В. Корчагина) дается по книге: Ойунский П. Стихотворения и поэмы: пер. с якут. / Сост. Н.Сивцева. - М.: Худож. лит., 1993. - 271 с.

48 Максимова П.В.Жанровая типология якутской поэзии: Вопросы эволюции и классификации форм. Новосибирск: Наука, 2002. - С. 75.
} 
В первом действии поэмы выводится на сцену дух земли Эбэ Хотун и духи трав, деревьев, которые кланяются Эбэ Хотун, пляшут и поют традиционную песню, славя расцвет природы. Проснувшись, Красный Шаман вспоминает о посвящении в шаманы, рассказывает о своей борьбе против Орос Бая, «ставшего владыкой - хозяином земли». Основным событием первого действия драматической поэмы становится приход работников Орос Бая косарей. Они изнурены трудом, голодны. Красный Шаман кормит их, поит кумысом. Косари благодарны ему, но, чтобы Орос Бай не догадался об угощении их, вытирают губы золой. Бедняки жалуются на свой тяжкий труд, вечный голод, но не знают, кто повинен в их горестной судьбе. Красному Шаману прискорбно, обидно, что народу «даже видимое не видно», «даже повторенное стократно до сих пор непонятно». Он еще раз разъясняет, что повинен в их тяжелой судьбе Орос Бай, и лишь уничтожив его можно «к солнцу вывести человека». Первое действие заканчивается призывом Красного Шамана воспрянуть ото сна:

«Уһугун, өйдөн, икки атахтаах!

Уһугун, өйдөн, хара кырыыстаaх!!!

Эн хааннар хахай хаана хамнаатын,

Эн кырыыскар көнүл уота умайдын...

Хааннаах алдьархай кэлэрэ буолла,

Хааннаах кырыыс дьайа туолла»
«Очнись, опомнись, угнетенный!

Озлобься, нищий, угнетенный!

Найди в себе для битвы силы, Наполни львиной кровью жилы, Верь: с плеч своих ты сбросишь бремя.

Великое приходит время!» [с. 93]

[c.206]

Второе действие. Красный Шаман в своей юрте, в ритуальном убранстве и с бубном, камлает перед очагом. Он обращается к своим шаманским божествам и духу очага, прося их придать ему силу перед отправлением в дорогу для совершения подвига, для низвержения Орос Бая. Заметим, что это камлание Красного Шамана перекликается с обязательным заклинанием (или песней Илбиса) богатырей айыы в олонхо перед отправлением в героический поход (Нюргун Боотур, Юрюнг Уолан).

Прибывает Шаман Сасыл со своим помощником и сообщает о решении Орос Бая выдать свою дочь Айыы Куо за небесного витязя, могущественного Орулуос Дохсуна, чтобы «защитить» и «улучшить Средний мир». Красный Шаман, твердо решивший уничтожить Орос Бая, дает отказ на предложение пожилого Шамана Сасыл не противостоять Орос Баю.

Tретье действие происходит в доме Орос Бая. В ремарке подробно описывается внутреннее убранство дома, свидетельствующее о богатой жизни хозяина. К Орос Баю приходит Шаман Сасыл и сообщает о неудачном разговоре с Красным Шаманом. Орос Бай просит истолковать свой сон: ему приснилось, будто могучий орел заклевал белую лебедь. Шаман Сасыл 
пытается растолковать сон в пользу Орос Бая: Орулуос Дохсун женится на его дочери, он унесет ее душу. Орос Бай сомневается, что небесный витязь может обернуться орлом, он скорее мог бы быть соколом. Однако он все же решается выдать дочь и велит «пригласить гостей, приготовить тюсюлгэ». Собираются родоначальники десяти улусов, почтенные богачи-тойоны с женами, прекрасные юные девушки и юноши; все приветствуют Орос Бая, начинается праздник в честь встречи жениха прекрасной Айыы Куо. Появляется Айыы Куо в сопровождении двенадцати девушек-наперсниц, которые, взявшись за руки, ходят вокруг нее и поют хоровую песню с пожеланием счастья в замужестве. В этот момент неожиданно раздается гром и на середину юрты падает бубен. Айыы Куо с пронзительным криком замертво падает на бубен. Шаман Сасыл узнает бубен Красного Шамана. Знамением победы Красного Шамана над Орос Баем и Шаманом Сасыл выступает гибель Айыы Куо, которая в эпических произведениях фольклора всегда является символом красоты, чистоты, идеалом жизни на земле.

Четвертое действие состоит из двух явлений: первое - монолог Духа Огня Хатан Тэмиэрийэ, второе - монолог Красного Шамана (заклинание, клятва). Действие происходит в холодный зимний вечер, чем подтверждается наступление еще более тяжелой жизни. Красный Шаман не радуется своей победе над Орос Баем, его победа не принесла желаемых результатов: на земле все еще царит Зло. Теперь он убежден, что одному ему не по силам разрушить Зло, не пришло тому время - еще рано; существующий гнет и бедность могут одолеть только сами обездоленные, сами угнетенные:
«Солону-сокуону, сору-муну
«Кто ж цепи рабства сбросит, разорвет?
Солбонутуоъа сордоох-муннаах,
Соххор доқолон кулут аймаБа»
Кто уничтожит в мире зло и гнет?
[с.221] Ты, раб!
Ты, угнетенный!
Только ты!» [c.108]

Красный Шаман твердо убежден в том, что наступит конец «железному веку» (его веку - жестокому, кровожадному), и тогда придет время мирной и счастливой жизни. Ради этого будущего нужно бороться; теперь Красному Шаману ясно одно: ему предназначено пробудить народ, открыть ему глаза и привести к борьбе за свое счастье. И Красный Шаман заклинает старинный якутский нож: «В кровавой омывайся жажде, / Врывайся в битву, бей отважно, / Рычи, ломая ребра вражьи, / Рушь, режь, рази и зло и ложь! / Свергай их власть в бою последнем! / Сверкай во тьме лучом победным! Свет, радость дай забитым, беднымм! / Страданье, горе уничтожь!» [с.109]. 
И ударяя колотушкой о бубен, Красный Шаман клянется «яркостью родного очага, языками хлесткими его, зорями, горямими вдали, бурями и муками земли», что больше не вернется к суеверьям, что стал он их сильней. Красный шаман твердо уверен в наступлении благословенной счастливой жизни, что клянется и «содеянным грехом своим», и всем святым, что есть у него («цветеньем и теплом», «чертами женщины, чьи взоры ярче вешних дней»). Заканчивает Красный Шаман так:

«Хара кырыыс халбарыйыақа,

Хааннаах хабала алдьаныақа,

Икки атахтаах - улахан,

Икки атахтаах - тангара...» [c.223]
«Прервется боль, сгорит беда,

Придут счастливые года,

Испепелят жестокий век -

И станет богом человек!» [с.110]

В финале произведения появляется Кутурган Куо, «дух, олицетворяющий народную скорбь и мудрость Вселенной». Появившись из далекого будущего, Кутурган Куо убеждает Красного Шамана в том, что человеческий разум выше всепобеждающей силы и «разумом смерть он победил». Кутурган Куо и Красный Шаман вместе поют песню - гимн Человеку. Содержание этой песни раскрывает историю трех веков: уход века баев-эксплуататоров (век Орос Бая), конец «железного века» (век Красного Шамана, век борьбы), наступление вольной и счастливой жизни, в которой человек победит смерть своим разумом (век, о котором говорит Кутурган Куо).

Красный Шаман отрекается от шаманства; его последний монолог становится прощальной речью:

«Оһоллоох орто аан дойду

Одьунаас улуу ойууна

Ойууннуурбуттан уурайдым.

Үөһээ-аллараа биистэрэ

Үөлэспин өнейбөтүннэр,

Кырыыс кыйданнын,

Кыырар уурайдын...» [с.226]

Сюжет произведения завершает монолог Духа Огня Хатан-Тэмиэрийэ, символизирующего неугасающее пламя жизни на земле. Он опечален смертью великого шамана.

Связь произведения с народными преданиями и героическим эпосом олонхо. Как отметил сам П.А. Ойунский, в основу «Красного Шамана» были взяты две легенды: 1) противостояние знаменитому роду Оросиных Шамана Добуна, по преданию истребившего своими заклинаниями весь этот род; 2) старинное предание о Кудангсе, выдавшем свою дочь за сына Улуутуйар Улуу Суорун Тойона (Надменный Великий Непреклонный Господин, по якутской мифологии - глава небесных злых существ абаасы), для смягчения 
болезней, ниспосланных с небес из страны Улутуяра. И как отметил автор: «Вместо Оросина, совмещающего идеологию Кудангсы, появился Оруос Бай, вместо Добуна - Красный Шаман» ${ }^{49}$. И.В. Пухов подчеркивает, что связь «Красного Шамана» с якутскими преданиями в основном сюжетнотематическая: «Сюжеты народных преданий стали основой всех событий «Красного Шамана». Опираясь на них, развивая их, оснащая их современным жизненным материалом, автор создал свою поэму» ${ }^{50}$.

На связь «Красного Шамана» с героическим эпосом олонхо указывал и сам автор, определив жанр произведения, как «олонхо-тойук». Влияние олонхо на поэтику «Красного Шамана», как отмечают исследователи, главным образом заключается в общности идеи борьбы светлых сил мироздания с силами зла за освобождение народа от рабства и в характеристике образа главного героя.

Образ главного героя. Образ Красного Шамана глубоко связан с народными представлениями и является идейно-стилевым, структурнообразующим центром всего произведения. Борьба главного героя против гнета и власти темных сил за освобождение и счастье народа, поставленного самой жизнью и судьбой в эпицентр событий, составляет содержание драматической поэмы.

В описании высокого предназначения героя и его облика П.А. Ойунским использован гиперболический стиль героического эпоса. Красный Шаман, как и герои олонхо, характеризуется духами деревьев и трав, наделяясь сверхъестественными свойствами и обликом:

$\begin{array}{ll}\text { «Үргэл сулус үктэллээх, } & \text { «Скалы слышат, как он дышит - } \\ \text { Үгүс-өлгөм күүстэрдээх } & \text { Силы набирается. } \\ \text { Кыһыл Ойуун обургу } & \text { Он разлегся во весь рост, } \\ \text { Кытаанахтык утуйбут. } & \text { Он стопой достал до звезд - } \\ \text { Орой-буурай охсуста, } & \text { И Стожары задрожали, } \\ \text { Орто дойду долгуйда } & \text { Искрами рассыпались... } \\ \text { Үллэн түллэн табыста» [с.200] } & \text { Переплавятся миры, } \\ & \text { Перепашутся бугры» [с.87] }\end{array}$

Подобно тому, как богатырь Нюргун Боотур был свыше предназначен стать защитником людей племени айыы аймага от злых сил, Красному Шаману также предназначено стать в защиту угнетенного народа, представленного образами косарей Орос Бая. Как отмечает А.А. Билюкина, образ Красного Шамана представляет собой «аналог образов богатырей-защитников

\footnotetext{
${ }^{49}$ Ойунский П.А. Собр. соч. в 7 т. Т.7 - Якутск, 1958-1962. - С.118.

${ }^{50}$ Пухов И.В. «Красный Шаман» П.А.Ойунского и якутский фольклор // Пухов И.В. От фольклора к литературе. Сб. статей. - Якутск: Кн.изд-во, 1980. - С. 89.
} 
человеческого рода из олонхо» ${ }^{51}$. Красный Шаман наделен главными чертами положительного героя олонхо: он честен и смел, бескорыстен и целеустремлен. Борьба для него - смысл жизни, его стихия. Вместе с тем образ Красного Шамана отличается от образа эпического героя «своим внутренним содержанием, то есть большей реальностью, приближенностью к практическим делам общества» ${ }^{52}$. Герой П.А. Ойунского стремится показать «путами сдавленному народу путь, на котором он найдет свободу».

Особую роль в драматической поэме играет то, что ее герой - шаман властитель умов и сердец, представитель духовного начала, и он оказывается защитником обездоленных людей в годину испытаний. В олонхо нет образов шаманов, однако, в нем заметная роль отводится образам Удаганок (айыы и абаасы). Шаман П.А. Ойунского - особенный шаман: не белый и не черный по традиции, а красный - «по аналогии с символическим красным цветом революции» ${ }^{53}$. Отличный знаток шаманизма, автор ряда работ и произведений с участием шаманов, П.А. Ойунский в создании «Красного Шамана» «руководствовался не буквальной достоверностью факта, не подлинным сходством с шаманскими обрядами и требованиями ритуала, а идейноэстетическими потребностями художественного произведения» ${ }^{54}$. Шаман П.А. Ойунского - это героический образ. Автор обошел почти все культовые, обрядовые моменты шаманского камлания. Он стремился создать лишь впечатление достоверности в целях художественной, эстетической убедительности поэмы. Это - наличие шаманского костюма и бубна. Звуки бубна «дом-эрэ-доом» в драматической поэме повторяются в узловых моментах монологов героя, они «заканчивают» мысль шамана звуковым аккордом, а также автором сохраняется время традиционного шаманского камлания - вечер.

Монологи Красного Шамана являются важными составляющими драматической формы, в них раскрываются его посредническая роль между мирами, божествами и людьми, его концепция борьбы за счастливую жизнь. Раздумья о трагической судьбе угнетенного народа, о путях и средствах спасения его от гибели приводят главного героя поэмы к широким обобщениям философского характера, что проявляется в особенностях его речи: в его подчеркнутом тяготении к сложному предложению с периодическим построением, с обилием развернутых метафор, ярких эпитетов. Такая интонационно-синтаксическая форма построения речи типична для языка

\footnotetext{
${ }^{51}$ Билюкина А.А. Из истории литературно-художественной мысли Якутии ХХ века. - Якутск, 2002. - С. 65.

${ }^{52}$ Спиридонов И.Г. Ойунский и наше время. - Якутск: Бичик, 2003. - С. 84.

${ }^{53}$ Билюкина А.А. Указ. соч. - С. 64.

${ }^{54}$ Пухов И.В. Указ.статья. - С. 93.
} 
Красного Шамана, и обнаруживается в первом же предложении монолога героя в прологе произведения:
«Алдьархайдаах аан дайдыбар,
«Стоя над миром восьмидорожным,
Адырқаннаах ауыс аартыгар
Кырыыстаах сата кынаттаах
Кыһыл Ойуун, улуу дьаалы,
Хааннаах далай ытыспынан
Харана норуот харађын аһан,
Көрбөт харађын көрдөрөн
Көнүлүн уотун уматыам дуо?»
Стон его слыша ухом тревожным, Зная коварство сил его темных, Зренье даруя глазам угнетенных, Все свои думы связав с бедняками, - В сердце народа вдохнул ли пламя Яростной битвы с гнетом, обманом Я, именуемый Красным Шаманом?»

\section{Речь Красного Шамана} народнопоэтическими речениями насыщена самыми разнообразными многокрасочной гиперболической следующем отрывке:

«Алдьархайдаах айыым аймађын

Ат гынан айааһаабыт-мииммит, Эрэйин-буруйун элбэппит, Эрийэн-мускуйан олорбут, Орто дойду баһылыга буолбут Оруос Баай обургуну

Сирдээх халлааны илиитигэр туттараары, Сиигин-симэһинин куртақар куттараары, Сатыы соллоно санаа буллардақа. Саллайар сааспар саха манныгын Күөн көрсөн, күрэстэһэ илигим... Күн сирин күүстээБин кытта Күрэс былдьаһар одун санаабын, Мөккүөр бөБөбүн мөлтөппөппүн, Мөккүөр бөБөбүн төннөрбөппүн!..» [c.210]

\author{
«... Рассуди ты нас, взгляни-ка! \\ Расходился твой владыка: \\ Беднягу согнул он спину, \\ Бьет людей он, как скотину, \\ Сеет беды да напасти... \\ Слышишь? Жажда высшей власти \\ Одолела Орос Бая: \\ Он, ручищи распуская, \\ Своему служа лишь благу, \\ Сок земли и неба влагу \\ Слить решил себе в утробу!.. \\ Нет, не погашу я злобу, \\ Не сниму свои проклятья, \\ Не устану враждовать я \\ С самым сильным из двуногих, \\ С самым страшным из двуногих - \\ С тем, кто людям сел на шею: \\ Сброшу прочь и в прах развею!..»
} [c.97]

«Эта выразительная реплика по своему смыслу и по своей тональности не столько повествует, сколько негодует, убеждает и призывает к решительной борьбе, - пишет В.А. Семенов. - Она соответствует психологической и социальной природе главного героя, раскрывает самое важное, существенное в его мыслях, чувствах и поступках - сильную ненависть к поработителю трудового народа и готовность к непримиримой борьбе с врагом. И в то же время эта реплика действенна, она, вытекая из создавшейся драматической 
ситуации, обостряет сюжетный конфликт до такой степени, что неминуемо должна наступить решительная схватка между Кысыл Ойуном и Орос-Баем» ${ }^{55}$.

В монологах Красного Шамана можно увидеть некоторые черты, характерные для монологов героев олонхо, как, например, самохарактеристика героев, возвеличивающих себя. Так, Красный Шаман говорит о себе: «Yөһэттэн үһүллүбүт, / Үрдүктэн ыйыллыбыт, / Үргэл сулус үктэллээх, / Өрөгөйдөөх халлаан өксөкүтэ / Өлбөт үнэр танаралаах, / Алдьархайдаах Аан дайды / Алгыстаах атыыр о5уһа, / Аам-дьамаан дьааһыйдым» [с.207] («Верхними небесами вскормленный, / Высшим роком сверху назначенный, / На плеядах пристанище имеющий, / Великий шаман Бедового мира / Могучий бык - охранитель я, / Бессмертный Бог - покровитель мой - / Бесконечного неба Орел святой» ${ }^{56}$ ).

Женские образы. Введенные автором в драматическую поэму три женских образа - Эбэ Хотун, Айыы Куо, Кутурган Куо - имеют композиционное значение. Они помогают понять сущность образа Красного Шамана и раскрыть идею драматической поэмы.

Образ духа земли Эбэ Хотун введен автором, скорее для того, чтобы воспеть красоту окружающей природы родной страны героя (вспомним, в олонхо какова страна, таков и сам герой), где в будущем с помощью Красного Шамана «исполнятся мечты» всех и Средний мир «оденется в цветы». Таким образом, образ Эбэ Хотун характеризует ту сторону образа Красного Шамана, которая связана со светлым будущим.

Второй женский образ - образ Айыы Куо. Айыы Куо в драматической поэме появляется один раз: в шестом явлении третьего действия и всего лишь для того, чтобы умереть, тем самым подтвердить победу Красного Шамана над Орос Баем. Однако роль этого эпизодического персонажа, являющегося во всех произведениях фольклора символом красоты, чистоты и счастья, весьма значительна. Для Орос Бая замужество Айыы Куо с Небесным Витязем Орулуос Дохсуном - единственное средство для дальнейшего укрепления своей власти, а для Красного Шамана ее гибель - единственный путь для спасения угнетенного Орос Баем народа. И как отмечает П.В. Максимова, «по отношении к ней Красный Шаман и Орос Бай проявляют жестокость, представляя две противоборствующие идеи. В своих действиях они оба выступают носителями роковой судьбы, ибо их время, их мир - период коренного перелома устоев жизни, что в поэме символизировано образом «разгоряченного коня, сажей,

55 Семенов В.А. Фольклорные сюжеты и мотивы в творчестве П.А.Ойунского. - Якутск: Якут. кн. изд-во, 1966. - С.70.

${ }^{56}$ Перевод Е.Сидорова // Газ. «Якутия». - 1992. - 23 сентября. 
кровью, потом отягченного», который «скачет, бьется на кругу широком, след свой стелет огненным потоком» ${ }^{57}$.

Драматический конфликт между Красным Шаманом и Орос Баем, как бы исчерпан. Однако, как далее мы увидим, гибель Айыы Куо, не приводит к той жизни, о которой мечтает Красный Шаман для народа. Именно эта трагедия, гибель невинной девушки, осуществленная доступными ему магическими средствами, отрезвляет его: Красный Шаман понимает свое истинное предназначение - привести народ к борьбе (заклинание ножа).

Третий образ - образ Кутурган Куо, «духа, олицетворяющего народную скорбь и мудрость Вселенной», подтверждает достижение Красным Шаманом своей цели, поставленной еще в прологе произведения: «Икки aтахтаax тилиннэ! / Икки атахтаах тилиннэ! / Өлөру өйүнэн кыайда, / Өлөртөн өлбөт буолла» [c.224] («Это сбылось! Это сбылось! / Раб пробужден, полон он сил, / Разумом смерть он победил!» [c.111]). Кутурган Куо вместе с Красным Шаманом поет песню о будущей счастливой жизни. Как отмечает в другой работе П.В. Максимова, из трех женских образов только Кутурган Куо по настоящему приближается к Красному Шаману - «кланяется и, превратившись в дым, исчезает». И только с помощью образа Кутурган Куо, можно понять истинное содержание двух других женских образов (Эбэ Хотун, Айыы Куо). Красный Шаман в начале произведения чувствует и знает теплое отношение Эбэ Хотун к нему. В кульминационной части поэмы Айыы Куо он воспринимает через ее Отца - Орос Бая - продолжением рода которого она является ${ }^{58}$.

Своим появлением каждая из этих образов - Эбэ Хотун - Айыы Куо Кутурган Куо - дает образу Красного Шамана иное качество: герой переходит на новый уровень, на новую ступень, развивается и совершенствуется его «идея»:

1. Из пролога мы узнаем о предназначении Красного Шамана, о его роковой судьбе и о целях, поставленных перед ним. Красный Шаман - пророк.

2. Появление Эбэ Хотун и ее песню («Слейтесь, молния и гром! / Славу силе мы поем!») Красный Шаман не видит и не слышит, он спит. Но он чувствует теплоту родной земли, ее поддержку в его нелегком «деле». И как в подтверждение этого приходят косари, образы которых носят и реальный, и символический характер. Они представляют собой весь образ угнетенного народа. Получив благословление родной земли (Эбэ Хотун) и самой

\footnotetext{
${ }^{57}$ Максимова П.В. Указ. соч. - С. 76

${ }^{58}$ Максимова П.В. Жанровая типология поэзии П.А.Ойунского (на як. яз) // Творчество П.А. Ойунского: сб. статей. - Якутск: Изд-во ЯГУ, 1993. - С. 34-35
} 
обездоленной части Человечества (косари), Красный Шаман становится более сильным, уверенным в своих действиях: он думает, что знает решение проблемы, борьбы Добра со Злом. Он должен «уничтожить душу Орос Бая».

3. Смерть Aüblbl Kуо заставляет Красного Шамана понять смысл борьбы - он убеждается в том, что бороться должны сами угнетенные. Теперь его цель пробудить народ, привести к борьбе (заклинание ножа): Красный Шаман просветитель - вот истинное его предназначение.

4. Появление Кутурган Куо - это подтверждение достижения Красным Шаманом своей цели именно как просветитель. Он отрекается от шаманства. Совместная песня Красного Шамана с Кутурган Куо - гимн Человеку - вера в Разум человека. Красный Шаман верит в «возможность всеобщей гармонии, возможность счастья для всех, без взаимного самоистребления» 59 . Таким образом, именно образом Кутурган Куо достигается смысловое и композиционное завершение важнейшей идеи драматической поэмы - идеи о наступлении вольной и счастливой жизни, где будет торжествовать Справедливость и Разум.

Образы Орос Бая и Шамана Сасыл. Орос Бай характеризуется Красным Шаманом, как «владыка, хозяин земли, в людей вселивший страх», «самый сильный из двуногих, самый страшный из двуногих». Как отмечают исследователи, с одной стороны образ Орос Бая представляет собой образ реального эксплуататора народа, головы десяти улусов, с другой символизирует идею старого века, вступающего с «железным веком» в единоборство ${ }^{60}$.

Описанию быта и действий Орос Бая в драматической поэме посвящено полностью третье действие. Предыстория этого образа заключается в монологах Красного Шамана. С самого начала произведения он характеризуется как антипод заглавного героя. В ремарках подробно описываются внутреннее убранство дома Орос Бая: «Күһүн. Оруос Баай дьиэтэ. Суоруулаах балақан. Айгыраабатын диэн эркинин аайы аБыстыы баараБай-балтаххай баБаналардаах. Айгыраспыт-ханыраспыт, оһуор ойуулаах алтан көхөлөрдөөх. Ойуулаах-оһуордаах сүлүүдэ түннүктэрдээх. Бастын оронноро бөрө тириитэ олбохтоохтор, атах оронноро эһэ тириитэ сабыылаахтар. Үстүу атахтаах төгүрүк сандалы манан остуоллар туругуран тураллар. Ханас диэки Хара дьиэ аана көстөр» [с.211-212]. («Осень. Балаган Орос Бая, сооруженный из оструганных бревен. Вдоль каждой стены - по восемь прочных, массивных столбов. На столбах - медные крюки-вешалки со

\footnotetext{
${ }^{59}$ Сидоров Е. Трагедия Красного шамана // Якутия. - 1992.- 23 сентября.

${ }^{60}$ Протодьяконов В.Н. П.А.Ойуунускай айымньыларын 8-с кыл. үөрэтии: метод. пособие для учителя. Якутск: Кн. изд-во, 1982. - С.30.
} 
всевозможными украшениями. Слюдяные окна испещрены узорами. Нары покрыты волчьими и медвежьими шкурами. Слева видна дверь черного балагана») [с.99].

В этом действии автором с помощью ремарок подробно описывается быт, уклад жизни, власть Орос Бая, и тем самым подчеркивается, за что он борется. Тут же укажем связь ремарок драматической поэмы с героическим эпосом олонхо. Приведем пример из того же третьего действия: «Уон улуус бэртэрэ бастын баайдара, куба курдук үтүө хотуттара, кыталык курдук мааны кыргыттара, туруйа курдук туйгун уолаттара киирэллэр. Бары сиргэ сүгүрүс гыналлар, уруйдууллар» [с.215]. («Входят гости: родоначальники десяти улусов; почтенные богачи-тойоны с женщинами; прекрасные девушки, подобные стерхам; стройные юноши, подобные журавлям. Гости с низкими поклонами приветствуют Орос Бая») [с.102]. Для характеристики гостей П.А. Ойунский использует традиционные народно-поэтические эпитеты и сравнения: он передает старинные национальные обычаи встречи гостей со знатным хозяином дома; подчеркивается огромный авторитет и сила власти Орос Бая.

Вместе с тем в отличие от ремарок поэмы «Туйаарыма Куо Светлолицая», ремарки «Красного Шамана» более реалистичны, в них передается самобытная картина якутского национального быта, нравов, обычаев и народных поверий. В то же время ремарки произведения в целом романтически ярко оттеняют звуко-световые эффекты действия.

В первом монологе из уст «ставшего владыкой, хозяином земли» Орос Бая слышны нотки растерянности, страха и обреченности при раздумье о наступающем «железном веке» - «жестоком, когтистом, клыкастом» - при мысли о Красном Шамане, способном «взять верх». Об обреченности борьбы Opoc Бая свидетельствует введенный автором сон: будто орел заклевал прекрасную лебедь.

Сторонником Орос Бая, его верным и преданным советчиком является Шаман Сасыл. В противоположность Красному Шаману, этот шаман очень хитрый, что способен лгать, обмануть любого: и врага, и союзника. Он ловко приспосабливается к любым жизненным обстоятельствам (сцены с Красным Шаманом, растолкование сна Орос Бая и т.д.). Содержание и тон речи Шамана Сасыл быстро меняются в зависимости от обстановки. Являясь сторонником Opoc Бая, он как бы дополняет иным качеством его идею - Ложь и Обман выступают в поэме оружием старого века.

В «Красном Шамане» П.А. Ойунского наблюдается также и влияние опытов мировой и русской литературы. По мнению исследователей, «дух отрицания старого уклада жизни сближает образ Красного Шамана П.А. Ойунского с Демоном М.Ю. Лермонтова, с Фаустом Гете. Ойунский берет у этих произведений тот бунтарский, свободолюбивый дух, которым они 
проникнуты, и развивает его до героического, революционного пафоса, особенно необходимого в период революционного переустройства мира» ${ }^{61}$.

\section{Контрольные вопросы и задания}

1. На основе анализа "Красного шамана" определите такие жанровые особенности драматической поэмы, как значимость авторского начала и особую систематику образов.

2. Имеют ли ремарки значение в определении опорных точек композиции?

3. Почему, на ваш взгляд, П.А. Ойунский определил жанр “Красного Шамана” как “олонхо-тойук”?

4. В чем заключается главная идея "Красного Шамана”? Определите значение образа Кутурган Куо.

5. Какова роль фольклорных средств выразительности в поэме? Определите ее на уровне поэтического языка и особенностей стиха.

\section{Упражнения и задания для СРС}

1. Сравните сюжетные линии поэмы “Красный Шаман” и легенды “Великий Кудангса" и определите своеобразие композиции драматической поэмы.

2. Определите функции и роль ремарок в драматической поэме «Красный Шаман».

3. Определите влияние в «Красном Шамане» опыта мировой и русской литературы. Обоснуйте свои выводы на основе сравнительно-сопоставительного анализа образа Красного Шамана и Демона М.Ю.Лермонтова, Фауста Гете.

\section{Литература}

1. Максимова П.В. Жанровая типология якутской поэзии: Вопросы эволюции и классификации форм. - Новосибирск: Наука, 2002. - 255 с.

2. Окорокова В.Б. «Күөдьүйбүт тыл, дьүһүннэммит санаа..»: Творчество П.А.Ойунского - Якутск, 2003. - 136 с.

3. П.А.Ойунский: Взгляд через годы. - Новосибирск: НИЦ ОИГГМ, 1998.

4. П.А.Ойуунускай айар үлэтигэр бэлиэтээһиннэр: сб. статей. - Якутск, 1993.

5. Протодьяконов В.Н. П.А.Ойуунускай айымньыларын 8 кылааска үөрэтии - Якутск: Кн. изд-во, 1982. - 64 с.

6. Пухов И.В. От фольклора к литературе. сб. статей. - Якутск: Кн.изд-во, 1980. - 126с.

7. Семенов В.А. Творчество П.А.Ойунского и становление социалистического реализма в якутской советской литературе. - М.: Наука, 1980. - 220 с.

\section{3. Особенности композиционной структуры драматической поэмы П.А. Ойунского «Туйаарыма Куо Светлолицая»}

Как отмечают исследователи, «в отношении Ойунского к олонхо органически слиты эрудиция исследователя и жар поэтического вдохновения» ${ }^{62}$.

\footnotetext{
${ }^{61}$ Башарина 3.К. Взаимодействие русской и якутской литератур. - Якутск: Изд-во ЯГУ, 1992. С.41
} 
И потому П.А. Ойунскому не свойственно было не чувствовать и не сознавать драматическую природу конфликта якутского героического эпоса и ярко выраженные в нем элементы драматического искусства. Подтверждением того, что он не обошел вниманием сценические возможности, заложенные в произведениях устного народного творчества, явилось создание поэмы «Туйаарыма Куо Светлолицая». П.А. Ойунский «на остроконфликтной основе олонхо создал цельное и ёмкое оригинальное произведение» ${ }^{63}$.

«Туйаарыма Куо Светлолицая» П.А. Ойунского еще в феврале 1928 г. была поставлена на сцене Якутского театра. Известно, что П.А. Ойунский «одобрил первый опыт сценического воплощения олонхо и назвал этот почин важным для развития якутской драматургии, якутского театра. Вместе с тем автор указал на серьезные недостатки в постановке пьесы и дал ценные указания по поводу исполнения той или иной роли» ${ }^{64}$. На основе этого произведения была создана первая якутская опера (либретто Д.К.Сивцева, музыка М.Н.Жиркова и Г.И.Литинского) «Нюргун Боотур Стремительный».

Жанр произведения автором не определен. Им было отмечено в начале произведения «норуот олонхотуттан» (букв. «из народного эпоса олонхо»). Однако критики определяют жанр «Туйаарыма Куо Светлолицая» как драматическую поэму (А.А. Билюкина, П.В. Максимова, Г.А. Червяченко и др.).

В драматической поэме «Туйаарыма Куо Светлолицая» П.А. Ойунский выбрал из обширного содержания олонхо «Нюргун Боотур Стремительный» лишь наиболее острые, драматически значительные эпизоды-сюжеты с богатырем абаасы Уот Усутаакы, с которым происходит напряженная и опасная схватка для героя - борьба за красавицу Туйаарыма Куо. Произведение названо именем героини, а не именем главного героя эпоса «Нюргун Боотур Стремительный». То есть в драматическую поэму переносится главная идея олонхо - идея спасения Красоты и Непорочности от посягательств племен Нижнего мира. При этом драматический конфликт двух миров полностью отражается в образе Туйаарымы Куо.

Драматическая форма произведения вырастает из структуры и исполнительской традиции олонхо. П.А.Ойунский старался сохранить композицию олонхо, открывая произведение вступлением («Аан тыла»), которое не только мотивирует представление на сцене рассказом Олонхолоона, представляющего

${ }^{62}$ Данилов С.П., Окороков Г.Г. Поэзия борьбы и созидания // Ойунский П.А. Стихотворения. - Л.: Советский писатель, 1978. - С.23.

${ }^{63}$ Билюкина А.А. Якутская советская драматургия (зарождение и развитие социалистического реализма) М.: Наука, 1988. - С. 80.

${ }_{64}$ Семенов В.А. Творчество П.А.Ойунского и становление социалистического реализма в якутской советской литературе. - Новосибирск: Наука, 1980. - С. 165. 
обобщенный образ олонхосутов, но и вводит в драматическую поэму обязательный в каждом олонхо пролог - историю «стародавних, гибельных лет». Во вступлении дается небольшое (по сравнению с олонхо) описание страны родоначальников ураангхай саха Саха Саарын Тойона и Сабыйа Баай Хотун, а также дается краткая предыстория событий.

Драматическая поэма состоит из трех действий. $\mathrm{B}$ первом действии прародители ураангхай саха собираются выдать дочь красавицу Туйаарыму Куо замуж и устраивают праздник ысыах в честь собравшихся женихов. В разгар праздника вдруг появляется богатырь абаасы Нижнего мира Уот Усутаакы и заявляет о своем намерении любым способом взять в жены красавицу Туйаарыму Куо. Если в олонхо Ойунского, Уот Усутаакы похищает Туйаарыму Куо без заблаговременного предупреждения и угроз, то в драматической поэме он во втором явлении ставит перед красавицей реальный выбор: отказаться от замужества ради собственной свободы или идти за него - Уот Усутаакы - замуж, чтобы спасти свое племя. Это злобное извещение сына абаасы заставляет дочь айыы принять решение пойти за него ради блага жизни ураангхай саха, в чем подчеркивается особый драматизм образа Туйаарымы Куо. Но в этот момент появляется Старуха Симэхсин и извещает о прибытии Юрюнг Уолана. Функциональная роль этого эпизодического персонажа - дать толчок сюжетному действию. Устами Старухи Симэхсин описывается внешний вид героя и его коня.

Таким образом, постепенное нарастание отрицательной динамики действий Уот Усутаакы, подчеркнутое в олонхо поэтапным описанием природных явлений, в драматической поэме осуществляется через образ Туйаарымы Куо. Диаметральное противопоставление айыы аймага племени абаасы происходит в первом действии, где спрессовано, в целом, содержание I-IV песен олонхо «Нюргун Боотур Стремительный». Отсюда завязкой действия в поэме служит похищение Туйаарымы Куо и Юрюнг Уолана чудовищем Уот Усутаакы. Начинается драматическая борьба людей айыы со Злом за свое счастье и мирную жизнь.

Дальнейшее развитие действия происходит в Нижнем мире (второе действие), где Юрюнг Уолан «сватается» к сестре Уот Усутаакы Кыыс Кыскыйдаан, и, используя свой острый ум и хитрость, уничтожает еe, но впоследствии погибает в неравной борьбе с богатырем абаасы. Защитник людей айыы Нюргун Боотур появляется лишь в конце второго действия.

Третье действие драматической поэмы начинается с плача Туйаарымы Куо, находящейся в заточении в жилище Уот Усутаакы, куда приходит Нюргун Боотур после тридцатидневной борьбы с чудовищем. С помощью дочери айыы Нюргун Боотур одерживает победу над врагом - это кульминационный момент 
произведения. В драматической поэме Туйаарыма Куо представлена более активной и сильной, способной принимать решения, что отличает ее от героини олонхо.

Произведение завершается оживлением Юрюнг Уолана живой водой, добытой Нюргун Боотуром, приношением жертв богине войны Илбис Кыыс и разрушением жилища абаасы. Слова Юрюнг Уолана: «Заклятье изречено, стрелою пригвождено! / Не будет горя, не будет зла!» ${ }^{65}$ [c.253] свидетельствуют о победе Добра над Злом и утверждении Жизни на земле.

Как видно, произведение «Туйаарыма Куо Светлолицая» отличается от олонхо динамикой развития сюжета. Если в олонхо события разворачиваются постепенно, то в драматической поэме отмечается динамичная смена картин.

Каждое якутское олонхо состоит из обширных описаний и больших монологов героев, их противников и всех, кто втянут в события эпоса. Они поются. В них излагается отношение героев к происходящим событиям, дается мотивировка событий, действий и т.д. Поэтическая традиция монологов олонхо в основном сохраняется П.А. Ойунским и в драматической поэме. Однако здесь монологи сильно сокращены, но сопровождаются обширными ремарками для сообщения обстановки, иногда краткой характеристики настроения присутствующих. Монологам персонажей драматической поэмы характерны такие особенности, как повторы, тавтология в описании ситуаций и событий, прямая характеристика лица, к которому обращаются. Также сохранена самохарактеристика героев, возвеличивающих себя, что собственно свойственно монологам героев олонхо.

Для иллюстрации вышесказанного рассмотрим монологи Нюргун Боотура. В четвертом явлении третьего действия «лучший из племени айыы, сильнейший из улусов солнца, царь людей саха» Нюргун Боотур приходит к красавице Туйаарыма Куо, находящейся в жилище Уот Усутаакы. Монолог героя, состоящий из 161 стихотворной строки, начинается с обращения, где дается прямая характеристика красавицы Туйаарыма Куо:

«Көр-бу!!! Көр-бу!!! Көр-бу!!! «Ну, добро! Ну добро, добро!

Көхсүттэн тэһииннээх, Милый жаворонок, ты здесь!

Көмүскэс сүрэхтээх

О твоей беде получил я весть.

Күн-өркөн улууһун

Твоя песня звенела, как серебро,

Күндү күөрэгэйэ;

Арқаһыттан тэһииннээх, Аһыныгас санаалаах В мире солнечной высоты.

Айыы хаан аймађын Синичка медногрудая ты Доброго народа айыы С поводьями за спиной,

${ }^{65}$ Перевод драматической поэмы осуществлен Вл.Державиным. Здесь и далее русский текст дается по книге: Ойунский П.А. Стихотворения. - Л.: Советский писатель, 1978. 
АраБас түөстээх

Алтан далбарайа,

Тунальаннаах ньуурдаах

Туйаарыма Куо, хотуой!...» ${ }^{66}$ [с.291]

Далее монолог Нюргун Боотура включает:

- повторное повествование произошедших событий, где излагается сюжет о том, как растили и хранили Туйаарыму Куо родители, какой красивой она стала, как начали из-за нее бороться богатыри всех трех миров;

- определение причины прихода Нюргун Боотура (получение известия о беде его младшего брата Юрюнг Уолана);

- его рассказ о своих действиях - о борьбе с Уот Усутаакы, длившейся тридцать дней и ночей;

- сообщение о способах победы над врагом, где особо подчеркивается, как должна вести себя Туйаарыма Куо в присутствии Уот Усутаакы.

Самохарактеристика главного богатыря является частью другого (заключительного) монолога Нюргун Боотура:

«...Дьулусханнаах дьолуо манан халлаан

Дьураатыгар тура төрөөбүт,

Дьулусхан субуйа сүүрүк

Дьураа хара аттаах

Дьулуруйар Ньургун Боотур диэн,

Үөһээ үөтүүлээх үрдүк-мэнийэ халлааннга

Үрдүк сурахтаммыт, үтүө ааттаммыт;

Алдьархайдаах аллараа дойдуга

Албан ааттаммыт, суон сурахтаммыт;

Буор туруу дойдуга

БуулаБатын булларбатах

Бухатыыр киһи бэрдэ...» [с.314]

Таким образом, основные функции и художественные особенности монологов персонажей олонхо в драматической поэме сохранены.

Авторские ремарки в драматической поэме выполняют несколько функций: обозначают место и время происходящих событий; дают описание внешнего вида героев, их действий; а также в них заключается описание физического и психологического состояния героев и т.д. Ремарки в произведении более подробны, стиль речи в них не столько отрывочный, лишенный художественных описаний, как в собственно драматических произведениях, сколько поэтический. Например, о появлении Нюргун Боотура читаем: «Үөһээ диэкиттэн туох да холобура суох улахан

${ }^{66}$ Здесь и далее якутский текст произведения дается по изданию: Ойунский П.А. Избранные произведения: Стихи, переводы, драматические поэмы. - Якутск: Якут. кн. изд-во, 1992. 
тыас таннары курулаан түһэр. Тобус холорук доқуһуоллаах, ақыс сата аргыстаах, суллэр этин ньиргиэрдээх, сааллар чақылБан дапсыырдаах ат атађын тыаһа үөһэ дьөлөрү-үтүгэн аартык айаБар иһиллэр. Онтон күөх уоттар таннары субуруннаан түһэллэр да - үс кырыылаах үнүү кэлэн, күөх уотунан кутааламмытынан, хорос гына түһэр. Уот Садақа мођой кутаа уотунан үнүү диэки өрө уһуутуур. Дэриэспэ таас дэлби ыстанарын курдук тыас дэлбэритэ ыстанар да - Ньургун Боотур илэ бэйэтинэн нөрүс гына түһэр. Көмүс аалыытын курдук үс хос дыгдалдыыгас куйақа күөх уотунан сырдыргыырга дылы буолар, харађа уоттанар» [с.283]. («Раздавиийся вверху ни с чем не сравнимый, оглушительный гул спускается вниз, и вслед за этим со стороны горного перевала доносится топот быстро скачущего коня, сопровождаемый сильной бурей, сверкающей молнией, громкими раскатами грома. Со стороны этого же перевала тянутся, сверкают синие языки пламени, и на середину сиены падает торчком сверкающее синим пламенем трехгранное копье. Навстречу ему Огненный Змей выдыхает пламя. Раздается сильньй треск, будто разламывается каменная скала, и копье превращается в богатыря Нюргун Боотура, одетого в сверкаюшую блеском серебряных опилок трехслойную броню. Сверкают его глаза, и как будто пьлает синим пламенем его броня») [с.212]. В тексте оригинала нами выделены идиоматические повторы, создающие ритм; поэтические сравнения, уточнения, усиливающие метафоричность представления главного богатыря айыы.

Как видно из приведенного отрывка, в ремарке довольно долго и подробно описывается появление Нюргун Боотура, что особенно ярко представлено в оригинале. Это восполняет отсутствие авторского повествования, позволяет читателю полнее представить обстоятельства, в которых протекает действие, а также внешний вид, психологический настрой богатыря.

Таким образом, композиционная структура драматической поэмы «Туйаарыма Куо Светлолицая» П.А. Ойунского особенна тем, что в ней сохранены основные композиционные приемы олонхо. Описательный компонент, обязательный в олонхо, дан здесь в виде пролога, что весьма существенно. Функции описания и повествования сказителя в драматической поэме распределены в таких сугубо драматических элементах, как ремарки и монологи нейтральных персонажей.

Систематика образов. В драматической поэме на первый план выдвигается идея создания доброй и счастливой жизни племени ураангхай саха, что воплощена в образе Туйаарымы Куо. Описание внешнего вида красавицы Туйаарымы Куо дается автором в ремарке: «ОБолоро барахсан - танас бүтэй этэ сандааран, эт бүтэй силиитэ дьалкыйан, ньуура туналыйан, сирэйэ сандааран, көрөртөн кэрэ сүөргү үчүгэй бэйэкэтэ - бар дьонугар чараас-чараастык чыпчылыйан, миигэс миигэстик мичилийэн сүгүрүс гынна» [с.242]. («Ненаглядная их дочь красива так, что сквозь платье розовеет нежное ее тело, сквозь тело костный мозг дрожит, блестит лучезарный лик ее, рдеет румяное ее лицьо, - невиданной красоть она; нежно моргая, рассматривает собравшийся народ и с задушевной ульљккой кланяется») [с.162]). 
Другие положительные герои группируются вокруг главной героини Туйаарымы Куо: родители Сабыйа Баай Хотун, Саха Саарын Тойон, старший брат богатырь Кюн Дьирибинэ, жених Юрюнг Уолан, и защитник племени богатырь Нюргун Боотур.

Родители Туйаарымы Куо Сабыйа Баай Хотун и Саха Саарын Тойон в драматической поэме показаны более реалистично. Они переживают за свою дочь, принявшей решение пойти за чудовище ради спасения племени айыы аймага. Сабыйа Баай Хотун пытается успокоить Туйаарыму Куо, уверяя, что найдется заступник-богатырь из «солнечных улусов», который поможет ей вернуться домой. И потому они искренне радуются приходу Юрюнг Уолана, приняв его за спасителя своей дочери, и всего племени. Они настолько рады и счастливы, что даже начинают подшучивать между собой.

В отличие от олонхо, в драматической поэме богатырь Кюн Дьирибинэ не борется с врагом. С Кюн Дьирибинэ мы встречаемся только в двух эпизодах - в 3 и 9 явлениях первого действия. Первый монолог богатыря Кюн Дьирибинэ вводит нас как бы в «курс дела». Он говорит о том, что больше негде спрятаться, некуда деться, остается лишь отдать красавицу за чудовище: «Знать, настал ее срок, / Знать, ей гибели день настал». Из его уст мы узнаем о подвигах Нюргун Боотура, предназначенного свыше стать защитой людей айыы:

«...Алдьархайдаах аллараа дайдыны,

Атыйахтаах уу курдук,

Аймаан тахсан баран,

Үөһээ үрдүк-мэнийэ халлаан

ҮөтүҮлээх үрүт өттүгэр тахсан,

Соқуруу соххор халлаанна

Соххор-содуомун онорбута,

Баһа-атаБа биллибэт

Балай бардамын таһаарбыта

Үс төгүрүк сыл буолла

диэбиттэригэр, -

Үс төгүл эккирэтэн көрөн бараммын,

Кини бэйэлээх уһун чүөмчүтүн,

Киэн хардыытын сиппэккэ,

Үсүһүн төннөн түспүтүм

Yhүс күнэ буолла» [c.241-242]
«...Говорят, что три года прошло с тех пор,

Как он Нижний бедственный мир,

Словно воду в ковшике берестяном,

Взболтал, расплескал,

И, поднявшись на купол небес,

Вихревых, грозовых,

Шум он поднял и гром,

Не слыханные до сих пор.

Я, помня древних заветов слова,

Трижды гнался за ним, да не мог догнать.

Конь его - у него такая юрга,

У него такой широкий намет,

Что никто не догонит его.

А вернулся я к вам лишь три дня ${ }^{67}$ назад» [c.162]

Первое действие заканчивается уходом Кюн Дьирибинэ искать Нюргун Боотура и известить его о беде племени ураангхай саха. При этом богатырь айыы твердо уверен в том, что только он сможет одолеть врага Уот Усутаакы: «Только он, Нюргун Боотур один, / Может нас защитить, / Счастье наше

\footnotetext{
${ }^{67}$ В переводе Вл. Державина последняя строка такова: «А вернулся я к вам лишь три года назад».
} 
спасти!» [с.184]. Таким образом, образ Кюн Дьирибинэ выполняет следующие функции: во-первых, в его монологе раскрывается предыстория событий; вовторых, дается характеристика Нюргун Боотура как великого богатыря, предназначенного стать защитой для племени айыы аймага; в-третьих, именно он извещает о настигшей их беде, тем самым уточняет дальнейшее развитие сюжета.

Младший брат Нюргун Боотура Юрюнг Уолан - жених Туйаарымы Куо. Мы знаем из олонхо, что Юрюнг Уолану свыше было предназначено стать родоначальником рода. В драматической поэме, как и в эпосе, Юрюнг Уолан прибывает на долину Кыладыкы с целью свататься к красавице Туйаарыме Куо. Однако все видят в нем богатыря, прибывшего защитить айыы аймага. Так, из уст самого героя мы узнаем, что богатырь Кюн Дьирибинэ считает, что «если, мол, ты придешь, / В жены возьмешь Туйаарыму Куо, / То станешь ты всем земным племенам / Покровителем и щитом» [с.170]. Или таков ответ Туйаарымы Куо: «...Как мне в сторону отойти / От защитника моего! / Ведь ради меня он сюда прилетел / С высоких белых небес, / Чтоб меня из когтей злодея спасти...» [c.174]. В драматической поэме Юрюнг Уолан показан более решительным и уверенным в своих действиях. Одно его прибытие доказывает, что Юрюнг Уолан готов принять на себя роль защитника племени. Такими словами заканчивается монолог Юрюнг Уолана, где он просит «расходиться добром по улусам своим» собравшихся со всех трех миров женихов:

«... Үс үүт бүтэйи үрдүнэн көстөр

Үрүмэччи манган аттаах

Үрүн Уолан бухатыыр диэн,

Суол-суол ахсын

Суон сурахтаммыт,

Сир-сир ахсын

Сибиэн буолан иһиллибит,

Аартык-аартык ахсын

Албан ааттаммыт киһи

Илэ бэйэбинэн, чахчы дьүһүммүнэн, Илбис энээрдэнэн, иэнигийдим курдук...»

[c.257]
«...Сам я - ездящий на белом коне, Что стоит выше изгороди столбовой, Выше трех о крепких засовах ворот.

Сам я, славный на всех дорогах земных,

В разных видах являющийся вам

Во всех пределах земных,

Я сам - богатырь Юрюнг Уолан,

В подлинном виде своем, В сопровождении духа битв, Нагрянул к вам!...»

[c.180]

П.А. Ойунский полностью сохранил эпизод олонхо, в котором Юрюнг Уолан «сватается» к Кыыс Кыскыйдаан, а потом уничтожает ее как представителя темных сил.

В образе дочери абаасы Кыыс Кыскыйдаан подчеркивается уродство, злое начало рода абаасы. Она противопоставляется образу Туйаарымы Куо. Внешний вид дочери абаасы, как и в олонхо, изображен в карикатурно- 
сатирическом плане. Описание внешности, особенности поведения Кыыс Кыскыйдаан даны в произведении с помощью ремарок.

Если образ Кыыс Кыскыйдаан служит лишь дополнением, подчеркивающим элементы уродства и злого начала рода абаасы, то образ Уот Усутаакы представляет собой собственно воплощение Зла, идею Разрушения. Отрывок из монолога одноглазого чудовища дает понять об его страшном намерении - уничтожить не только одно племя, но и священное обиталище людей - Средний мир: «...Я своими ногами железными, сам, / Раскачаю, с места спихну / Восьмигранную, о восьми ободах / Изначальную землю-мать! / Словно воду в берестяном ковше, / Взболтаю, взмучу, расплещу / Всю зеленую вашу страну.../ В море выплесну девятимысный ваш край, / Словно воду из берестяного ковша! / Каждое жилище у вас / Черныл дылом наполню я. / Всех мелькающих, словно тени, людей / Я на вашей земле изведу. / Всех бродящих, словно призраки, ваших людей / Уничтожу, выморю навсегда! / Я ваш дом огнем истреблю, / И от вашего золотого гнезда / Не останется ни следа. / Я, играя, разрушу ваш очаг, / Я развею пепел его. / Я вас всех растопчу, / Смеясь, хохоча... / Ха-ха-ха! / Хо-хо-хо!» [c.159].

Богатырю абаасы Уот Усутаакы, его идее разрушения и уничтожения противопоставляется образ защитника племени Нюргун Боотура, в котором заключается идея защиты Добра и счастливой жизни ураангхай саха. Хотя в произведении Нюргун Боотур появляется лишь в конце второго действия, о существовании великого богатыря мы узнаем еще в первом действии в диалогах и монологах других персонажей. Эпизодический персонаж Кюн Дьирибинэ введен автором в драматическую поэму специально для раскрытия образа Нюргун Боотура. Высшее предназначение Нюргун Боотура как защитника племени ураангхай саха также каждый раз повторяется Юрюнг Уоланом в его монологах. Следовательно, образ Нюргун Боотура как защитника идеи Добра и Счастья существует в сердцах и мыслях каждого персонажа, и мечты о нем проходят через все события произведения. Драматический конфликт между Нюргун Боотуром и Уот Усутаакы, отражающий философскую идею о борьбе за утверждение в Среднем мире жизни и красоты, разрешается в пользу защитника племени. Спасением красавицы Туйаарымы Куо Нюргун Боотур утверждает Добро и Счастье на земле ураангхай саха.

Таким образом, сюжет драматической поэмы «Туйаарыма Куо Светлолицая», в целом основан на одной из сюжетных линий олонхо «Нюргун Боотур Стремительный», а именно, на развитии образов Туйаарымы Куо и Юрюнг Уолана. При этом сохраняется главная идея олонхо, идущая от основного конфликта эпоса - противостояния Среднего и Нижнего миров. Спрессованный сюжет эпического сказания сообщает действию драматической поэмы особую динамичность. В композиционном плане это наблюдается в усилении значения вспомогательных персонажей, монологи которых 
раскрывают описательные части олонхо, например, портретные характеристики героев. Особую функцию выполняют ремарки, равные авторским отступлениям в развитии конфликта и тем самым усиливающие поэмное начало.

Драматические поэмы «Туйаарыма Куо Светлолицая» и «Красный Шаман» П.А. Ойунского вправе называться в истории якутской литературы первыми опытами в этом жанре. Влияние поэтики олонхо заключено в них, прежде всего, в отражении философской идеи якутского эпоса о борьбе за утверждение в Среднем мире красоты - символа благополучия племени айыы аймага, а также в особенностях композиционного строения произведений, в характеристике главных героев.

Противопоставление идей, отражающих народное миропонимание, и глубокое поэмное начало, заключенное в художественной необходимости «присутствия» автора, делают данные произведения поистине высокими образцами якутской словесности. Они по образным параметрам соответствуют именно драматической поэме, которая по своей жанровой данности выступает тем произведением, где национальное (форма, проблематика, система образов) и общечеловеческое (тема, идея) органически соединяются в художественной идее, образах и символических иносказаниях поэтической речи.

\section{Контрольные вопросы и задания}

1. Сделайте сопоставительный анализ образа Туйаарыма Куо в драматической поэме и в олонхо П.А. Ойунского.

2. Имеют ли ремарки значение в определении опорных точек композиции?

3. Какова композиция сюжета драматической поэмы «Туйаарыма Куо Светлолицая» на микро- и макроуровне?

4. Докажите определение «Туйаарыма Куо Светлолицая» - драматическая поэма на фольклорной основе”.

\section{Упражнения и задания для СРС}

1. Определите на примерах из текста драматической поэмы «Туйаарыма Куо Светлолицая» расширение функции вспомогательных персонажей олонхо.

2. Проведите сопоставительный анализ образов богатырей (Нюргун Боотура и Юрюнг Уолана) олонхо П.А. Ойунского «Нюргун Боотур Стремительный» и драматической поэмы «Туйаарыма Куо Светлолицая».

3. Проанализируйте стиль речи в ремарках «Туйаарыма Куо Светлолицая». Восполняют ли ремарки отсутствие речи сказителя-олонхосута в драматической поэме.

\section{Литература}

1. Григорьева Л.П. От олонхо к драматической поэме // П.А.Ойунский: мифы и реальность / АН РС(Я), ИГИ; отв. ред. В.Н.Иванов и др. - Якутск, 2004. - С. 92-101. 
2. Дмитриев П.Н., Ойунская С.П. П.А.Ойуунускай уонна олонхо // Ойунский П.А. Нюргун Боотур Стремительный: Олонхо / второе, полное издание. Подготовка к печати П.Н. Дмитриева, С.П. Ойунской. - Якутск, 2003. - С. 519 - 542.

3. П.А. Ойунский: Взгляд через годы. - Новосибирск: НИЦ ОИГГМ, 1998.

4. Семенов В.А. Творчество П.А. Ойунского и становление социалистического реализма в якутской советской литературе. - М.: Наука, 1980. - 220 с.

5. Семенов В.А. Фольклорные сюжеты и мотивы в творчестве П.А. Ойунского. Якутск: Якут. кн. изд-во, 1966. - 76 с. 


\section{IV гЛава. КОМПОЗИЦИОННЫЙ АНАЛИЗ ДРАМАТИЧЕСКИХ ПОЭМ}

\section{1. Поэма Таллан Бюрэ «Уолан Эрилик»}

Особенности композиционной структуры. Поэму Таллан Бюрэ «Уолан Эрилик» (1943) с жанром драматической поэмы сближает, прежде всего, ее драматизированная форма (идеи главных персонажей передаются с помощью диалогов и монологов); в поэме на первый план выводится героическая личность, находящаяся в трагической ситуации. Однако в ней присутствуют углубляющие лироэпическое (поэмное) начало различного рода описания, авторские отступления.

Над поэмой «Уолан Эрилик» Таллан Бюрэ работал на протяжении многих лет: автор начал свое произведение, когда ему было 27-28 лет, и окончательно завершил в 60 лет. Поэма впервые увидела свет в 1944 г., а второе переработанное издание вышло в 1963 г. Полный текст «Уолан Эрилик» вышел лишь в 1971 г.

Поэма состоит из восьми песен и эпилога. В начале произведения имеется посвящение, датированное 1937 г. Главными противоборствующими сторонами в произведении выступают Уолан Эрилик и Тойон Дуолан, которые в детстве были друзьями. В первом эпизоде первой части дается предыстория событий (экспозиция): автор описывает место происшествий, знакомит с героями поэмы, описывает внешний вид, социальное положение, образ жизни каждого персонажа. Завязкой конфликта произведения выступает похищение Тойон Дуоланом прекрасной Айталы Куо: в неравной борьбе Уолан Эрилик теряет свою возлюбленную. Мысль о личной мести Уолан Эрилика постепенно приобретает иное качество - он становится борцом за свободу всего народа. Во второй песне Уолан Эрилик получает известие от возлюбленной о том, что Тойон Дуолан держит ее взаперти, и что она ждет его. Это дает ему надежду. Здесь автор сталкивает Уолан Эрилика в диалоге с Тойон Дуоланом, где последний просит пощадить его и клянется вернуть Айталы Куо в родной дом. О том, что Тойон Дуолан нарушил клятву, мы узнаем, когда верные друзья Уолан Эрилика приводят Русского воина, смертельно раненого Тойон Дуоланом, и говорят: «Саха, саргын самынна / Биһи кириэппэспит умайда» ${ }^{68}$ [c.309] («Саха, твоя мечта разрушена / Наша крепость сгорела» ${ }^{69}$ ). В монологе Русского воина значителен его рассказ о страданиях Айталы Куо, находящейся

${ }^{68}$ Здесь и далее текст поэмы дается по изданию: Таллан Бюрэ. Скалы реки Лены: стихи, поэмы. - Якутск, 1971.

69 Здесь и далее подстрочный перевод на русский язык наш - Л.Г. 
в заточении у Тойон Дуолана: он ее увидел и даже признался ей в своих чувствах. Однако в глазах прекрасной девушки он увидел большую любовь к другому: «Эйигин нарын кыыс санааргыыр / Харана харађар көрөрүм. / Ахтар Айталы уоһугар / Аатын эйиэнин истэрим. / Өлүүм-сүтүүм бу суоһугар / Эйигин үөрэ ... көрсөбүн» [c.310] («В темных глазах девушки милой / Тебя я видел. / В устах скучающей Айтальь / Имя твое я сльшиал. / Перед смертью встретил тебя / Рад я этой встрече»). Русский воин дарит Уолану свой меч:

«Ыл. Өлөрсөн өнө суһуйда,

Охсуһууларга уйадыйда.

Үс ууһум Русь туһа диэн

Үстэ андаБар эппитэ,

Үс төгүл кыргыһаaры туран

Үстэ күлүгэр үнпүтэ.

Саарабыл кэмигэр, оо, сэгээр,

Санаалаах самныын күнүн

Төлөннөөх охсуһуун түбүгэр

Санааргыы киниэхэ үнээр

Онно киниэхэ имэн түһүө,

Көлдьүн күлүмэр тыгыа

ӨстөөБүн уодаһынын, Доқорун итэБэлин» [c.313]
Возьми. В битвах

Цвет его потускнел.

За Великую Русь

Клятву дал он трижды,

Перед битвой трижды

Молился тени его великой.

В моменты отчаяния, о, дорогой,

В день краха мечты своей

В разгаре борьбы с врагом

Ты молись ему

Вот тогда ему сила и страсть вернутся,

И ты увидишь

Жестокость врага,

Веру друга.

В конце этой песни Уолан Эрилик дает клятву, что он не отступится от борьбы за справедливость. В третьей песне повествуется о празднике ысыах, устроенном в честь Айталы Куо. Здесь дается довольно обширное описание места проведения и времени ысыаха. В повествовании о самом празднике описываются прием гостей, питье кумыса, национальные игры (перетягивание палки, прыжки в длину), исполнения песен, осуохай, олонхо. Торжество прерывается приходом Уолан Эрилика и его воинов. В монологе героя, обращенном к Тойон Дуолану и его окружающим, указывается причина его борьбы: «Эн болотун дьулаанынан, / Албан аатын абынан, / Аадын, араайын аатынан / Албыннын-сааккын сабынан, / Үрүн саардыын эһи кыайдыгыт, / Дьаһаађы ылар буоллугут» [с.319] («Своим мечом грозным, / Своим именем великим, / Своим раем и адом, / Покрывая обман и стыд, / Победили вы вместе с Царем / Вы стали собирать ясак»). Как видно из слов Уолан Эрилика, личная месть отодвигается на задний план, на первое место выводится идея борьбы за свободу. Автором не описывается, как сражаются воины, им подчеркивается итог этой борьбы: родная земля - прекрасная долина Туймаада - уничтожена, все сгорело. Увидев содеянное им Зло, Уолан Эрилик презирает себя: он покидает родную землю. Его монолог, посвященный дереву Аал дууп, полон 
обиды и отчаяния. Перед уходом Уолан Эрилик вешает свое окровавленное оружие на дерево. В четвертой песне поэмы Уолан Эрилик помогает жене и сыну Тойон Дуолана спастись от беды. О встрече Уолан Эрилика и Айталы Куо повествуется в пятой песне, сцена их встречи очень трагична. В предсмертном монологе героини раскрывается ее глубокое сожаление о своей короткой жизни, ее несбывшаяся мечта о свободе, которую ощущала только во сне. Смертью Айталы Куо поэма достигает своей кульминации. В шестой песне действие поэмы переносится на Север. Уолан Эрилик просит у Северного моря благосклонного отношения к нему и приносит ему в жертву своего противника. В седьмой песне мы узнаем о том, как Уолан Эрилик стал пленником тунгусского племени, вождем которого является Айала - отец его близкого друга Дьэргилэ. В последней восьмой песне Айала, рискуя своим благосостоянием, отпускает Уолан Эрилика на свободу. Герой постепенно начинает вспоминать о своих былых подвигах, и у него с новой силой возгорает стремление к борьбе. Уолан призывает людей Айала поехать с ним в его многострадальную землю, охваченную борьбой за свободу. Этого и боялся вождь северного племени. В конце восьмой песни воины прощаются с Великой Рекой (Улуу БайБал). Как отмечает П. Ильин, автор большой статьи по идейнотематическому анализу поэмы Таллан Бюрэ, здесь поэт описывает уход якутян на Великую Отечественную войну ${ }^{70}$ В последнем монологе Уолан Эрилик говорит о своей мечте - быть всегда и везде свободным, как эта Великая Река. Однако в эпилоге Уолан Эрилик, утратив былую воинскую славу, превращается в каменную скалу без названия:

«...Уонна Дьыльа кинини кыраабыт

Буруйун-айыытын иэһигэр,

Будулуйар долгунум үөһүгэр

Киһи ... очуос буолан хаалбыт.

Дьыльа ол киһиэхэ эппиттээх:

Эн тылгынан икки атахтаах

КэнэБэс эйигин билбэтин диэн,

Кэнэн ааттаргын эппэтин диэн... [с.347]
И Судьба его прокляла

За содеянные грехи, Над волнами

Человек ... превратился в скалу.

Судьба этому человеку сказала:

Твоими словами двуногий

Пусть не знает о тебе в будущем,

Пусть не произносит имя твое.

В конце произведения говорится, что действительно есть такая гора на Лене и стоит она «одиноко скучая, как забытый титан, без имени и славы».

Завязкой действия поэмы выступает похищение Айталы Куо, а в дальнейшем развитии сюжетного действия наблюдается переход личных стремлений героя к Любви и Красоте в осуществление цели определенного

\footnotetext{
${ }^{70}$ Ильин П. «Уолан Эрилик» ис дьинээ // Чолбон. - 1994.- № 6. - С. 200.
} 
социального общества - угнетенных. И эта вторая цель становится истоком идеи борьбы Уолан Эрилика за свободу и справедливость. Но победа над Тойон Дуоланом и его воинами не приносит ему удовлетворения: Уолан Эрилик приходит к мысли, что борьба приводит только к беде и в подтверждение своего отказа от нее оставляет оружие на дереве Аал дууп. Наступает скрытая развязка конфликта произведения. Однако кульминационным моментом в поэме выступает смерть невинной девушки Айталы Куо, явившейся причиной борьбы героя (пятая песня). На наш взгляд, предсмертный монолог Айталы Куо должен предшествовать эпизоду из третьей песни, где герой убеждается в неправоте своих деяний и, демонстрируя свой отказ от борьбы, вешает оружие на дереве. В таком композиционном решении развязка конфликта между Уолан Эриликом и Тойон Дуоланом получилась бы более убедительной.

Последующие песни поэмы повествуют о дальнейшей судьбе героя, где конфликт переносится во внутренний мир Уолан Эрилика. Образ главного героя приобретает несколько иной оттенок, чем в первых пяти песнях. Из реального борца за свободу он как бы превращается в символический образ, представляющий собой идею борьбы. Известно, что эти последние три песни и эпилог автор написал в 1941-1944 гг.

В системе образов особое место отводится Уолан Эрилику, все события поэмы связаны с его действиями. Другие персонажи поэмы выполняют определенные функции, зависящие от проблематики эпизодов действий главного героя. По мере выполнения своей функции они выбывают из сюжета.

Главный герой поэмы Уолан Эрилик - сын бедных людей. В роду у него имелся особенный человек - прорицатель, философ от природы: «Уолан Эрилик ону утумнаан: / Дьулуура - үрдүк, модун - санаата, / Бар дьон үтүө көнүлүн илиннээн, / Олобун охсуһууга анаата» [c. 296] («От него перенял Уолан Эрилик: / Отвагу - высокую, мыссль - великую, / За борьбу ради свободь всех людей / Жизнь свою он отдал»). Мысль о личной мести за любовь к Айталы Куо превращает Уолан Эрилика в вождя всего народа в борьбе за свободу. К нему соединились те, кто пожелал стать свободным («Ким алаһа дьиэтиттэн барбыт .../ Ким дьаһаађы, сокуону утарбыт» («Кто из дому ушел, кто пошел против закона, ясака»)). Окружают героя люди разных национальностей, автор называет их «людьми свободы» («Көнүл уолаттара»). Здесь мы встречаемся с Дьэргилэ, сыном тунгусского племени, якутом Дохсун Догусуол и Русским воином. Особая роль отводится образу Русского воина, который был смертельно ранен Тойон Дуоланом. Русский воин, очарованный красотой девушки Айталы Куо, полюбил ее с первого взгляда, о чем мы узнаем из его монолога. Меч, подаренный Русским воином Уолан Эрилику в знак любви к 
Айталы Куо и дружбы к нему, - символ борьбы. Этим Русский воин благословляет героя к борьбе. Уолан Эрилик клянется, что не изменит своего решения, будет бороться до последнего: «из нас двоих пусть один умрет, из нас двоих пусть один победит». Однако победа над своим врагом не принесла ему желаемых результатов: стерта с лица земли его родина, погибла любимая женщина, он убедился в неправоте своих действий. Для иллюстрации трагедии героя приведем его прощальный монолог, посвященный родной земле Туймааде, где слышен голос отчаяния и разочарования:

«Бырастыы нии, уонна эн биһи

Аны көрсүһүөхпүт суоқа.

Мин бардабым, дьоло суох киһи,

Мин ааппын бар дьон умнуођа,

Оттон эн ордук дьону булуон,

Кинини дьолгор оонньотуон,

Эппэтэх эйэ тылгын этиэн,

Албан ааккынан киэргэтиэн!

Оттон миигин эн сээн диэбэтин

Биирдэ бу кылгас үйэбэр,

Миэхэ биирдэ өйөбүл буолбатын

Үөрэр да, ытыыр да күммэр...

Бырастыы, ыраах-ыраах бардым

Мин биллибэт ол дойдуга:

Мин хоргута, мин ытыы бардым,

Мин - бараммыт биис ордуга».

[c.324]
Прости, прошу, и мы с тобой

Не увидимся никогда.

Я, несчастный, ухожу,

Имя мое забудет весь народ,

А ты найдешь лучших людей,

Их ты счастьем одаришь,

Невысказанные слова мира ты

скажешь,

Великим именем своим их прославишь!

А меня ты добрым словом не одобрила

Хотя бы раз в моей короткой жизни,

Не стала мне поддержкой

Ни в радостные, ни в горькие дни мои...

Прощай, ухожу далеко-далеко

В незнакомую мне страну:

Я ухожу горе свое оплакивать,

Я - частица истребленного племени.

Герой хочет забыть свое имя, которым раньше гордился. В диалоге с Үчүгэй Өрүүһэ (Прекрасной Аришей) Уолан Эрилик говорит:

«Аат! кими кэрэхсэтиэн...

Син биир хардата суох сүтэр

Түһэр сулуһум төлөнүнүҮ,

Түүннү муммут кылаһыныы

Кини дорђоонугар суох үөрүу -

Кэнэн аналынан кини баай;

Киниэхэ баар үтүөнү үөБүу,

Кэрэни холуннарыы киниэхэ баар».

[c.329]
Имя! кого интересует...

Все равно угасает без ответа,

Как искорка падающей звезды,

Нет радости в звуках его,

Как у заблудшего ночью крика -

Оно богато участью несчастной;

Есть у него укор всему хорошему,

Есть у него порицание прекрасному.

Таким образом, крах мечты о свободе, о любви приводит героя поэмы к большой личной трагедии, что подчеркивается в его монологах. Автор уводит своего героя подальше от земли, где умерла его идея. В далекой северной стране Уолан Эрилик ищет уединения, успокоения. Как мы отметили выше, 
здесь образ героя приобретает символический характер: теперь в нем автор воплощает собственно идею борьбы.

Уолан Эрилик находится в плену у вождя тунгусского племени старца Айала, который, узнав о дружбе героя с его сыном Дьэргилэ, относится к нему доброжелательно. Однако он боится отпускать Уолан Эрилика на свободу, объясняя это тем, что он может принести большую беду в мирную жизнь племени. Мы узнаем, что Уолан Эриликом интересуются и люди соседних племен; они предлагают за него старцу Айале много богатства и добра. Но вождь племени отказывается выполнить их просьбу. Он говорит, что Уолан Эрилик - знак вымершей идеи («...Кини ... сууллубут сурт бэлиэтэ, / Кини өспүт өтөх өһүөтэ...» [c. 342]). В этих песнях автор называет своего героя не по имени, а просто «Пленный» («Кэлгиэлээх киһи»), и говорит о нем в прошедшем времени. О себе Уолан Эрилик также говорит в прошедшем времени:

«Былыр, дьон көнүлүн көрдөһөн Баайы, саары утарыыта, Өлүү, өһүмньү утабынан Өлөрсе тиһэх киириитэ, Бадақа ... инники кэккэБэ Мин эмиэ иһэр этим, Эрдэ туран, иһэр үйэรэ Эрдэ иэспин биэрбитим...» [c.339-340]

В прошлом, когда люди за свободу свою Встали против богатых и царя, В бою последнем В днях смертельных боевых Кажется... впереди И я шел тогда, Встав рано, грядущему веку Отдал я рано долг свой...

Эти слова героя, на наш взгляд, направлены на осмысление того, почему борьба героя лично для него потерпела неудачу: он встал на борьбу за свободу народа, верил в идеалы этой борьбы, но настало время, когда народ в него самого не поверил.

Противоборствующую Уолан Эрилику сторону представляет образ Тойон Дуолана - сына богача Туймаады Арылыас, известного даже самому Царю Российскому. Тойон Дуолан имеет все: богатство, высокий чин и большое счастье. Однако у него не было совести и долга перед Родиной. У Тойон Дуолана уже имеется жена по имени Прекрасная Ариша (Үчүгэй Өрүүһэ) и сын. Подобно богатырю абаасы из олонхо, Тойон Дуолан похищает Айталы Куо, тем самым завязывается конфликт произведения. Власть и сила Тойона Дуолана описываются в третьей песне, где устраивается ысыах в честь Айталы Куо. Его величие и сила также подчеркивается данным автором именем Тойон Дуолан, где «тойон» - богач, «дуолан» - имеющий большую силу, могучий ${ }^{71}$. О Тойон Дуолане повествуется в трех первых песнях.

\footnotetext{
${ }^{71}$ Краткий толковый словарь якутского языка / Под ред. П.С.Афанасьева. - Якутск, 1994. - С.57, 190.
} 
Айталы Куо, дочь бедной женщины Саргылааны, является причиной вражды между Уолан Эриликом и Тойон Дуоланом. Описанию внешнего вида своей героини автор уделяет особое внимание. Она прекрасна, подобно эпическим красавицам:

«Кыыһа - үрүн дьиэ үрүмэччитэ, Хара дьиэ хараначчыта,

ТэннээБэ эрэ кыталык көтөр,

Кыыс дьахтар оһуобайа,

СанааБа биитэр түүлгэ көстөр

Сахаттан кыраһыабайа.

Ол кыыс - эдэр дьон сырдык бақата,

Кырдьақас ааспат абата,

Ол иһин үс сахам таптаабыт,

Айталы Куо диэн ааттаабыт».
Дочь ее - белого дома бабочка,

Черного дома ласточка,

Сравнится с ней только птица стерх,

Девушка особая она,

Красавица из саха, которую

Увидеть лишь можно во сне, да в мечте.

Та девушка - светлая мечта людей молодых, Непреходящая обида людей старых, Потому полюбил ее весь народ саха И назвал именем Айталы Куо.

Кроме Айталы Куо, в поэме есть еще другой женский образ - образ Прекрасной Ариши, жены Тойон Дуолана. Она становится подругой Айталы Куо: разделяет ее горе. С ее помощью встреча Тойона Дуолана с Айталы Куо каждый раз переносится на другой день. Однако, как становится известно потом, именно от ее рук погибает Айталы Куо. Автор умалчивает о причинах этого поступка. Может быть, она убила Айталы Куо, обвинив ее во всех своих бедах - гибели мужа, потери богатства и всех жизненных благ. Поступок героини П. Ильин трактует следующим образом: «Для противоборствующих сторон Айталы Куо явилась причиной борьбы, большого греха. Прекрасная Ариша убивает Айталы Куо, чтобы спасти сына, т.е. продолжателя рода айыы аймага; убивая ее, Прекрасная Ариша уничтожает символ борьбы (кыргыс)» ${ }^{72}$.

Как видно, взаимоотношения между героями поэмы сложные: Уолан Эрилик борется и побеждает Тойон Дуолана, Прекрасная Ариша убивает Айталы Куо, Уолан Эрилик спасает Прекрасную Аришу и ее сына, старец Айала отпускает на свободу Уолан Эрилика, а тот призывает его людей на борьбу.

В поэме много описательных и повествовательных частей. Почти каждая песня поэмы завершается лирическим отступлением, в ходе развития действия так же наблюдаются авторские вторжения в виде лирических отступлений, обращенных читателю или героям поэмы. Например, таковы обращения автора к читателю:

«Хомус этигэн диэн дьон тылын, Поздний читатель мой, знал ли, Хойукку ааБааччы, билэриэн? Что говорили люди о хомусе?

\footnotetext{
${ }^{72}$ Ильин П. Указ. статья. - С. 195 (перевод на русский язык наш - Л.Г.)
} 
Хомуһум туойар тойугун

Долгуйа ханна истэриэн?» [с.300]

«Ат сылгы киһилии ытыырын, АаБааччы, көрөр буоларыан? Арахсыһap күнүн кырыырын АБам дьоннортон истэриэн?» [с.327]
Звуки и песню хомуса

Волнуясь, слышал ли ты где?

Видел ли ты когда-нибудь, читатель, Как конь плакал, словно человек? Слышал ли ты у людей старших о том, Как он день разлуки проклинал?

Чаще всего автор обращается к своему герою - Уолан Эрилику: «Ол да буоллар, тиэтэй эрэ, Уолан! ...Все равно, спеши, Уолан! Күн ааһыа - үйэни сүтэриэн...» День пройдет - век потеряешь...

«...Манна суостаах иирээн демона Суланыан, сонньуйуон дуу? Сэмэ-сунха сэргэх Уолана, Сэмэлэнэ саныан дуу?» [с.330-331]

«Уолан! Кимин хаалла кэннигэр? Дођотторун мэлийдилэр, Сир оболоро сир иннигэр СирдээБи иэстэрин биэрдилэр.

Оттон эн, анардас Уолан, Хайа суолунан барыаххыный? Хаһан, ханна ким-туох буолан Эн биһи көрсүһүөхпүтүй?» [с.335]

Здесь, демон страшной борьбы, Проклянёшь ли себя ты?

Уолан, знавший о расплате за грехи свои, Будешь ли ты себя винить, презирать?

Уолан! Кто остался у тебя?

Друзей своих потерял, Дети земли за землю Земной отдали долг.

А ты, одинокий Уолан, По какой дороге пойдешь? Когда, где, как мы с тобой Встретимся вновь?

Как видно из вышеизложенного, в композиционной структуре и развитии сюжетного действия поэмы в целом наблюдается рецептивный дискурс эпической идеи олонхо. Так, в поэме имеется экспозиция, где дается описание места событий, повествование о происхождении и жизни главных героев (первый эпизод первого действия). Завязкой конфликта произведения, как и в олонхо, служит похищение красавицы Айталы Куо Тойоном Дуоланом. Идея борьбы главного героя за свободу всего народа также перекликается с художественной концепцией олонхо. Кроме этого, в поэме весьма значительна смысловая функция дерева Аал дууп.

В именах главных персонажей также наблюдаем заимствования из фольклора: Уолан Эрилик - Юрюнг Уолан, Айталы Куо - Айталыын Куо. Описания быта, жизни отдельных героев (Арылыас Баай, Тойон Дуолан, Айала) сделаны в гиперболическом стиле олонхо. Вместе с тем, в поэме «Уолан Эрилик» авторское внимание, главным образом, сосредотачивается на одном герое, которым является Уолан Эрилик. Сталкивая своего героя в борьбе против 
богатства, гнета и с другими жизненными явлениями, автор прослеживает динамику этого образа в социально-историческом ракурсе. Например, борьба героя против байского гнета, царского ясака и других несправедливых законов относится к дореволюционному времени в жизни народа. Период жизни героя, где он уходит на Север и находится в плену у тунгусского племени (три года) характеризуется как переломный момент: он переживает большую личную трагедию, с одной стороны, а с другой - ждет созревания народного самосознания для борьбы за свободу. В этом плане герой поэмы может восприниматься как предвестник революции.

Вместе с тем, нужно отметить, что если особенности композиции и систематики образов драматических поэм П.А. Ойунского обуславливаются их прямой генетической связью с олонхо, то в поэме Таллан Бюрэ они вызваны, прежде всего, стремлением раскрыть сложное содержание, а именно судьбу героической личности в контексте социально-исторических явлений.

\section{Контрольные вопросы и задания}

1. Какие исторические события отражены в поэме Таллан Бюрэ «Уолан Эрилик»?

2. Какова роль фольклорных средств выразительности в поэме? Определите ее на уровне поэтического языка и особенностей стиха.

3. Определите значение последних частей поэмы (VI, VII, VIII песни) в раскрытии идеи Уолан Эрилика.

4. Определите тему, идею и проблематику произведения на основе анализа монологов Уолан Эрилика и лирических отступлений.

\section{Упражнения и задания для СРС}

1. Изучите историю создания поэмы Таллан Бюрэ «Уолан Эрилик». Сделайте сравнительно-сопоставительный анализ изданий 1944, 1963, 1971 гг. на уровне композиции.

2. Прочитайте поэтическое произведение И. Чагылгана «Нюргустай Куо».

3. Проведите сравнительно-сопоставительный анализ произведений Таллан Бюрэ «Уолан Эрилик» и И. Чагылгана «Нюргустай Куо».

3. Определите влияние поэтики олонхо в этих поэмах в ракурсе композиции, системы образов и раскрытия функций внесюжетных элементов.

4. Сравните образы главных героев. Проанализируйте речь героев, определите особенности каждого.

5. Определите жанровую форму произведений. Назовите характерные особенности драматической поэмы.

\section{Литература}

1. Ильин П. «Уолан Эрилик» ис дьинэ// Чолбон. - 1994.- № 6. - С. 185-211

2. Бурцев Д.Т. Якутский эпос олонхо как жанр.- Новосибирск: Наука, 1998. - 85 с.

3. Максимова П.В. Якутская поэма. История и типология жанра. - Якутск: Изд-во Якутского ун-та, 1993. - 150 с. 
4. Покатилова Н.В. К вопросу о сюжетной структуре эпического жанра олонхо // Устный эпос: Проблемы истории, теории и сказительства. - Якутск, 1994. - С. 13-15

\section{2. Функции авторских ремарок в поэме М. Тимофеева «Возвращение»}

Поэма «Эргиллии» («Возвращение», 1986) М. Тимофеева повествует о судьбе исключительной личности. Автор определил жанр своего произведения как «поэму-тойук» (поэма-песнь). Поэма раскрывает тему войны. В основу образа Саргы Сахадовой положены реальные события из жизни первой якутской женщины-летчика Веры Кирилловны Захаровой, участницы Великой Отечественной войны. Помимо песен главной героини в поэме слышен голос Земли (Сир сангата), в котором воплощен поэтический образ Родины-Матери. Несмотря на небольшой объем, поэма разбита на отдельные части (пролог, три части (төгүлэ) и эпилог).

Из вступления мы узнаем о том, что Саргы Сахадова вернулась на родину спустя двадцать пять лет со дня окончания войны: она просит прощения за свое долгое отсутствие. В песне-монологе выражается любовь героини к родной земле, большая радость от встречи с ней; она приветствует родину, своих земляков. И слышатся ей слова родной природы:

«Саргы, Саргы Сахадова, Саргы, Саргы Сахадова,

Сэрии тыына, силлиэ-буурђа

Астыбыта

Сүүрбэ бэһис, сүүрбэ бэһис сыла ааста.

Тоэо, тољо бачча уһаан,

Тобо, тобо бачча уһаан,

КүҮтэн-күҮтэн баран, күүппэт

Буолбут кэннэ,

Кэлин тиһэх Ийэ сиргэр

Эргилиннин?»

Эта строфа повторяется в конце первого и второго частей поэмы.

Первая часть поэмы посвящена воспоминаниям Саргы Сахадовой о детстве и юности. Свою радость героиня выражает через песни: красота природы родной земли воспевается в песне девушки («Ынах хомуйар кыыс

${ }^{73}$ Текст поэмы дается по изданию: Тимофеев М. (Эргиллии) Возвращение: поэма // Чолбон. 1990. - № 4.- С. 53-58. Здесь и далее подстрочный перевод на русский язык наш - Л.Г. 
ырыата»), воспоминания о национальном празднике ысыах передаются через осуохай, а всенародно любимая песня «Көлүкэчээн» напоминает ей родной алас. Каждая песня в отдельности состоит из 18-32 стихотворных строк. Первую часть поэмы от двух других частей отличает то, что в ней много ремарок, которые не столько сообщают место и время происходящих событий, сколько являются повествовательной частью поэмы. Если, например, взять вместе все ремарки первой части, то складывается цельная картина жизни в ее развитии.

«Саха алааһа. Сайылык тэлгэһэтин сиэдэрэй дьүһүлгэнэ. От-мас көђөрөн, сайын мунутуу чэлгийэн турар кэмэ.

Саргы Сахадова. «Оо, ођо саас!.. Күһэлтэни көрбөтөх көнүл саас! Мин сааһырдым... арааһа, ол онтон буолуо, - мин мэлдьитин саныыр буоллум атах сыгынньах ынах хомуйа сүүрэр кэммин. Төһөлөөх элбэхтик түүн түһээн көрбүтүм буолуой бу - төрөөбүт алааспын...». Туора түһэн сытар дүлүн маска кэлэн олорор. Турар, эргийэ хаамыталыыр, дьиэрэнкэйдээн үнкүүлээн ылар, ыллыьыр... Бллыыр ынах хомуйар кыыс ырыатын»

(Якутский алас. Сайыльк. Кругом все позеленело, лето в самом разгаре. Cаргы Сахадова. «Оо, детство!.. Беззаботная прекрасная пора!.. Видно оттого, что время уходит, я часто вспоминаю те года, когда босиком бегала за коровами. Вы не представляете, как много раз мне снился мой родной алас». Подходит и садится на дереве, лежащем на земле. Встает, ходит по кругу, подтанциовывает «дьиэрэнкэй», поет... Поет песню девушки, идущей за коровами).

«Кыстык күөлтэн сайылык алааска көһөн кэлии!.. Онтон окко киириэх иннинэ маннык үрдүк күннээх, күөх чэчир ырааһыйа түһүлгэђэ түмсэн ыһыах ыhыы!!. Оһуокай!. Оо, оһуокай умсульаннаах ырыа дуораана, лаглайа тэбэр нађыл-наскыл хаамыыта, киһи эрэ көтөђүллэр күөгэл-күлүмэх көтүүтэ!.. O, үчүгэй да кэм ааспыт» (Переезд с зимника в сайылылк!... Перед уходом на сенокос в такой прекраснылй яркий летний день собраться в тюсюлгэ и праздновать ысылых!.. Осуохай!. Оо, осуохай, ты соединяешь в себе и пение, и танец, даруюшие людям энергию и радость! О, какое прекрасное время проило).

«Үөһэ тыынар. Кэлэн дүлүн маска эргийэ хааман олорор. Чочумча чуумпуран, чөрбөйөн чыычаах ырыатын, сиккиэр тыаһын иһиллээн ылар. Кини иһиттэБинэ хатын чаран, ойуур быыһыттан ырыа дуораана кэлэр. Кини эмиэ сыыйа ыллаан киирэн барар» (Вздыхает. Подходит и садится на бревно. В какое-то время сидит тихо, прислушивается к пениям птиц, дуновению 
ветра. Ей кажется, что со стороны березовой рощии сльшна песня. Она тоже начинает петь).

«Мин ити ырыаны - «Көлүкэчээни» иһиттэхпинэ - төрөөбүт алааһым ойбон көлүкэтин саныыбын. Ол - кыһыны быһа ынахтарбын, торбосторбун үүрэн киллэрэн уулаппыт көлүкэм, саас мууһа бардађына, кэрэчээн да буолара. Маннай кэлбит сааскы лоокууту, чөкчөнөнү, үрүн тыыраахы үөрдэрин көрө охсоору - уу баһар туос ыақастарбын, оргуһахпын туппутунан, эниэни таннары сүүрэн түһэрим...» (Когда я сльшу эту песню «Көлүкэчээн», то вспоминаю озерко родного аласа. Это озерко, куда зимой я водила поить своих коров, телят, весной становилось очень красивым. Я всегда спешила посмотреть на стаю только что прилетевших куликов, бельх чаек: держа в руках берестяные ведра - ыцбас, выбегала вниз по склону...).

«Биһиги, оччотооуу кэм оБолоро, бассабыыктар этибит. Баайдары бахтатар, тойоттору тобуктатар ньиргиэрдээх, бойобуой ырыалары түмсэ түһэн, парадтаан, маршынан иһэн ыллыырбыт.» (Mы, дети тех времен, были большевиками. Собравшись вместе и маршируя на параде, мы часто запевали энергичные боевые песни против баев и тойонов!).

«Саргы Сахадова ах барда. Чуумпу. Чыьчаах ырыата иһиллэр, сэбирдэх быыһынан күн толоно кутуллар.. Саргы, тобугуттан тардыстан, сир тыынарын иһиллээн олордо, кини ыраађы да ыраақы, санаа сиппэт ыраађын Сир Халлааны кытта ыпсар сақађын одуулаһар курдук... Онтон эмиэ сыыйа ыллаан барда» (Саргы Сахадова замолчала. Тишина. Слышно пение птии, сквозь листья деревьев просвечивались лучи солниа. Саргы, наклонившись,сидела тихо, как-будто пыталась сльшиать дыхание земли; ее взор устремлен так далеко, куда даже мысль не доходит - а именно туда, где Земля с Небом соприкасается... Потом она опять начала петь).

«Саргы олорбут дүлүнүттэн туран иһэн, атађын анныттан күөх ачаны - дьикти-кэрэ сибэккини булан ылла!.. Иһигэр: «... тыый, Танара кийиитэ!» - диэтэ. Кини «кута ыстанна», долгуйда. Тула көрүннэ, эргичийдэ. Сибэккини уоһугар дақайда» (Саргы нашла прекрасный цзветок. Про себя: «... ой, Танара кийиитэ.». Ее вдруг охватило волнение. Огляделась по сторонам, поднесла иветок к губам).

Как видно из приведенного примера, ремарки становятся неотъемлемой частью повествования. Они помогают понять чувство, настроение героини и 
становятся композиционными связками между песнями-монологами. Как отметил Г.А. Червяченко, одной из главных особенностей драматической поэмы как жанровой формы является особая функция ремарок, а именно приобретение ими роли повествования ${ }^{74}$. Эта особая функция ремарок подтверждается и во второй части поэмы, где ремарка конкретно указывает на место и время происходящих событий. Действие этой части происходит в городе Якутске в конце 1930-х годов. В ремарках дается повествование героини об учебе в медицинском техникуме, участии в общественно-политической работе и занятиях в аэроклубе. Из рассказа Саргы Сахадовой читатель узнает об ее мечте стать врачом. Монолог во второй части поэмы включает в себя шесть отдельных песен (разделение условное), каждая из которых посвящается определенному периоду жизни героини. Первая песня повествует о счастливых, веселых днях, проведенных на занятиях аэроклуба; вторую песню составляют размышления героини о любви; в третьей - поется о том, как ее отца, участника битвы Сасыл Сысыы, объявили «врагом народа»; далее следует песня о прекрасном олене, являющемся, на наш взгляд, символом ее юности. Четвертая и пятая песни повествуют об одиночестве героини, муках и боли, перенесенных в то время, и о надежде встретить человека - Юрюнг Уолана - способного спасти и защитить ее. В конце этой части монолог героини приобретает драматический характер. Вторую часть поэмы, так же как и первую, завершает голос Земли. В этих строках, повторяющихся каждый раз (в конце эпилога, первой и второй частей), автором подчеркивается особый лирикодраматический подтекст в развитии поэтического сюжета о судьбе реальной личности.

Третья часть начинается с ремарки, где сообщается, место действия (местность, где идет война, граница), описывается внешний вид, настроение героини (Саргы Сахадова - военный летчик), раскрывается ее отношение к войне (размышления о войне). Значительно то, что в третьей части поэмы голос Земли вступает в прямой диалог с героиней. Саргы Сахадова рассказывает о том, как она участвовала в войне, была в плену, как одержали победу над врагом. Далее она поет о том, как радость победы омрачили подозрения, недоверие со стороны властей, и как потом ей помогли друзья вернуть честь и совесть, и, наконец, как она обрела счастье в семье, исполнилась ее мечта. Все это время голос Земли как бы поддерживает диалог, проявляет интерес, это передается краткими репликами и возгласами: «һоo, чахчы эбит дии / Билиэннэ түбэспитин?!.» (Оо, правда, оказывается, / Что в плен попала?!), «Һоо! Оо дьэ!..» (Оо! ну!..), «һоо!. Дьэ онтон?..» (Оо! Ну а потом?..). А в

\footnotetext{
${ }^{74}$ Червяченко Г.А. Поэма в советской литературе. - Ростов-на-Дону: Изд-во Рост. ун-та, 1978. - С. $159-163$.
} 
конце этой части голос Земли произносит следующие слова: «Оо, уруй! Уруй! Уруй!», выражая свою радость и гордость ее гражданским подвигом.

В эпилоге на первый план выводится голос Земли. В его монологе, состоящем из 16 строк, говорится, что отец Саргы Сахадовой реабилитирован, а от пропавшего брата остались «незабываемые следы», и родина мать - Сахаада - приветствует свою дочь, нигде и никогда не уронившей честь и имя Человека.

Произведение завершается песней-монологом Великой Туймаады, сопровождаемой пениями птиц, голосами животных, шелестом листьев, трав и звуками волн. И здесь читатель находит конкретизацию времени. Голос Родины Саргы Сахадовой приветствует свою Дочь в наши дни:

«...Yhүс тыһыынча

Үүнэрэ бу кэллэ,

Икки атахтаах

Өйдөнүөн сөп буолла.

Айыы далбардаах

Аан дойду дьыльатын

Алгыс кынаттаах

Ил-эйэ быыһаатын!

Эйэ, Дьол куруук

Баар буоллун, баар буоллун! [с. 59]
...Тысячелетия третьего

Наступление близко,

Двуногому взяться за ум

Настала пора.

Пусть мира судьбу

Окрыленные благословением

Мир и дружба спасут!

Мир и Счастье

Будут всегда, будут всегда!

Таким образом, образ героини раскрывается через самовыражение в ее песнях-монологах. Саргы Сахадова - героический образ, сумевший противостоять сложной политической обстановке 1930-х годов и войне. Героиню не сломили трудности жизни.

Композиционная структура поэмы М. Тимофеева «Возвращение» особенна: произведение целиком состоит из песен-монологов героини, взаимосвязанных между собой авторскими ремарками. Здесь ремарки приобретают роль повествования, они служат своеобразными композиционными связками между песнями-монологами героини и отдельными частями поэмы, сглаживают в развитии сюжета значительные разрывы во времени. Первая часть повествует о детстве героини, место действия - якутский алас, время - лето. Во второй части мы встречаемся с героиней уже в городе Якутске: юная Саргы Сахадова учится в медицинском техникуме, активно участвует в общественной работе, занимается в аэроклубе. А в третьей части автор уводит героиню на поле войны: она - военный летчик. Таким образом, каждая часть произведения повествует об определенном отрезке из жизни героини, причем повествование дается в хронологической последовательности. Отсюда характерный композиционный прием повтора в развитии сюжета о 
судьбе реализуется через образ родины Саргы Сахадовой. Алас в начале поэмы и Великая Туймаада в эпилоге выступают в неразрывном единстве с героиней произведения и несут в себе особый художественный смысл, а именно, образуют духовный лейтмотив ее монологов.

\section{Контрольные вопросы и задания}

1. Определите значение образа Родины-мать в раскрытии идеи поэмы.

2. Сделайте анализ стихотворного строя песен-монологов героини.

3. Какова роль ремарок в поэме «Возвращение»? Сравните особенности использования ремарок в первой и третьей частях.

4. Определите жанр произведения.

\section{Упражнения и задания для СРС}

1. Определите основные функции ремарок в драматическом произведении. Как проявляется авторская позиция в ремарках?

2. Выделите особенности использования ремарок в драматических поэмах.

3. Прочитайте драматические поэмы И. Гоголева «Звучи, набат мира! », И. Егорова «Февронья». Определите специфические функции авторских ремарок в этих произведениях.

4. Определите роль монологов и диалогов героев в произведениях, выделите стиль речи в них.

5. Определите, в чем заключается своеобразие композиционной структуры драматических поэм этих авторов.

\section{Литература}

I.

1. Гоголев И. Ньиргий, ньиргий, эйэ набаата! Драматическай поэма // Хотугу сулус. 1987. - №9. - С.6-32

2. Егоров И. Хобороос. Драматическай поэма - Якутск: Якут. кн. изд-во, 1980. - 96 с. II.

1. Гуляев Н.А.Теория литературы - М.: Высшая школа, 1985. - 271 с.

2. Кайда Л.Г. Композиционный анализ художественного текста: Теория. Методология. Алгоритмы обратной связи. - М.: Флинта, 2000. - 152с

3. Максимова П.В. Жанровая типология якутской поэзии: Вопросы эволюции и классификации форм. - Новосибирск: Наука, 2002. - 255 с.

4. Червяченко Г.А. Поэма в советской литературе. - Ростов-на-Дону: Изд-во Рост. унта, 1978. - 192 с.

5. Проблемы творчества И.М.Гоголева-Кындыл: поэзия, проза, драматургия. - Якутск: Изд-во ИГИ АН РС(Я), 2004. - 192 с. 


\section{3. Особенности композиции драматической поэмы Р. Багатайского «Лунная ночь»}

Драматическая поэма «Ыйдана түүн» («Лунная ночь», 1991) Р. Багатайского посвящена периоду гражданской войны в Якутии. Автор посредством драматизации раскрывает классовые противоречия в их различных проявлениях. Произведение состоит из вступления, двух частей, эпилога. Каждая часть имеет свое название: первая - «Хапсыһыы» («Противоборство»), вторая - «Хатарыллыы» («Закалка»). Своеобразно названы вступление «Киирии-түмүк» (дословно: «вступление-заключение») и эпилог «Түмүккиирии» (также дословно: «заключение-вступление»).

Р. Багатайский своим произведением призывает современного читателя оглянуться назад в прошлое - в первые десятилетия XX века - через осмысление поступков героев понять суть идеи, борьбы и рассуждать о судьбе народа. Во вступлении драматической поэмы читаем:

«...Онно олорбуттара эбитэ үһү

Гражданскай сэриигэ аттарын

дайытан -

Санардыыны өбүгэлэрбит национальнай күүһү

Кылаассабайга икки аны хайытан...

Ол түмүк Саха сиринээђи сорБотун

Бүгүн одон-додон эргиллэн

билсиэьин:

Таппыттара - тугун, сыыспыттара - тоботун

Ырытан, хайдах буоларга

үөрэниэбин...» ${ }^{75}[$ с. 4$]$
Тогда жили, говорят,

Водя коней своих в гражданскую войну -

Недавние предки наши -

силу национальную

Разделив на два классовых лагеря ...

Первая часть драматической поэмы состоит из 11 эпизодов (автор выделил их нумерацией). Здесь повествуется о суровом времени гражданской войны, когда люди разделились на два классовых лагеря: красных и белых. Каждому предстояло сделать выбор - дать предпочтение одному из них. Сюжетное действие драматической поэмы развивается по двум направлениям: первое повествует о жизни людей, представляющих класс большевиков (Дуолан, Долгуу, Чагаан, Олонхолоон), другое - о действиях представителей противоположного класса (Чинэлджийэ, Джагарыма, Авраам, Юргюлджю). Главные герои поэмы Санаа Боотур и Тута Хоодуот имеют особое отношение к

75 Здесь и далее текст дается по изданию: Багатайский Р. Ыйдана түҮн: поэма. - Якутск: Кн. изд-во, 1991. $-96 \mathrm{c}$.

76 Здесь и далее подстрочный перевод наш - Л.Г. 
представителям этих классов. Санаа Боотур против разделения народа на два враждующих класса, и потому советует людям (Долгуу, Дуолан, Юргюлджю и др.) не примыкать ни к красным, ни белым: «бэйэ төбөтүнэн сылдьыахха» (жить нужно по зову разума). Тута Хоодуот, напротив, не видит другого пути в тот момент истории, кроме как по убеждению поддержать борьбу двух идей.

В монологах и диалогах Санаа Боотура и Тута Хоодуота выражаются их идеи, направленные на решение судьбы нации. Конечная цель их программы одинакова: сделать народ свободным. Однако оружие, применяемое для осуществления этой цели, для каждого разное. Для Санаа Боотура - это мирная реформа: образование, культура и дружба с сильными нациями. По мнению Санаа Боотура, борьба приводит к истреблению народа. Для Тута Хоодуота единственным путем для достижения идеи - создания свободного государства является борьба. И потому он становится одним из руководителей движения против большевиков. В первой части, как собственно говорит и само название («Противоборство»), противоборствуют идеи, противоборствуют классы.

Вторая часть автором названа «Закалка», состоит из 12 эпизодов. Здесь и сами герои, и их идеи как бы проходят «закалку» в борьбе. Действие драматической поэмы развивается, как и в первой части, по двум направлениям: первое повествует о жизни Долгуу, Чагаан, Олонхолоон и девушки Тырыбынай, каждый из них своей работой, своими поступками пытается помочь новой власти. Второе - о подготовке белых к вооруженному восстанию. В центре внимания оказываются Юргюлджю, Чинэлджийэ, Отец Авраам и некоторые другие персонажи. Читатель узнает о трагической гибели Тута Хоодуота: он был убит человеком по имени Кырбый Харах. В сюжете поэмы видное место занимает повествование о действиях «печника» Осипа, красного чекиста, с помощью которого происходит задержание организаторов восстания. В конце 11-го эпизода Олонхолоон и Чагаан говорят, что теперь исполнению их мечты построить собственный дом никто и ничто уже не может помешать. Последний 12-й эпизод второй части составляют завещание (кэриэс сурук) Тута Хоодуота и монолог Санаа Боотура.

В эпилоге кратко повествуется о дальнейшей судьбе героев поэмы. Главный акцент делается на представителе нового поколения Нюргуне: автор дает ему право завершить произведение монологом, полным оптимизма и надежды:

«Эрэнэн күүтүөБүн

Санаа Боотурдар көрүүлэригэр

Сана хотойуктар үүнэн тахсыахтарын!

Холобур оноһуннуннар кэлэр

көлүөнэлэр
С надеждой будем ждать

Появления новых орлов на воззрениях Санаа Боотуров!

Пусть примером будут для будущих поколений 
Санаа Боотурдар кырдыыктарын, сылыктарын!...

Бүгүннү олох - түмүк буолбатах, Дьыдқабыт сана кэрдиис кэмигэр дьэ киирдибит.

Норуот быһыытынан сүтүмээри, урут туолбатах

Ба5а санааларбытын, дьэ, кынаттыы тиирдибит!..» [с. 94]
Правда и идея Санаа Боотуров!...

Сегодняшняя жизнь - это не итог,

На новую ступень судьбы своей вступили мы.

Чтобы не исчезнуть как народ, как нация

Неисполненные ранее мечты свои как крылья распахнули мы!...

В композиционном отношении поэма Р. Багатайского «Лунная ночь» имеет свои особенности. Произведение четко разделено на две части, которые, в свою очередь, разбиты на несколько эпизодов. Каждый новый эпизод снабжен авторскими ремарками, которые даются в виде стихов, состоящих из четырех и более строк: в них сообщаются время и место происходящих событий, описываются действия героев. Рассмотрим, для примера, ремарки первой части:

\section{1}

Тыа сирин дьаданылара

Танастыын мара-сара,

Олонхолоонноох Чақаан

Ойуурга мас кэрдинээри кээлтэр...[с.5] 2

Дьақарыма Даарыйа

Дьалхааннаах киэн уоруга.

Үргүлдьүнү ыалдьыттаан,

Үөрдэ-көтүтэ олорор...[c.10]

3

Куораттаађы учууталыгар,

Костина Вера ПетровнаБа,

Долгуу сурук суруйар:

Нуучча санас аламақай

Сыhыанын махтана өйдүүр,

Сылаанньыйа ахтар-саныыр...[с.11]

$$
4
$$

Гражданскай сэрии сақана,

Киэһэ Долгуу дьиэтигэр

Кинигэ аақа олордоқуна,

Тута Хоодуот киирэн кэлэр...[c.16]

$$
5
$$

Дьақарыма дьиэтэ дьалхаан,

Үрүн ыстааба буолан турар.

Хаартыһыт Үргүлдьүнү хайБаан,

Тута Хоодуот санныга

таптайар...[c.18]
Сельские бедняки

В старой и плохой одежде своей,

Олонхолоон и Чагаан,

Пришли в лес рубить деревья...

Просторный дом

Дарии Джагарыма.

Устроила она радужный прием

Гостю своему Юргюлджю

Долгуу пишет письмо

Своей учительнице

Вере Петровне Костиной в город:

Она благодарна ей, русской женщине,

За доброе к ней отношение...

Во время гражданской войны,

Когда Долгуу дома вечером

Сидела за чтением,

Заходит Тута Хоодуот...

В доме Джагарыма людно и шумно,

Здесь теперь - штаб белых.

Довольный картежником Юргюлджю, Тута Хоодуот хлопает его за плечи ... 
Тута Хоодуот остуолга

Туох эрэ суругу ааБар.

Ол кэмнэ Үргүлдьү киирэр,

Олус өрүкүйбүт көрүннээх...[с.23]
За столом Тута Хоодуот

Письмо какое-то читает.

В тот момент заходит Юргюлджю,

Вид у него взволнованный...

В седьмом эпизоде нет ремарки, он целиком состоит из монолога Санаа Боотура.

8

Гражданскай сэрии маннайгы

Кытаанах кэмэ ааспыт.

Советскайдыы быһыы-майгы

Сириэдийбит курдук буолбут...

Олонхолоон өрөпкүөм, Чақаан сэбиэт

Сугулаанна үлэлии олороллор:

Улуус киинин дьаһалыгар

Субуотка суруйаллар...[с.29]

9

АмнистияБа хабыллан, Араас киһи быыһаммыт.

Тута Хоодуот, онно кыбыллан, Тутуллууттан ордубут.

Санаа Боотур да онуоха үтүөлээБэ,

СалалтаБа мэктиэлээбитэ...[с.31]

10

Сана олох күүрээнигэр

Долгуу үлэнэн үлүһүйэр,

Тырыбынайга да үөрэқирэр

Тыргыл суолу ыйан биэрэр ...[с.35]

11

Тута Хоодуот дьиэтэ. Киниэхэ кэлбит

Санаа Боотурдуун мөккүһэллэр:

Дьыльа, норуот тустарынан

Санааларын үллэстэллэр ...[с.37]
Первые суровые годы

Гражданской войны прошли.

В жизни теперь как будто

Наладилось все по-советски...

Олонхолоон теперь ревком,

а Чагаан - совет.

Сидят они в конторе за работой:

Для улусной администрации

Они пишут сводку ...

Попав под амнистию, Были спасены многие люди.

Был освобожден и Тута Хоодуот.

В этом имеется и заслуга Санаа Боотура

За него перед управлением ручался...

В разгаре новой жизни

Долгуу работает неустанно, Обучает Тырыбынай,

Светлую ей дорогу указывает она...

Дом Тута Хоодуота. С прибывшим к нему

Санаа Боотуром спорят они:

О судьбе и народе

Обмениваются мнениями они...

Диалоги и монологи персонажей часто сопровождаются краткими ремарками, указывающими на эмоциональное состояние говорящего: «оонньуу былаастаан» (играя), «долгуйбутун кыатанан» (не показывая своего волнения), «кыыһыран тахсан барар» (рассердившись, уходит), «сөбүлэһэр быһыынан» (демонстрируя согласие), «санаарқаабыттык» (тоскливо), «сирэйэ сырдыыр» (радуется) и т.д. Как видно из приведенных примеров, ремарки не только выполняют функцию информирования о происходящих событиях и действиях 
героев, но и являются неотъемлемой частью повествования, что свойственно жанру драматической поэмы. Ведь в ней сюжетное действие имеет свободное перемещение, как во времени, так и в пространстве, чем и обуславливается необходимость авторских ремарок.

В драматической поэме увеличивается роль монологов, где, главным образом, «обнажаются идеи». Функция диалогов и реплик в определенной степени снижается. Однако следует отметить, что диалог между основными героями - Санаа Боотуром и Тута Хоодуотом - тяготеет к монологической форме. В поэме автор сталкивает в диалоге Санаа Боотура с Тута Хоодуотом только один раз - в конце первой части поэмы (11 эпизод). В своих высказываниях герои излагают главные идеи. И потому разговор между ними приобретает особую функцию: излагать противоборствующие идеи. Герои находятся в том высшем состоянии драматизма, которое требует не только содержательной полноты высказывания, но и особой его эмоциональной выразительности. Язык персонажей не индивидуализирован. Эмоциональная выразительность, обобщенно-поэтический смысл каждого высказывания воспринимаются как направление художественной идеи поэмы, а не как характеристика образов.

В системе образов видное место занимают образы Санаа Боотура и Тута Хоодуота, в которых угадываются реальные исторические личности. В постановке проблемы глубокого социального звучания и обращении к конкретному историческому периоду жизни общества читатель может представить в их образах, например, А.Е. Кулаковского, А.И. Софронова (Санаа Боотур) или видных народных лидеров коммунистической ориентации (Тута Хоодуот), т.е. исторический материал и национально-философская идея тяготеют к реальной исходной ситуации, что является закономерностью для жанровой природы драматической поэмы ${ }^{77}$.

Если Тута Хоодуот имеет непосредственное отношение к одному из противоборствующих классов, то Санаа Боотур, согласно своей идеи, придерживается нейтрального положения. Санаа Боотур призывает людей, независимо от их политической ориентации, прислушаться к его словам. Например, Юргюлджю, который ради личной выгоды готов на самые разные поступки, говорит:

«Саха өйдөөБө Санаа Боотур

Саамай сөпкө сэрэппитэ:

«Кыһыл да, үрүн да диэки
Умный из саха Санаа Боотур

Правильно меня предупредил:

«Ни за красных, ни за белых

77 Максимова П.В. Жанровая типология якутской поэзии: Вопросы эволюции и классификации форм. Новосибирск: Наука, 2002. - С.214-215 
Кыргыһыыга кыттыма!» - диэн эппитин Ылынан сылдьабын» [с.68]
Не участвуй в борьбе!».

И я решил прислушаться его словам.

Или, например, Джагарыма боится, что Санаа Боотур может убедить Тута Хоодуота отказаться от борьбы: «Оо, Санаа Боотур обургу, / Ол киһини кини булкуйбута буолаарай? / «Кыһыллары кыйахааман, / Кыайбат аата кыргыллыман!» - диэн / Эйиэхэ да, миэхэ да / Элэ-была тылын эппитин билэбин» [c.70-71] («Оо, Санаа Боотур / Может того человека он убедил? / «Не трогайте красных, / Зная неминуемое поражение, не боритесь, будете истреблены» / Знаешь сам, так говорил он и тебе, и мне»). Мы находим мысли Санаа Боотура также в словах Долгуу: «Үөрэхтээх киһи өлөн-охтон биэрбэт» [c.35] (образованный человек никогда не пропадет), «Өргөстөөх тылынан, / Өһүөннээх санаанан буолбакка, / Үтүө сыһыанынан, / Үүммүт сана былааһы дьонно / Өйдөтүөхтээх, өйүөхтээх сыалбытын / Өрүүтүн өйдөөн сырыт» [c.43] (Не острыми словами, / Не вражескими мыслями, / А своим хорошим отношением, / Наступившую новую власть людям / Должны мы объяснить, поддержать их. / Не забывай об этом никогда). Или таково обращение Тута Хоодуота к Санаа Боотуру в своем завещательном письме:

«Ыраах энсиилээх санаађын сөпсөөн, Ытыктаан кэлбит үтүө киһим, Сыллары курдат сылыктыырын иһин Санаа Боотур диэн дьон таптаан ааттаабыт Дирин хорутуу доборум, Дьэ эрэ, дорообо буоллун!..» [с.83]
Принимая далеко идущие мысли твои, Уважал тебя, добрый мой друг,

За то, что мыслишь далеко вперед Назвали тебя люди, Санаа Боотуром.

Глубокий мой друг,

Здравствуй, говорю тебе!..

Как видно, для раскрытия образа Санаа Боотура задействованы почти все персонажи. Санаа Боотур характеризуется ими как носитель идеи мира.

Вокруг образа Тута Хоодуота группируются персонажи, относящиеся к белым: князь Чинэлджийэ, Джагарыма, Отец Авраам, Юргюлджю и некоторые другие. Свидетельством того, что идея Тута Хоодуота обречена на провал, выступают сложные взаимоотношения между членами группировки. Например, читателю известна позиция Юргюлджю, активно участвующего в делах белых. А из монолога Тута Хоодуота читатель узнает о том, что князь Чинэлджийэ и Отец Авраам пытаются уговорить Юргюлджю, выдать его властям. О чем, непосредственно, Тута Хоодуот узнает от Джагарыма. Как видно, образуется некая цепочка. В конечном итоге эта цепочка обрывается: Тута Хоодуот погибает от рук предателя - Кырбый Харах. Особую смысловую нагрузку несет эпизод, где автор описывает сон убийцы. Кырбый Хараху снится, будто Тута Хоодуот не погиб, и он снова пытается его пристрелить. На наш взгляд, автор 
этим хотел сказать о бессмертности идеи Тута Хоодуота. Нужно подчеркнуть, что каждая сцена в поэме - это обращение к читателю. Каждый эпизодический персонаж (например, Кырбый Харах) имеет решающее значение в понимании отношений между отдельными героями поэмы, а также в развитии главных событий.

Трагическая судьба Тута Хоодуота напоминает героя из драматической поэмы литовского поэта Ю. Марцинкявичюса «Миндаугас». Так же как и Миндаугас, который стремился создать могущественную и сильную Литву, Тута Хоодуот борется за создание отдельного государства Саха. За исполнение своей идеи они оба не останавливаются ни перед чем. Как не слушал своего брата Дауспрунгаса Миндаугас, так и Тута Хоодуот не хочет слушать и понять Санаа Боотура. Аналогична и смерть Тута Хоодуота - он был убит, как и Миндаугас, рукой «свояка». Указывая на некоторые аналогии, мы еще раз убеждаемся в том, что в драматической поэме авторы всегда сосредоточиваются на сильных, ярких натурах, проявляющих себя в общественно значимых поступках, в важнейших событиях национальной истории. Герои поэмы находятся в критической, напряженной ситуации, что приводит к столкновению идейных позиций.

На фоне основных героев другие персонажи драматической поэмы в их образных обобщениях выступают намного шире и объемнее своего исторического времени. В них автор воплотил поэтический образ народа, испытывающего на себе действия общественных закономерностей. Как отметила П.В. Максимова, некоторые из персонажей поэмы в своих частных, «личных» стремлениях и поведении вполне могут быть восприняты людьми и нашего поколения. «С одной стороны, это и есть поэмное начало: эпикодраматическая идея произведения, реализующая жанровые поиски поэмы от одноплановости к полифонизму и многомерности содержания, - заключает исследователь. - С другой стороны, это может быть творческой удачей автора: поэт раскрывает глубинное переплетение, перекличку судеб, времен, противостояний» ${ }^{78}$.

Таким образом, в драматической поэме Р. Багатайского «Лунная ночь делается сознательная сосредоточенность на главных героях и их идее, чем обусловлены особенности композиционной структуры произведения: уход на второй план внешней характеристики жизни персонажей; увеличение роли монологов, снижение функции диалогов и реплик, включенность в повествование авторских ремарок. Однако главное отличие поэмы Р. Багатайского заключается в реально-историческом подтексте содержания.

\footnotetext{
${ }^{78}$ Максимова П.В. Указ. соч. - С. 215
} 
Здесь каждый персонаж символичен, главным образом, в укрупненном выражении социальной идеи в их историческом ракурсе. В этом плане «Лунная ночь» более сценична, чем другие рассмотренные нами произведения. И потому особенности композиции определены систематизацией персонажей, где эпизодические образы так же значительны, как и образы носителей главных противопоставленных идей (Санаа Боотур и Тута Хоодуот). Именно данная последовательная систематика образов составляет композиционный ход размышлений автора о трагических годах гражданской войны.

\section{Контрольные вопросы и задания}

1. Какова роль авторских отступлений в развитии сюжета поэмы?

2. Определите идею произведения на основе анализа монологов Санаа Боотура и Тута Ходуота.

3. Определите роль и функции эпизодических персонажей поэмы.

4. Какое композиционное значение имеют вступление и эпилог произведения?

\section{Упражнения и задания для СРС}

1. Прочитайте драматическую поэму литовского поэта Ю. Марцинкявичюса «Миндаугас».

2. Сравните образ главного героя Миндаугаса с героем поэмы Р. Багатайского «Лунная ночь» Тута Хоодуотом. В чем заключается идея каждого из них?

3. Прочитайте поэму Р. Багатайского «Ксенофонтовщина или расстрелянная мечта». Определите жанровую форму произведения.

4. В чем роль и художественные функции цитат из работ Г.П.Башарина, Е.Е.Алексеева, отрывков из архивных и документальных материалов, включенных в сюжет поэмы «Ксенофонтовщина или расстрелянная мечта»?

5. Определите опорные точки композиции поэмы «Ксенофонтовщина или расстрелянная мечта», дайте характеристику основных композиционных приемов.

6. На основе особенностей организации текста сделайте характеристику места и роли автора в поэмах «Лунная ночь» и «Ксенофонтовщина или расстрелянная мечта». 


\section{Литература}

I.

1. Марцинкявичюс Ю. Миндаугас. Драма-поэма в 2-х ч. Пер. с литов. А.Межирова. Вильнюс: «Вага», 1973. - 151 с.

2. Ба5атаайыскай P. Ксенофонтовщина эбэтэр Ытыллыбыт ыра // БаБатаайыскай Р. Сүгүрүйүу: поэмалар. - Якутск: Бичик, 2001.

II.

1. Гуринов А.Г.- Арчылан. Хотойуктар тахсыахтара // Сахаада. - 1993. - 25 июня.

2. Ланкутис Й. Поэтический мир Юстинаса Марцинкявичюса. Очерк творчества. - М.: Советский писатель, 1980. - 248 с.

3. Марцинкявичюс Ю. Судьбы поэм // Вопросы литературы. - 1966.- №10. - С. 144151.

4. Мирошниченко Л.П. Функциональная роль драматической поэмы в советской поэзии 60-80 гг. // Проблемы литературных жанров: сб. тез. докл. - Томск, 1990. - С. 178-179.

5. Успенский Б.А. Поэтика композиции. - СПб.: Азбука, 2000. - 352 с. 
Учебное издание

Максимова Прасковья Васильевна, Григорвева Людмила Павловна

КОМПОЗИЦИОННЫЙ АНАЛИЗ ПОЭМЫ

(на материале якутской литературы)

Учебное пособие

Издается в авторской редакции

Подписано в печать 28.02.2014. Формат 60x 84/8.

Печ. л. 13,25. Уч.-изд. л. 16,56. Электронное издание. Заказ № 82.

Издательский дом Северо-Восточного федерального университета

677891, г. Якутск, ул. Петровского, 5.

Изготовлено в ИД СВФУ 